\title{
GEOLOGICAL SURVEY OF CANADA RADIOCARBON DATES XI
}

\author{
J. A. LOWDON, I. M. ROBERTSON, and W. BLAKE, JR.*
}

Division of Quaternary Research and Geomorphology

Geological Survey of Canada, Ottawa 4, Canada

\section{INTRODUCTION}

During the past year, 1969-1970, both the 2-L (Dyck and Fyles, 1962) and 5-L (Dyck et al., 1965) counters were routinely operated. A 1-L counter was finally constructed with acceptable characteristics (see description below) and was operated in July in place of the 5-L counter. The 2- $\mathrm{L}$ counter was operated exclusively at $2 \mathrm{~atm}$. The 5- $\mathrm{L}$ counter was operated at $1 \mathrm{~atm}$, except for October and November, 1969, when it was operated at $4 \mathrm{~atm}$. The 1-L counter was operated at $1 \mathrm{~atm}$.

After six unsuccessful attempts to construct a 1-L counter with an acceptably low background, one was finally fabricated and put into operation in June, 1970. The basic design of the counter is the same as for the 2-L counter described previously (Dyck and Fyles, 1962). A copper tube 181/4" long, $21 / 8^{\prime \prime}$ O.D. with an $1 / 8$ " wall was used for the counter. In an attempt to ensure a low background, 0.03" was machined from both inner and outer surfaces. Just prior to assembly, the tube and copper end plates were dipped in $30 \%$ nitric acid, then rinsed with distilled water and acetone. The copper end plates and quartz insulators were glued in place using Waldor 810 adhesive. The R-C network and coupling capacitor were placed in a separate ground box to simplify the initial selection of values. The more important counting characteristics of the 1-L counter are given in Table 1.

During its first month of operation, July 1970, 4 background samples and 3 oxalic acid standards were counted. The average background counting rate was $1.375 \pm .026$ and the standard $4.391 \pm .051$.

Table 2 lists a comparison of results obtained from different counters. All samples were given two 1-day counts except for GSC-1361 in which each result was based on one 3-day count. The figures in parentheses are the uncorrected ages of the samples for which $\delta \mathrm{C}^{13}$ values are given.

Age calculations are carried out monthly by a C.D.C. 3100 computer and are based on a $\mathrm{C}^{14}$ half-life of $5568 \pm 30 \mathrm{yr}$ and 0.95 of the activity of the NBS oxalic acid standard. Ages are quoted in years before present (в.P.), where "present" is taken to be 1950. Age errors include: counting errors of sample, background, and standard; error in the half-life of $\mathrm{C}^{14}$; and an error term to account for the average variation of $\pm 1.5 \%$ in the $\mathrm{C}^{14}$ concentration of the atmosphere during the past $1100 \mathrm{yr}$. The error assigned to an age is always a minimum of \pm 100 yr. Unless otherwise stated in the sample descriptions, all ages are based on two

* The introduction has been prepared by the first author, who operates the laboratory. The description and testing of the new l-L counter has been the responsibility of the second author. The date list has been compiled by the third author from descriptions of samples and interpretations of dates by the collectors. 
TABLE 1

\section{1-L Counter Characteristics}

\begin{tabular}{|c|c|c|c|c|c|c|c|c|}
\hline $\begin{array}{c}\text { Volume* } \\
\text { (liters) }\end{array}$ & $\begin{array}{l}\text { Oper. } \\
\text { press. } \\
(\mathrm{atm})\end{array}$ & $\begin{array}{c}\text { Oper. } \\
\text { volt. } \\
\text { (K.V.) }\end{array}$ & $\begin{array}{l}\text { Back- } \\
\text { ground, B } \\
(\mathrm{c} / \mathrm{m})\end{array}$ & $\begin{array}{c}\text { Standard } \\
\mathrm{N}_{\mathrm{O}} \\
(\mathrm{c} / \mathrm{m})\end{array}$ & $\begin{array}{l}\text { Figure } \\
\text { of } \\
\text { merit** }\end{array}$ & $\begin{array}{c}\text { Meson } \\
(\mathrm{c} / \mathrm{m})\end{array}$ & $\begin{array}{r}\begin{array}{r}\text { Platea } \\
\text { slopes }\end{array} \\
\text { Meson }\end{array}$ & $\frac{\mathrm{au}}{\mathrm{s}^{14}}$ \\
\hline $\begin{array}{c}0.91 \\
(0.84)\end{array}$ & 1.0 & 3.9 & $1.38 \pm .03$ & $4.39 \pm .05$ & 3.12 & 101.2 & 0.3 & 1.4 \\
\hline
\end{tabular}

* The values in brackets is the sensitive volume of the counter, i.e., the volume between the anode sleeves.

** The figure of merit is calculated from the expression,

Figure of Merit $=\mathrm{C} \times \mathrm{V} \times \frac{\mathrm{N}_{\mathrm{o}}}{\sqrt{\mathrm{B}}}$ where

$\mathrm{C}=$ counting efficiency $=.90$ (estimated)

$\mathrm{V}=$ volume efficiency $=\frac{\text { sensitive volume }}{\text { total volume }}=.92$

$\mathrm{N}_{0}=0.95 \times$ net counting rate of the NBS oxalic acid standard

$\mathrm{B}=$ background counting rate

+ The plateau slopes are expressed in $\%$ per 100 volts and were measured over a 200 volt interval.

Meson $=$ total rate - (sample + background rate $)$

$\mathrm{C}^{14}=$ oxalic acid standard + background

TABLE 2

Comparison of Results from Different Counters

\begin{tabular}{lcccc}
\hline $\begin{array}{l}\text { Sample } \\
\text { no. }\end{array}$ & $\begin{array}{c}\delta \mathrm{C}^{13} \\
(\% \circ)\end{array}$ & $\begin{array}{c}\text { 1-L } \\
(1 \mathrm{~atm})\end{array}$ & $\begin{array}{c}2-\mathrm{L} \\
(2 \mathrm{~atm})\end{array}$ & $\begin{array}{c}5-\mathrm{L} \\
(1 \mathrm{~atm})\end{array}$ \\
\hline GSC-1344 & & $13,200 \pm 420$ & $13,000 \pm 290$ & \\
GSC-1345 & & $(6290 \pm 250)$ & $(6450 \pm 150)$ & $(6340 \pm 140)$ \\
& -22.0 & $6340 \pm 250$ & $6500 \pm 150$ & $6390 \pm 140$ \\
GSC-1353 & & $10,600 \pm 380$ & $10,700 \pm 310$ & \\
GSC-1361 & & $(570 \pm 180)$ & $(410 \pm 160)$ & \\
& -22.2 & $620 \pm 180$ & $460 \pm 160$ & \\
\hline
\end{tabular}

* Detailed description of GSC-1345, an inter-laboratory check sample of wood from Svalbard, appears in this date list. All others are deferred to a later list.

1-day counts. Finite dates are based on the $2 \sigma$ criterion $(95.5 \%$ probability) and "infinite" dates on the $4 \sigma$ criterion $(99.9 \%$ probability).

Average background and standard counting rates over the past 12 months are listed in Tables 3 and 4, respectively.

The 2-L monthly backgrounds are the average of 4 individual daily counts. During the year, one count was omitted for statistical reasons and 9 different background preparations were used. At 4 atm, OctoberNovember, the 5-L background is the average of 11 individual daily counts. No results were omitted and 3 preparations were used. At 1 atm the 5-L monthly backgrounds are the average of 4 individual daily counts. No counts were omitted and 4 preparations were used. 
For the 2-L counter, the monthly standards are the average of 3 individual daily counts. Four oxalic acid preparations were used and no count had to be omitted. At 1 atm the monthly 5-L standard counting rate is the average of 3 individual daily counts. No counts were omitted and 3 different preparations used. At 4 atm, the standard counting rate is the average of 6 daily counts. No counts were omitted and the same oxalic acid preparation was used.

TABle 3

Monthly Background (c/m) for Period

October 1, 1969 to September 30, 1970

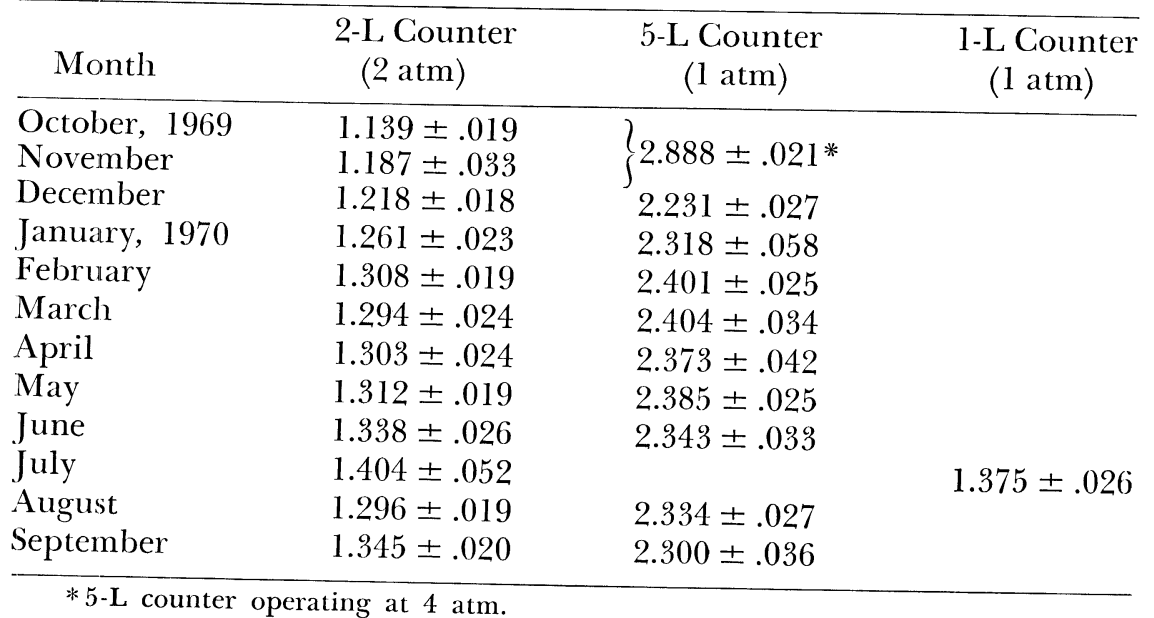

\section{TABle 4}

Monthly Standard, $\mathrm{N}_{\mathrm{O}}{ }^{*}(\mathrm{c} / \mathrm{m})$ for Period

October 1, 1969 to September 30, 1970

\begin{tabular}{lccc}
\hline \multicolumn{1}{c}{ Month } & $\begin{array}{c}\text { 2-L Counter } \\
(2 \mathrm{~atm})\end{array}$ & $\begin{array}{c}\text { 5-L Counter } \\
(1 \mathrm{~atm})\end{array}$ & $\begin{array}{c}\text { 1-L Counter } \\
(1 \mathrm{~atm})\end{array}$ \\
\hline October, 1969 & $19.473 \pm .095$ & 112.021 $\pm .186 * *$ & \\
November & $19.569 \pm .154$ & $28.412 \pm .168$ & \\
December & $19.706 \pm .095$ & $28.606 \pm .127$ & \\
January, 1970 & $19.591 \pm .096$ & $28.700 \pm .195$ & \\
February & $19.668 \pm .094$ & $28.620 \pm .163$ & \\
March & $19.690 \pm .128$ & $28.718 \pm .133$ & \\
April & $19.652 \pm .137$ & $28.787 \pm .129$ & \\
May & $19.635 \pm .095$ & $28.525 \pm .123$ & \\
June & $19.651 \pm .110$ & & $4.391 \pm .051$ \\
July & $19.478 \pm .108$ & $28.823 \pm .121$ & \\
August & $19.712 \pm .106$ & $28.889 \pm .120$ & \\
September & $19.578 \pm .094$ & & \\
\hline
\end{tabular}

$* \mathrm{~N}_{0}=0.95 \times$ net counting rate of the NBS oxalic acid standard.

** 5-L counter operating at 4 atm. 
No changes have been made in the routine $\mathrm{CO}_{2}$ preparation and purification techniques described in previous GSC date lists (Lowdon ct al., 1969; Lowdon and Blake, 1970). However, a new method for the preparation of $\mathrm{CO}_{2}$ from bone samples has been attempted. In the past, much time and effort has been spent in purifying the $\mathrm{CO}_{2}$ gas from bone (collagen) samples. The excess impurities are due, in most part, to the presence of nitrogen compounds which are not readily removed in the purification train. Whereas a typical $\mathrm{CO}_{2}$ sample from wood, charcoal, peat, or shell requires only from 2 to 4 passes through the hot $\mathrm{Cu}-\mathrm{Ag}$ wool furnace $\left(850^{\circ} \mathrm{F}\right)$, bone samples have required up to 20 passes to achieve the purity required for necessary counting efficiency. It is hoped that this purification problem can be overcome by using the "precipitation" method described below.

Combustion of the bone collagen is carried out in the manner previously described (Lowdon et al., 1969). The $\mathrm{CO}_{2}$ evolved is then passed through dilute $(50 \%) \mathrm{H}_{2} \mathrm{SO}_{4}$ to remove water of combustion, then through 2 traps containing $500 \mathrm{ml}$ each of $3 \mathrm{~N} \mathrm{NH} \mathrm{NH}_{4} \mathrm{OH}$. The $\mathrm{CO}_{2}$ is absorbed in this solution, and the remaining gases pass through dilute $\mathrm{H}_{2} \mathrm{SO}_{4}$ to absorb $\mathrm{NH}_{3}$ fumes. By addition of $\mathrm{SrCl}$ to the $\mathrm{NH}_{4} \mathrm{OH}$ traps, $\mathrm{SrCO}_{3}$ is precipitated. $\mathrm{CO}_{2}$ is then liberated by the action of phosphoric acid. The 2 samples so far prepared by this method required only minimal purification. The main concern with this method is the risk of atmospheric $\mathrm{CO}_{2}$ being absorbed in the $\mathrm{NH}_{4} \mathrm{OH}$ solution. To eliminate this, the $\mathrm{NH}_{4} \mathrm{OH}$ solution was prepared, and the $\mathrm{SrCO}_{3}$ precipitation carried out, in a plastic glove bag filled to a positive pressure with ultra-pure nitrogen. By the use of rubber hose connections and clamps, the $\mathrm{NH}_{4} \mathrm{OH}$ solution was never exposed to the atmosphere. Table 5 compares the results obtained on the 2 samples prepared by our standard and new precipitation methods. The results agree within statistical limits showing that atmospheric contamination is negligible. The $\delta \mathrm{C}^{13}$ results indicate that little, or no, fractionation has occurred in the laboratory process. Additional samples will be processed by both methods before the method described above is accepted as standard procedure in this laboratory.

In this date list, where $\delta \mathrm{C}^{13}$ measurements are available, a correction for isotopic fractionation has been applied to the date,* and the $\delta \mathrm{C}^{13}$ value reported. Related to the PDB standard, the normal value used for correction is $\delta^{13}=-25.0 \%$ for all organic materials (including bones) and $0.0 \%$ for marine shells. The $\mathrm{C}^{13} / \mathrm{C}^{12}$ ratios reported were determined by either Isotopes Inc., New Jersey, or the GSC Geochronology Section (Head, R. K. Wanless), on aliquots of the same sample gas used for age determination.

\section{ACKNOWLEDGMENTS}

Thanks are extended to the following personnel: Mrs. S. Chartrand

* Except for terrestrial and fresh-water shells, for which the initial $\mathrm{C}^{14}$ content is unknown. 
and D. Hodgkin for assistance in the preparation and measurement of samples in the laboratory; Miss G. Minning for assistance in compilation of the date list; K. Santowski for the GSC $\delta \mathrm{C}^{13}$ determinations; Mrs. P. Spratt for typing the manuscript; and K. Shimizu and Mrs. M. Patterson for assistance in converting all units to the metric system. The 1-L counter was fabricated in the GSC Instrumental Development Shop by G. A. Meilleur.

TABLE 5

Comparison of Results on Bone Samples By Different Preparation Techniques

\begin{tabular}{llcrr}
\hline Sample no. & Procedure & $\begin{array}{c}\text { Uncorrected } \\
\text { age (yr B.P.) }\end{array}$ & $\begin{array}{c}\delta \mathrm{C}^{13} \\
\% \text { \%o }\end{array}$ & $\begin{array}{r}\text { Corrected } \\
\text { age (yr B.P.) }\end{array}$ \\
\hline GSC-1219 & Standard & $2260 \pm 130$ & -21.2 & $2320 \pm 130$ \\
GSC-1219-2 & SrCO $_{3}$ & $2210 \pm 130$ & -21.2 & $2270 \pm 130$ \\
GSC-1220 & Standard $_{\text {GSC-1220-2 }}$ & $31,900 \pm 630$ & -18.7 & $32,000 \pm 630$ \\
& SrCO $_{3}$ & $31,600 \pm 690$ & -19.8 & $31,700 \pm 690$ \\
\hline
\end{tabular}

* Detailed description of GSC-1220 is deferred to a later date list. Description of GSC-1219 appeared in Lowdon et al., 1970. Basal peat from the same level as GSC1219 gave an age of $2330 \pm 130 \mathrm{yr}$ (GSC-1308, corrected age; $\delta \mathrm{C}^{13}=-24.9 \%$ ); description of date will appear in a future list.

\section{SAMPLE DESCRIPTIONS}

I. GEOLOGIC SAMPLES

1. Newfoundland

\section{A. Eastern Canada}

\section{GSC-1413 Peter's River}

$3600 \pm 130$ 1650 B.C.

Basal peat (dominated by Eriophorum sp., id. by M. Kuc) from 1.8 $m$ thick deposit in kettle in gravel capping a kame-moraine, truncated by wave-cut cliff, off Hwy. $36,1.6 \mathrm{~km} \mathrm{~N}$ of Peter's River settlement, St. Mary's Bay, Avalon Peninsula, Newfoundland $\left(46^{\circ} 46.7^{\prime} \mathrm{N}\right.$ Lat, $53^{\circ} 37.4^{\prime}$ W Long), alt ca. $15 \mathrm{~m}$. Coll. 1969 by D. R. Grant and V. K. Prest.* Comment (D.R.G.): it was hoped basal peat would date recession of late ice cap on Avalon Peninsula (Henderson, 1960), especially in view of tundra aspect indicated by high proportion of non-arboreal pollen (J. B. Railton, Dalhousie Univ., Halifax, written commun.). Date can, however, be explained in terms of long delay before onset of organic accumulation due to previous substrate. Moreover, region today still cannot support trees owing to exposure and severe climate. $\mathrm{NaOH}$-leach omitted from sample pretreatment. (One 3-day count.)

\section{Ten Mile Lake series}

Marine shells from till and postglacial beach gravel in vicinity of

** All persons referred to as collectors or submitters of samples or otherwise cited as sources of data are with the Geological Survey of Canada unless otherwise specified. 
Ten Mile Lake, Newfoundland. All samples at alt ca. 60 m. Coll. 1969 by D. R. Grant.
GSC-1277. Ten Mile Lake, moraine, Mya truncata

\author{
$10,900 \pm 160$ \\ 8950 B.C. \\ $\delta C^{13}=+1.7 \%$
}

Whole shells and fragments (Mya truncata) from till of end moraine crossing $\mathrm{S}$ end of Ten Mile Lake, Newfoundland $\left(51^{\circ} 04.87^{\prime} \mathrm{N}\right.$ Lat, $56^{\circ} 42.63^{\prime} \mathrm{W}$ Long). Sample from clean face in wave-cut cliff 6 to $9 \mathrm{~m}$ high on peninsula comprising end moraine.

\title{
GSC-1324. Ten Mile Lake, moraine, Balanus $\quad 9050 \pm 160$
}

Barnacle fragments (Balanus sp.) occurring as large angular masses in till of end moraine, same location as GSG-1277.

\section{GSC-1270. Ten Mile Lake, beach, Mya truncat

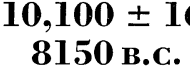$$
\delta C^{13}=+2.6 \%
$$

Shells (Mya truncata), intact and in situ (1 valve from each of 2 pairs subm.), in beach gravel, near top of $6 \mathrm{~m}$ high bank, exposed on $\mathrm{W}$ side of Ten Mile Lake ( $51^{\circ} 03.85^{\prime} \mathrm{N}^{\circ}$ Lat, $56^{\circ} 45.00^{\prime} \mathrm{W}$ Long). Sample from $2.6 \mathrm{~km}$ outside end moraine constructed during a readvance.

General Comment (D.R.G.): shell material in till represents marine sediment plowed up by glacier readvancing, ca. 11,000 yr ago, down from Long Range plateau into a high postglacial sea over lowlands deglaciated $<1000$ yr earlier. Field relations indicate: 1) encroachment by sea to $>120 \mathrm{~m}$ and formation of De Geer moraines during initial retreat of ice; 2) readvance of ice to moraine in Ten Mile Lake; 3) fall of sea to ca. $60 \mathrm{~m}$ by time $(10,100 \pm 160$ B.P., GSC-1270) glacier had receded from moraine (Grant, 1969a; 1969b). (One 3-day count each).

\section{GSC-1266. Bonne Bay \\ $1730 \pm 140$ \\ A.D. 220 \\ $\delta C^{13}=-24.9 \%$}

Basal peat at 125 to $135 \mathrm{~cm}$ depth from deposit assoc. with pool complex ("flarks") in Long Range Mts., S of Bonne Bay, Newfoundland $\left(49^{\circ} 28^{\prime} 10^{\prime \prime} \mathrm{N}\right.$ Lat, $57^{\circ} 57^{\prime} 40^{\prime \prime} \mathrm{W}$ Long), at alt ca. $260 \mathrm{~m}$. Pool is one of several in depressions in serpentine bedrock, but higher water level is due to development of dam-like peat deposits from which sample was taken. Coll. 1968 with split-tube corer by R. D. Muir, Natl. Parks Branch (now with Canadian Wildlife Service, Ottawa). Comment (R.D.M.); date, although younger than expected, supports field evidence that peat deposit was developed in situ over $>1500$ yr period (Muir, 1970). $\mathrm{NaOH}$-leach omitted from sample pretreatment. (One 1-day count.)

\section{GSC-1145. Turf Point}

$7340 \pm 220$ 5390 в.C.

Plant detritus in basal sand of peat bog, Turf Point, St. George's 
Bay, Newfoundland ( $48^{\circ} 26^{\prime} \mathrm{N}$ Lat, $58^{\circ} 28^{\prime} \mathrm{W}$ Long). Sample from fresh exposure in wave-cut face of bog at sea level. Sand is eroded surface of massive compact till which also occurs in base of sections elsewhere around St. George's Bay (Brookes, 1969). NE of bog, till is overlain, successively, by marine silts and delta sands and gravels with a flat surface at alt ca. $24 \mathrm{~m}$. Coll. 1968 by I. A. Brookes, York Univ., Toronto, and V. K. Prest. Comment (I.A.B.): date is minimum for time when sea level was lower, relative to land, than at present. $\mathrm{NaOH}$-leach omitted from sample pretreatment. Sample mixed with dead gas for counting.

\section{GSC-1187. Port au Port}

$13,400 \pm 290$

Whole clean shells (Balanus sp.) $27 \mathrm{~m}$ below top of Bay St. George 'Delta' sequence at 'The Gravels', * Port au Port, Newfoundland $\left(48^{\circ}\right.$ $33.8^{\prime} \mathrm{N}$ Lat, $58^{\circ} 42.6^{\prime} \mathrm{W}$ Long), alt ca. $2 \mathrm{~m}$. Shells in situ on pebbles (up to $10 \mathrm{~cm}$ diam.) and infilled with bottomset silt and clay of 'Delta' sequence. Interstices of pebbles filled with sand. Coll. 1966 by J. M. Shearer, then at Memorial Univ., St. John's. Comment (J.M.S.): dates time of high-energy environment (waves or tidal currents) preceding deposition of bottomset silt assoc. with Bay St. George 'Delta' formation. Because date coincides with numerous others close to marine limit (all approximating time of deglaciation; cf. Brookes, 1969 and GSC-1200, $13,500 \pm 210$, this list), tidal currents were causal environment. Small sample size $(6.5 \mathrm{~g})$ precluded leaching of outer shell material. Sample mixed with dead gas for counting. (One 2-day count.)

\section{Robinsons Head series}

Marine shells and organic debris from 2 localities close together at $\mathrm{N}$ end Robinsons Head, E side of St. George's Bay, Newfoundland (48 $15^{\circ}$ N Lat, $58^{\circ} 47.5^{\prime} \mathrm{W}$ Long).

\section{GSC-1200. Robinsons Head, marine shells $\quad 13,500 \pm 210$}

Mollusk shell fragments, mainly Hiatella arctica and Mya sp., some with bits of periostracum attached, from $0.6 \mathrm{~m}$-layer of clayey silt in sea cliff at alt $36 \mathrm{~m}$. Clayey silt occurs ca. $14 \mathrm{~m}$ below cliff top and overlies coarse stratified ice-contact gravel and compact gray-pink till, both of St. George's River Drift (MacClintock and Twenhofel, 1940). Shelly layer is overlain by $2 \mathrm{~m}$ stratified sand, possibly deltaic in origin, above which less well-stratified, cobbly, kame gravels of Robinsons Head Drift, some $12 \mathrm{~m}$ thick, continue to cliff top. Clayey silt marks uppermost limit of identifiable marine deposits at Robinsons Head, but lateglacial sea probably extended up to $6 \mathrm{~m}$ higher. Coll. 1968 by I. A. Brookes. Comment (I.A.B.): dates maximum marine submergence following deglaciation of present shore area and prior to glacier readvance over a shoaling sea floor (Brookes, 1969; 1970b). Sample mixed with dead gas for counting.

* Single quotation marks used throughout text to indicate unofficial name. 
GSC-1350. Robinsons Head, organic debris

8650 B.c.

Organic debris transported fragments of tundra species of mosses (at least 16 species of mosses and vascular plants from both wet and dry habitats; Dryas integrifolia, Potamogeton sp., and dwarf Salix sp.; id. by M. Kuc) from basal $2.5 \mathrm{~cm}$ of $1.2 \mathrm{~m}$-thick peaty layer exposed in fresh-cut natural face on side of gully at alt ca. $28 \mathrm{~m}$. Peaty layer overlies marine clay, with an intervening irregular band of iron-stained gravel (correlative? with Robinsons Head Drift) up to $5 \mathrm{~cm}$ thick, and is overlain by $0.6 \mathrm{~m}$ gray marl and $2 \mathrm{~m}$ peat. Clay is probably same as outcropping nearby on Robinsons Head from which shells at alt $36 \mathrm{~m}$ were dated at 13,500 \pm 210 B.P. (GSC-1200; Brookes, 1969). Coll. 1969 by V. K. Prest. Comment (I.A.B.): organic debris postdates maximum marine transgression, ( 42.5 to $44 \mathrm{~m}$ at ca. 13,500 B.P.), and subsequent fall of sea level to $<27 \mathrm{~m}$. Local ice readvance that deposited Robinsons Head Drift occurred when sea level was at ca. 27 m. Hypothetical sealevel curve dates readvance at 13,000 B.P. (Brookes, 1970a); organic debris was transported to site ca. $2500 \mathrm{yr}$ later, when sea level was probably ca. 4.5 to $9 \mathrm{~m}$ lower, relative to land, than now. NaOH-leach omitted from sample pretreatment. (One 3-day count.)

\section{GSC-1203. Port au Port Bay}
$5800 \pm 210$ 3850 B.C.
$\delta C^{13}=+2.5 \%$ o

Shell fragments, including Cerastoderma pinnulatum (id. by A. H. Clarke, Jr., Natl. Mus. Nat. Sci., Ottawa), Hiatella arctica, Mya truncata and Balanus sp., from a gravelly-sand zone in predominantly clay and silt core from West Bay, Port au Port Bay, Newfoundland $\left(48^{\circ} 43^{\prime}\right.$ $\mathrm{N}$ Lat, $58^{\circ} 50.3^{\prime} \mathrm{W}$ Long), at ca. $24 \mathrm{~m}$ depth. Shell-bearing zone underlain by blue gray clay; overlain by brown silt similar to type of sediment now being deposited. Coll. 1966 by J. M. Shearer. Comment (J.M.S.): date thought minimum for time of greatest postglacial land emergence in area, assuming tidal currents are and were ineffective in basin and that sandy zone is due to wave action. Assuming similar wave energy and thus calculating depth at which orbital velocities are strong enough to transport sandy material, sea level 11 to $14 \mathrm{~m}$ lower relative to land is necessary. Small sample size (4.9 g) precluded leaching of outer shell material. Sample mixed with dead gas for counting.

\section{Abrahams Cove series}

Marine shells from near $\mathrm{E}$ end of Abrahams Cove, $\mathrm{S}$ side of Port au Port Peninsula, Newfoundland (48 $31.5^{\prime} \mathrm{N}$ Lat, $58^{\circ} 55^{\prime} \mathrm{W}$ Long).

\section{GSC-968. Abrahams Cove, $7.5 \mathrm{~m}$}

Whole shells and fragments (Hiatella arctica), some with ligament and periostracum intact, from sea cliff at $\mathrm{E}$ end of Abrahams Cove, at alt $7.5 \mathrm{~m}$. Shells occur in blue-black sandy, pebbly clay overlying a $0.6 \mathrm{~m}$ 
layer of buff sand, a massive compact gray-brown till, and bedrock, and overlain by deltaic gravel. Coll. 1966 by I. A. Brookes. (One 3-day count.)

GSC-1074. Abrahams Cove, 40 to $41 \mathrm{~m}$

$13,700 \pm 230$ Macoma (?) and Batamistica and fragments of Macoma (?) and Balanus sp.), some worn, from working face of borrow pit on rd. $0.4 \mathrm{~km} \mathrm{E}$ of bridge over stream at Abrahams Cove. Shells coll. at alt 40 to $41 \mathrm{~m}$ from bouldery limestone gravel; marine limit at $43 \mathrm{~m}$. Coll. 1968 by I. A. Brookes and J. M. Shearer.

General Comment (I.A.B.): dates maximum marine submergence, following deposition of underlying till and deglaciation of present shoreline, and suggests similar dates on shells in marine deposits close to sea level (e.g., GSC-1187, 13,400 \pm 290, this list; GSC-598, 13,420 \pm 190, R., 1968, v. 10, p. 210; GSC-937, $13,200 \pm 220$, R., 1970, v. 12, p. 51) relate closely to age of marine limit. GSC-1074 mixed with dead gas for counting.

\section{GSC-1135. North West River, Labrador \\ $5330 \pm 170$ \\ 3380 B.c. \\ $\delta C^{13}=+0.3 \%$}

Fragments of Mytilus edulis (NMC-311) 2 to $3.5 \mathrm{~m}$ below reworked surface of end moraine (Blake, 1956) on $\mathrm{S}$ side of stream at North West River, Labrador, Newfoundland (53 $31^{\prime} 20^{\prime \prime} \mathrm{N}$ Lat, $60^{\circ} 08^{\prime} 45^{\prime \prime} \mathrm{W}$ Long), alt ca. $33 \mathrm{~m}$ above high-water mark. Bed of comminuted shells, exposed in borrow pit NW of school, overlain by stratified sand and gravel and underlain by similar material. Coll. 1968 by W. W. Fitzhugh, Harvard Univ., Cambridge, Massachusetts; now at Smithsonian Inst., Washington, D.C. Comment (W.W.F. and W.B., Jr.): dates time during emergence when sea was truncating surface of moraine at North West River, and when Grand Lake to NW was marine. Sample mixed with dead gas for counting.

\section{Nova Scotia}

\section{Sable Island series (I)}

Numerous freshwater peat balls of varying size, presumably from submerged layers of peat on Sable Island Bank, litter beaches of Sable Island, Nova Scotia. Peat and soil layers developed on an enlarged land area at times of lower sea level during and since Wisconsin glaciation. As sea level rose in postglacial time peat was submerged and covered with marine sand. Subsequent shifting of sand exposed peat to erosion, chunks are washed onto island by storm waves. Distribution, composition, and ages of peat balls suggest that numerous disconnected lenses of peat of varying age probably exist beneath present island and surrounding banks (Terasmae and Mott, 1971). 
GSC-916. South Beach, peat ball

$\mathbf{5 8 2 0}$ в.c.

Rounded, wave-washed ball of peat recovered from high-water mark on beach at base of dunes along South Beach E of Lake Wallace $\left(43^{\circ}\right.$ $56^{\prime} \mathrm{N}$ Lat, 59 $52^{\prime}$ ' W Long). Coll. 1967 by J. Terasmae and R. J. Mott. Comment (R.J.M.): sample yielded pollen assemblage with relatively little tree pollen but with abundant pollen of Myrica and Ericaceae, indicating an environment similar to island's present-day heath areas which cannot support trees.

GSC-917. South Beach, peat ball

$6980 \pm 140$

5030 в.c.

Rounded, wave-washed ball of peat from South Beach W of Lake Wallace $\left(43^{\circ} 55.5^{\prime} \mathrm{N}\right.$ Lat, $60^{\circ} 02^{\prime} \mathrm{W}$ Long). Coll. 1966 by D. J. Stanley; subm. by R. J. Mott. Comment (R.J.M.): sample has pollen assemblage rich in tree pollen (Pinus sp.), suggesting presence of trees on island or long distance transport of large quantities of Pinus pollen. Because nontree part of pollen spectrum is similar to other spectra from samples of island area and because other evidence for presence of trees is lacking, latter explanation seems more likely. Date is similar to one of $6800 \pm$ 150 (GaK-748) on peat ball dredged from $9 \mathrm{~m}$ depth $1.6 \mathrm{~km} \mathrm{~S}$ of island (Clarke et al., 1967; James and Stanley, 1967).

\section{GSC-1009. West Point, peat slab (top)}

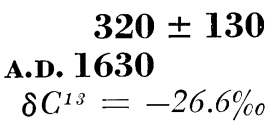

One of many large pieces of peat $(0.6 \mathrm{~m}$ diam., $25 \mathrm{~cm}$ thick $)$ washed onto beach at West Point $\left(43^{\circ} 56.5^{\prime} \mathrm{N}\right.$ Lat, $60^{\circ} 05^{\prime} \mathrm{W}$ Long) by storm waves. Sample from top $3.8 \mathrm{~cm}$ of peat slab. Coll. 1967 by J. Terasmae and R. J. Mott. Comment (R.J.M.): size and unrounded condition of peat slabs preclude long distance transport. Pollen spectrum contains abundant Cyperaceae, Myrica, and Ericaceae, indicating environment similar to that of some areas of island today. $\mathrm{NaOH}$-leach omitted from sample pretreatment. (One 3-day count.)

\section{GSC-1010. West Point, peat slab (base) \\ A.D. 1300

$$
\delta C^{13}=-24.6 \%
$$

$650 \pm 130$

Sample from basal $2.5 \mathrm{~cm}$ of same peat slab of GSC-1009. Comment (R.J.M.): pollen spectrum has relatively little Cyperaceae but abundant Myrica, Ericaceae, and Gramineae pollen; environment same as GSC1009. NaOH-leach omitted from sample pretreatment. Sample mixed with dead gas for counting. (One 3-day count.)

\section{GSC-935. Mobil Oil drill hole, peat}

$10,900 \pm 160$

Small piece of sandy peat recovered from top $18 \mathrm{~m}$ of sand during washing down of casing for Mobil Oil test hole on Sable I. $\left(43^{\circ} 56^{\prime}\right.$

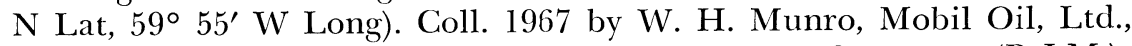
Calgary; subm. by J. Terasmae and R. J. Mott. Comment (R.J.M.): 
pollen spectrum contains very little tree pollen but abundant Cyperaceae, Gramineae and Myrica pollen. Even 11,000 yr ago trees do not appear to have been present on island and environments similar to some on present island were prevalent. $\mathrm{NaOH}$-leach omitted from sample pretreatment.

Sable Island series (II)

Marine shells from North Beach near West Light, Sable I., Nova Scotia $\left(43^{\circ} 55^{\prime} \mathrm{N}\right.$ Lat, $60^{\circ} 10^{\prime} \mathrm{W}$ Long). Coll. 1966 by A. H. Clarke, Jr., Natl. Mus. Nat. Sci., Ottawa.

GSC-634. West Light, oyster

beassostrea virginica (Gmelin), from (10\% of shell and after different-colored layers of shell were separated:

white layers of shell; mixed with dead gas for counting $3540 \pm 140$

black layers of shell; one 3-day count

$3630 \pm 130$

GSC-635. West Light, oyster (unblackened)

$5650 \pm 140$

Unblackened oysters

Two determinations, after removal of outer $10 \%$ of shell:

outer fraction (21-55\% leach), one 4-day count

inner fraction $(56-100 \%$ leach), one 3-day count

3700 B.C.

GSC-699. West Light, bay scallop

$5320 \pm 140$

$5650 \pm 140$

A.D. 150

Unblackened bay scallops (Aequipecten irradians sablensis Clarke) from beach. (One 3-day count.)

General Comment (A.H.C., Jr.): neither oysters nor bay scallops now live near Sable I.; nor do latter live in E Canada. However, shells are often found on beaches and surrounding Sable I. Bank. GSC-634 and 635 indicate that oysters lived at Sable I. during Hypsithermal. Presence of both taxa suggests lagoon or bay during approx. interval 5650 to $3550 \mathrm{yr}$ B.P. and again from ca. 1800 to 1400 yr B.P. (cf. GX-73, $1430 \pm$ 125, also on bay scallop; Clarke, 1965; R., 1966, v. 8, p. 146; Clarke et al., 1967).

\section{GSC-1395. Ingonish}

$$
\begin{array}{r}
40 \\
\text { A.D. } 1910
\end{array}
$$

Metapodial bone from Wooland Caribou (Rangifer tarandus bou, id. by P. M. Youngman Caribou (Rangifer tarandus caribou, id. by P. M. Youngman, Natl. Mus. Nat. Sci., Ottawa) excavated from $0.5 \mathrm{~m}$ thick forest peat filling kettles in hummocky ice contact gravel deposit $0.8 \mathrm{~km} \mathrm{~W}$ of Keltic Lodge, $1.6 \mathrm{~km} \mathrm{SE}$ of Ingonish Center, Cape Breton Highlands Natl. Park, Nova Scotia $\left(46^{\circ} 39.2^{\prime} \mathrm{N}\right.$ Lat, $60^{\circ}$ $23.7^{\prime} \mathrm{W}$ Long), at alt ca. $23 \mathrm{~m}$. Coll. 1969 by F. Seymour, Ingonish; subm. by P. M. Youngman. Comment (D.R. Grant): bone originally 
reported at $5 \mathrm{~m}$ depth; since species only became extinct in this century (P. M. Youngman, pers. commun.) a much greater age was possible. Date not surprising in view of shallow burial. Pretreatment of small sample $(177 \mathrm{~g})$ included 1-hr NaOH-leach. Sample mixed with dead gas for counting. (One 3-day count.)

\section{Recent submergence series, Maritime Provinces (II)}

Sedge peat from intertidal cliff sec. exposing 0 to $9 \mathrm{~m}$ salt marsh peat overlying thin layer of sedge peat and humus, with small bushes rooted in till, $\mathrm{N}$ bank of Maccan R. $1.6 \mathrm{~km} \mathrm{~S}$ of Amherst Point, Nova Scotia $\left(45^{\circ} 46.55^{\prime} \mathrm{N}\right.$ Lat, $64^{\circ} 16.95^{\prime} \mathrm{W}$ Long). These 4 samples of material known to have formed and been deposited at highest tide level, were chosen to obtain a more precise measure of recent changes of high-tide level in upper Bay of Fundy than was hitherto inferred from single determinations at numerous scattered localities. All depths below local level of Mean Higher High Water at large tides.

\section{GSC-1076. Amherst Point, 3.8 m depth}

\section{GSC-1079. Amherst Point, $4.6 \mathrm{~m}$ depth}

\section{GSC-1073. Amherst Point, $6.9 \mathrm{~m}$ depth}

\section{GSC-1075. Amherst Point, 8.1 m depth}

$$
1800 \pm 130
$$$$
\text { A.D. } 150
$$$$
\delta C^{13}=-24.5 \%
$$$$
1910 \pm 130
$$$$
\text { A.D. } 40
$$$$
\delta C^{13}=-24.4 \%
$$$$
2750 \pm 150
$$$$
800 \text { B.C. }
$$$$
\delta C^{13}=-23.3 \%
$$

$2960 \pm 130$

1010 B.C.

$\delta C^{13}=-24.4 \%$ o

General Comment (D.R.G.): high tide level was elev. by $4.3 \mathrm{~m}$ over an 1100 to 1200 -yr period, confirming earlier indications that high tide has been rising throughout most of Bay of Fundy at average rate of ca. $30 \mathrm{~cm} /$ century during last $4000 \mathrm{yr}$ (Grant, 1970). (Note: data for GSC$992,1260 \pm 140$, R., 1970 , v. 12 , p. 53 , should have read "salt marsh peat at $-9.8 \mathrm{ft}$ overlying $8 \mathrm{in} . .$. .", not $26 \mathrm{ft}[8 \mathrm{~m}])$. NaOH-leach omitted from pretreatment of samples. GSC-1073 mixed with dead gas for counting; one 1-day count. GSC-1076 and GSC-1079 each based on one 3-day count; GSC-1075, one 5-day count.

\section{GSC-1288. Nictaux Falls}

$60 \pm 130$

Marine shells (2 valves of Mya arenaria) in gravel of railway borrow pit, E bank of Nictaux R. ca. $0.5 \mathrm{~km} \mathrm{NE}$ of Nictaux Falls, Nova Scotia $\left(45^{\circ} 54.75^{\prime} \mathrm{N}\right.$ Lat, $65^{\circ} 01.52^{\prime} \mathrm{W}$ Long). Coll. 1923 by E. R. Faribault; subm. by D. R. Grant. Comment (D.R.G.): site is at alt $38 \mathrm{~m}$, and geologic evidence suggests marine limit is $<30 \mathrm{~m}$; shells were dated in hope they would relate to retreat of late ice cap in S Nova Scotia (Prest 
and Grant, 1969) and fall of high postglacial sea. Date suggests shells represent remains of a clam bake. Sample mixed with dead gas for counting. (One 3-day count.)

\section{Prince Edward Island}

\section{GSC.1421. Basin Head}

$130 \pm 130$

Compressed humus layer (woody detritus, bark, twigs, fungi; M. Kuc, written commun.) in dune sand, $2.7 \mathrm{~m}$ below surface, exposed along tidal channel through barrier beach/dune complex just $\mathbf{E}$ of Basin Head, Prince Edward I. (46 $22.8^{\prime} \mathrm{N}$ Lat, $62^{\circ} 06.5^{\prime} \mathrm{W}$ Long), at ca. $2 \mathrm{~m}$ above high tide level. Coll. 1967 by D. R. Grant. Comment (D.R.G.): humus, the lower of 2 organic horizons, is interpreted as buried soil, representing interruption of sand movement; similar to GSC-461 (210 \pm 130; R., 1968, v. 10, p. 210) from Sable I., Nova Scotia. $\mathrm{NaOH}$-leach omitted from sample pretreatment. (One 1-day count.)

\section{New Brunswick}

\section{GSC-1340. Saint John}

$13,000 \pm 170$

Marine shells (mainly Mya sp., with Balanus sp., Serripes groenlandicus, Macoma calcarea) from ca. $9 \mathrm{~m}$ above high tide level in cliff face ca. $0.8 \mathrm{~km} \mathrm{~W}$ of Sheldon Point, W of Saint John, New Brunswick $\left(45^{\circ} 13^{\prime} 30^{\prime \prime} \mathrm{N}\right.$ Lat, $66^{\circ} 06^{\prime} 20^{\prime \prime} \mathrm{W}$ Long), i.e., same locality as I(GSC)-7 $(13,325 \pm 500$; R., 1961 , v. 3, p. 50) and GSC-965 (13,200 \pm 200; R., 1970 , v. 12, p. 55). Red clay forming cliffs interdigitates with gravel. Coll. 1969 by N. R. Gadd. Comment (N.R.G.): deposit previously described as deltaic (glaciomarine?) is believed possibly a bar or spit developed on submerged moraine. Sample from higher level in marine sediment than those subm. by Lee and Welsted to show, if possible, time range of marine submergence. 'Though perhaps younger, date GSC-1340 overlaps previous determinations. (One 3-day count.)

\section{Quebec}

\section{GSC-1018. New Richmond}

$12,200 \pm 180$ 10,250 в.c.

Marine shells (mainly Mya truncata and Hiatella arctica) exposed in cliff, $\mathrm{N}$ shore Chaleur Bay near New Richmond, Quebec $\left(48^{\circ} 10^{\prime}\right.$ $\mathrm{N}$ Lat, $65^{\circ} 52^{\prime} \mathrm{W}$ Long), alt $0.6 \mathrm{~m}$ in $3 \mathrm{~m}$ thick gray-blue clay overlain by deltaic sand. Coll. 1967 by R. Héroux, Ministère des Terres et Forêts, Quebec. Comment (D.R. Grant): shells occur ca. $37 \mathrm{~m}$ below marine limit, but date approximates age of highest marine features (i.e., deglaciation) because early postglacial fall of relative sea level is typically several $\mathrm{m} /$ per century. Also dates withdrawal of a late glacial lobe from Chaleur Bay (Prest and Grant, 1969). (One 4-day count in 2-L counter at $1 \mathrm{~atm}$.) 


\section{GSC-1186. Ruisseau-à-Rebours, Gaspé N. Co.}

$$
12,600 \pm 160
$$

Shells (Mya truncata) from ca. $1 \mathrm{~m}$ depth in sandy clay forming terraces in valley of Ruisseau-à-Rebours, Gaspé N. Co., Quebec $\left(49^{\circ}\right.$ $13^{\prime} 20^{\prime \prime} \mathrm{N}$ Lat, $65^{\circ} 56^{\prime} \mathrm{W}$ Long), alt ca. $45 \mathrm{~m}$. From rd. cut $0.4 \mathrm{~km}$ from Hwy 6. Pelecypods with joined valves in situ included Mya truncata, Hiatella arctica, and Macoma calcarea. Coll. 1965 by J. C. Dionne, Forest Research Lab., Dept. Forestry and Rural Development, Quebec. Comment (J.C.D.): maximum postglacial submergence of $\mathrm{N}$ coast Gaspé Peninsula near Mont-St-Pierre did not exceed $60 \mathrm{~m}$. Date thought to refer to early submergence; it agrees with GSC-89; 12,940 \pm 180 , on Anticosti I. and GSC-102; 12,720 \pm 170 , at Trois-Pistoles (both in R., 1963, v. 5, p. 42.) (One 3-day count.)

\section{GSC-1337. Moisie River}

$9140 \pm 200$ 7190 в.c.

Whole shells and fragments of Macoma calcarea, id. by V. Condé, McGill Univ., from upper part of silty clay near QNS\&L Railway tunnel $17.5 \mathrm{~km} \mathrm{E}$ of Sept-Îles and $19.5 \mathrm{~km} \mathrm{~N}$ of mouth of Moisie R., Quebec $\left(50^{\circ} 18^{\prime} \mathrm{N}\right.$ Lat, $66^{\circ} 12^{\prime} \mathrm{W}$ Long), alt $76 \mathrm{~m}$. Clay overlain by ca. $30 \mathrm{~m}$ sand deposited during marine regression. Coll. 1969 by L. Dredge, McGill Univ., Montreal. Comments (L.D.): date should approximate time of maximum marine submergence (alt $128 \mathrm{~m}$ ) for Sept-Îles area; (W.B., Jr.): date is similar to I-3868, $9150 \pm 150$, (Sauvé and LaSalle, 1968) on Balanus sp., alt $64 \mathrm{~m}$ at Manic 2, Manicouagan R., $193 \mathrm{~km} \mathrm{SE}$. Sample small $(7.2 \mathrm{~g})$, so only outer $5 \%$ of shell removed by leaching. Sample mixed with dead gas for counting. (One 3-day count).

\section{GSC-1104. Saint-Donat, Rimouski Co.}

$12,000 \pm 160$

Shells (Hiatella arctica) in situ with joined valves, from $0.6 \mathrm{~m}$ depth in silty clay on bedrock, $0.6 \mathrm{~km} \mathrm{NW}$ of Saint-Donat, Rimouski Co., Quebec (48 $30^{\prime} 30^{\prime \prime} \mathrm{N}$ Lat, $68^{\circ} 16^{\prime} 10^{\prime \prime} \mathrm{W}$ Long), alt ca. $100 \mathrm{~m}$, close to marine limit. Coll. 1965 by J. C. Dionne. Comment (J.C.D.): date is minimum for deglaciation and postglacial submergence of Mitis and Neigette Valleys. As it is younger than GSC-89, 12,940 \pm 180 , Anticosti I. and GSC-102, 12,720 \pm 170 , Trois-Pistoles (both in R., 1963, v. 5, p. 42) and GSC-1186, 12,600 \pm 160 (this list), dead ice may have delayed marine invasion. (One 3-day count.)

\section{GSC-1216. Bic, Rimouski Co.}

$9450 \pm 150$ 7500 B.c.

$$
\delta C^{13}=+3.0 \% \text { o }
$$

Shells (Mya pseudoarenaria) from silty sand underlain by marine clay and overlain by beach sand and gravel at $1.5 \mathrm{~m}$ depth in rd. cut in terrace, near bridge crossing Bic R. on Hwy $6\left(48^{\circ} 22^{\prime} 35^{\prime \prime} \mathrm{N}\right.$ Lat, $68^{\circ} 42^{\prime} 25^{\prime \prime} \mathrm{W}$ Long), alt ca. $14 \mathrm{~m}$. Shells with joined valves in situ from richly fossiliferous site. Coll. 1964 by J. C. Dionne. Comment (J.C.D.): maximum postglacial submergence of area did not exceed $100 \mathrm{~m}$. If 
pelecypods were living on tidal flat, date indicates age of $15 \pm 5 \mathrm{~m}$ level. GX-1492, $9864 \pm 180$, at same alt at St. Patrick (Rivière-du-Loup Co.), $113 \mathrm{~km} \mathrm{SW}$ of Bic, is similar.

GSC-1137. St. Martin

Finely divided plant fragments in lake sediment sheared into till. Coll. 1968 by W. W. Shilts from excavation for foundation of St. Martin École Polyvalente, St. Martin, Quebec $\left(45^{\circ} 57.6^{\prime} \mathrm{N}\right.$ Lat, $70^{\circ} 39.1^{\prime} \mathrm{W}$ Long), at alt ca. $275 \mathrm{~m}$. Sample from $3 \mathrm{~m}$ below original surface. Comments (W.W.S.): roots present to base of excavation; $46 \mathrm{~g}$ organic material concentrated from ca. $200 \mathrm{~kg}$ sediment. Sediment included in surface till and thought to correlate with widespread lake sediments underlying surface till in Chaudière River valley (Shilts, 1969; McDonald and Shilts, 1971); (W.B., Jr.): some bits of rootlets (?) or fibers (?) noticed in sample; all visible pieces removed by B. C. McDonald. NaOHleach omitted from sample pretreatment. Sample mixed (high ratio) with dead gas for counting as $40 \mathrm{~g}$ of sample burned after acid treatment yielded only $1.6 \mathrm{~cm} \mathrm{CO}_{2}$. (One 3-day count.)

GSC-1084. Rivière Grande Coulée

$>40,000$

Finely disseminated plant detritus and wood fragments up to $1 \mathrm{~cm}$ long, from $13 \mathrm{~m}$ depth in 1 of several secs. on Rivière Grande Coulée, $5.1 \mathrm{~km} \mathrm{SW}$ of St. Martin, Quebec ( $45^{\circ} 55.8^{\prime} \mathrm{N}$ Lat, $70^{\circ} 42.2^{\prime} \mathrm{W}$ Long), at alt ca. $300 \mathrm{~m}$. Enclosing sediment is medium- to coarse-grained, noncalcareous, orange-red, structureless sand; it underlies surface till and lake sediment and overlies till and fluvial gravel. Coll. 1967 and 1968 by W. W. Shilts; subm. by B. C. McDonald. Comment (W.W.S.): sediment thought to correlate with St. Pierre sediments on basis of pollen representing climate cooler than present (R. J. Mott, pers. commun.) and stratigraphic position (Shilts, 1969; McDonald and Shilts, 1971). NaOHleach omitted from sample pretreatment. (One 3-day count.)

\section{GSC-1176. Eaton River}

$260 \pm 130$

\section{A.D. 1690}

$\delta C^{13}=-22.0 \%$

Wood from borehole on right bank of Eaton R. ca. $400 \mathrm{~m}$ downstream from confluence with Clifton R., Quebec $\left(45^{\circ} 20^{\prime} \mathrm{N}\right.$ Lat, $71^{\circ} 33^{\prime}$ W Long), alt ca. $260 \mathrm{~m}$ at collar of hole. Coll. 1968 by G. Simard, Ministère des Richesses Nat., Quebec; subm. by B. C. McDonald. Comment (B.C.M.): wood thought to derive from till unit at $10 \mathrm{~m}$ depth in hole; young age suggests it came from modern alluvium overlying till. (One 3-day count.)

\section{GSC-1213. Normandin Dunes}

Sandy peat at $3.9 \mathrm{~m}$ depth from boring with Hiller peat sampler in interbedded eolian sand and peat in kettle on delta of former Laflamme Sea, $11.5 \mathrm{~km} \mathrm{~W}$ of Normandin, lac St-Jean area, Quebec $\left(48^{\circ}\right.$ 
$51^{\prime} \mathrm{N}$ Lat, $72^{\circ} 41^{\prime} \mathrm{W}$ Long), alt ca. $190 \mathrm{~m}$. Sample from top of basal peat layer. Coll. 1968 by J. Lebuis; subm. by P. P. David, Univ. of Montreal, Montreal. Comment (J.L. and P.P.D.): date is minimum for formation of delta in Laflamme Sea at $190 \mathrm{~m}$ alt. Date is similar to I-3144, $7750 \pm 135$ (Lasalle, 1968; 1969), from basal peat at same alt elsewhere in area, but marine invasion occurred $>9000$ yr ago (Lasalle and Rondot, 1967). Also dates earliest period of dune formation in region (Lebuis, 1971). NaOH-leach omitted from sample pretreatment. (One 3-day count.)

\section{Val St. Gilles series}

Wood and peat exposed on flank of esker along $W$ shore of Lac Bissonnette, $4.0 \mathrm{~km} \mathrm{NNE}$ of Val St. Gilles and ca. $80 \mathrm{~km} \mathrm{~N}$ of Noranda, Quebec ( $49^{\circ} 01^{\prime} \mathrm{N} \mathrm{Lat}, 79^{\circ} 05^{\prime} \mathrm{W}$ Long), at alt ca. $290 \mathrm{~m}$.

\section{GSC-585. Val St. Gilles, wood}

$5030 \pm 130$

White pine wood (Pinus strobus L., id. by R. J. Mott) from log ca. $90 \mathrm{~cm}$ diam., under ca. $1.5 \mathrm{~m}$ peat. Coll. 1965 by F. Miron, Amos, Quebec; subm. by J. Terasmae, now at Brock Univ., St. Catharines, Ontario. Comment (J.T.): sample ca. $96 \mathrm{~km} \mathrm{~N}$ of present limit of white pine, indicating mid-Holocene northward extension of range of this species (Terasmae and Anderson, 1970). (One 3-day count.)

\section{GSC-788. Val St. Gilles, peat}

$6460 \pm 140$

Peat from base of $3 \mathrm{~m}$ thick sec. overlying stratified sand and gravel. Coll. 1966 by J. Terasmae. Comment (J.T.): date is minimum for drainage of Glacial Lake Barlow-Ojibway in area. $\mathrm{NaOH}-$ leach omitted from sample pretreatment. (One 3-day count.)

\section{Ontario}

\section{McKay Lake series, Rockliffe}

McKay Lake, at alt $44 \mathrm{~m}$, is a small lake in re-entrant in limestone escarpment on S side of Ottawa R. in Village of Rockcliffe, Ontario $\left(45^{\circ} 27^{\prime} \mathrm{N}\right.$ Lat, $75^{\circ} 40^{\prime} 15^{\prime \prime} \mathrm{W}$ Long). Clay deposited by Champlain Sea partly filled basin; lake formed following emergence of area from Champlain Sea and shifting of channels of ancestral Ottawa and/or Rideau Rivers. Coll. 1966 by R. H. McNeely, Queens Univ., Kingston (now at Brock Univ., St. Catharines, Ontario) and R. J. Mott.

\section{GSC-621. McKay Lake, basal organic sediment 6060 B.C.}

Laminated, algal gyttja from 458 to $468 \mathrm{~cm}$ below mud/water interface in ca. $10.6 \mathrm{~m}$ water. Comment (R.J.M.): dates start of organic deposition in lake basin and is minimum for abandonment of depression as river channel; cf. GSC-546 (8830 \pm 190$)$, GSC-547 (8220 \pm 150$)$, and GSC-628 (7870 \pm 160$)$, all related to former channels of Ottawa R. (R., 
1967, v. 9, p. 161-162). NaOH-leach omitted from sample pretreatment. Sample mixed with dead gas for counting. (One 3-day count.)

\section{GSC-622. McKay Lake, surface ooze}

$1310 \pm 160$

Cia. $30 \mathrm{~cm}$ of dark gray to black ooze overlies normal gray to brown algal gyttja; sample from 25 to $29.5 \mathrm{~cm}$ depth below mud/water interface. Comment (R.J.M.): surficial dark ooze layer indicates major change in lake environment. $\mathrm{NaOH}-\mathrm{leach}$ omitted from sample pretreatment. Sample mixed with dead gas for counting.

\section{Roblin Lake series}

Samples from Roblin Lake, $0.8 \mathrm{~km} \mathrm{~S}$ of Ameliasburg, Prince Edward Co., Ontario (44 $03^{\prime} \mathrm{N}$ Lat, $77^{\circ} 25^{\prime} \mathrm{W}$ Long); alt of lake $109 \mathrm{~m}$; water depth, $13.5 \mathrm{~m}$. Samples coll. winter 1963 by J. Terasmae with Shelbytube sampler, diam. $5 \mathrm{~cm}$. Palynologic studies were made of core samples (Terasmae and Mirynech, 1964); cf. GSC-156 (7620 \pm 170 ; R., 1964, v. 6 , p. 169), was on gyttja from $860 \mathrm{~cm}$ below water-sediment interface; it coincided with lower part of a pollen zone in which percentages of hemlock (Tsuga), beech (Fagus) and elm (Ulmus) pollen increased significantly.

\section{GSC-379. Roblin Lake, $220 \mathrm{~cm}$}

$2120 \pm 140$

Gyttja from $220 \mathrm{~cm}$ depth below water-sediment interface. Comment (J.T.): dates beginning of late-Holocene rise of spruce pollen percentages in pollen diagram.

\section{GSC-380. Roblin Lake, $480 \mathrm{~cm}$}

$3330 \pm 130$

Gyttja from $480 \mathrm{~cm}$ depth below water-sediment interface. Comment (J.T.): postdates upper boundary of mid-Holocene pollen zone characterized by abundant pine pollen.

\section{GSC-925. Roblin Lake, 1024 to $1035 \mathrm{~cm}$}

$10,500 \pm 150$ in sediment interface. Comment (J.T.): dates upper part of zone in which spruce pollen is predominant.

Plant detritus in silt and fine sand at 1070 to $1082 \mathrm{~cm}$ depth below water-sediment interface. Comment (J.T.): dates boundary between zone in which spruce pollen is abundant and next older zone characterized by relative abundance of non-tree pollen. Date is also minimum for establishment of Roblin Lake after drainage of Glacial Lake Iroquois and beginning of deposition of organic sediments in this lake basin (Terasmae and Mirynech, 1964).

General Comment (W.B., Jr.): NaOH-leach omitted from pretreatment 
of all samples. Dates for GSC-380 and GSC-890 based on one 5-day count and one 4-day count, respectively.

GSC-816. Niagara Falls

$22,800 \pm 450$

20,850 B.C.

Wood fragments and twigs from $46 \mathrm{~m}$ depth in borehole in buried St. Davids gorge, ca. $90 \mathrm{~m} \mathrm{E}$ of intersection of Whirlpool Rd., and Churches Lane, Niagara Falls, Ontario $\left(43^{\circ} 07^{\prime} 40^{\prime \prime} \mathrm{N}\right.$ Lat, $79^{\circ} 05^{\prime} \mathrm{W}$ Long). Approx. alt of drilling site, $180 \mathrm{~m}$. Coll. 1966 by J. Terasmae. Comment (J.T.): sample is from approx. middle of $21 \mathrm{~m}$ thick unit of stratified sand, silt, and clay. Pollen assemblages recovered from these sediments are characterized by spruce (Picea) pine (Pinus) and birch (Betula); with Artemisia, Ambrosia, Compositae, Gramineae, and Cyperaceae present in non-tree component. Cool (boreal) climate is inferred from palynologic evidence, and non-glacial interval is correlated with Plum Point interstadial of Lake Erie region (Hobson and Terasmae, 1969). Non-glacial sediments both underlain and overlain by ca. $30 \mathrm{~m}$ glacial deposits in buried gorge of ancient Niagara R. (One 3-day count.)

\section{Cudia Park series, Scarborough}

Organic detritus from lens in sand of Thorncliffe Formation, exposed in Scarborough Bluffs at Cudia Park, Ontario $\left(43^{\circ} 43^{\prime} 15^{\prime \prime} \mathrm{N}\right.$ Lat, $79^{\circ} 13^{\prime} 30^{\prime \prime} \mathrm{W}$ Long). Previous sample from same lens of organics, ca. $0.5 \mathrm{~m}$ above top of Early Wisconsin Sunnybrook Till, was 38,900 \pm 1300 yr old (GSC-271; R., 1966, v. 8, p. 104).

\section{GSC-534. Cudia Park, Scarborough (II)}

$$
48,800 \pm 1400
$$

Coll. 1965 by P. F. Karrow, Univ. of Waterloo, Waterloo, to check reproducibility of GSC-271, coll. 1964. Comment (P.F.K.): of 3 dates from same lens of organics, oldest date (GSC-1228, >53,000, this list) is presumed most nearly correct. Conflicting series suggests decreasing contamination farther in from face; GSC-1228 coll. 3 yr after GSC-534. Date as old as GSC-1228 is either due to contamination by reworking of older organic matter (abundant in Scarborough Formation lower in sec.) or to earlier retreat of Early Wisconsinan ice than presently assumed. Organics are stratigraphically of Port Talbot age. (Three 1-day counts in 5 - $\mathrm{L}$ counter at $4 \mathrm{~atm}$.)

\section{GSC-1228. Cudia Park, Scarborough (III)}

Coll. 1968 by A. A. Berti, Univ. of Western Ontario, London, to try to resolve difference between GSC-271 and -534. Comment (A.A.B.): macrofossil analysis yielded leaves of Dryas integrifolia, a tundra species, and of Picea and Larix; seeds of Carex aquatilis, Viola, Potamogeton, Potentilla, and Polygonum were also present, id. by A. A. Berti and by J. H. McAndrews, Royal Ontario Mus., Toronto. Average pollen count of 2 samples yielded (based on sum of trees and shrubs): Picea 29\%, Pinus $60 \%$, Abies $1 \%$, Betula $1 \%$, Quercus $2 \%$, Ulmus $0.8 \%$, and herbs $8.3 \%$ (mainly Cyperaceae and Gramineae). Macrofossils, particularly 
leaves, are probably primary and indicate that both forested and barren areas were present. Karrow and Terasmae's contention (Karrow, 1969) that organics are not reworked is supported, since fragile Dryas leaves have not been broken beyond recognition; thus, finite dates GSC-271 and GSC-534 probably were obtained on samples containing younger, secondary organic material. Age and stratigraphic position of GSC-1228 indicate this part of Thorncliffe Formation is older than Port Talbot II beds of Lake Erie basin (Dreimanis et al., 1966; Dreimanis, 1969) and is younger than Early Wisconsin Bradtville Till of Lake Erie basin with which Sunnybrook Till is correlated. Pretreatment included cold $\mathrm{NaOH}-$ leach. (One 2-day and one 3-day count in 5-L counter at 4 atm.)

\section{Scarborough Bluff series}

Organic detritus exposed in unoxidized lacustrine silt and clayey silt in upper part of Thorncliffe Formation, Scarborough Bluffs, Toronto. Coll. 1968 (GSC-1082) and 1969 (GSC-1221) by A. A. Berti.

\section{GSC-1082. Hi section}

$28,300 \pm 600$

Fine organic detritus from $1.3 \mathrm{~cm}$ thick, contorted, organic horizon exposed in Hi sec. (Karrow, 1967) (43. $41^{\prime} 7^{\prime \prime} \mathrm{N}$ Lat, $79^{\circ} 13^{\prime} 38^{\prime \prime} \mathrm{W}$ Long), from $2.5 \mathrm{~m}$ above top of Meadowcliffe Till and ca. $10.5 \mathrm{~m}$ below base of Leaside Till. Pollen analysis yielded (based on sum of trees and shrubs): Picea $30 \%$, Pinus $64 \%$, Larix $1.7 \%$, Betula $0.9 \%$, and herbs $12.8 \%$ (mainly Cyperaceae and Gramineae). Macrofossil analysis yielded leaves of Dryas integrifolia (id. by J. H. McAndrews), a tundra species.

\section{GSC-1221. Sunnypoint section}

$32,000 \pm 690$

Fine plant detritus from horizontally bedded lens of organic sediments ca. $8 \mathrm{~cm}$ thick and $1+\mathrm{m}$ in lateral extent, exposed in NW wall

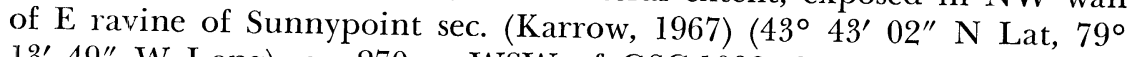
$13^{\prime} 49^{\prime \prime}$ W Long), ca. $270 \mathrm{~m}$ WSW of GSC-1082. Sample from ca. $2 \mathrm{~m}$ above top of Meadowcliffe Till. Pollen analysis yielded (based on sum of trees and shrubs): Picea $34 \%$, Pinus $56 \%$, Larix $1 \%$, Betula $3 \%$, Quercus $4 \%$, and herbs $14 \%$ (mainly Cyperaceae). Macrofossil analysis yielded leaves of Salix herbacea, an arctic-alpine species, of Vaccinium vitis-idaea, a subarctic-boreal species, of Dryas integrifolia, a tundra species, and seeds of a wide-ranging sedge, Carex aquatilis.

General Comment (A.A.B.): dates record non-glacial interval in Lake Ontario basin ca. 30,000 yr B.P. Macrofossil data suggest treeless conditions, at least in part, for Toronto area at that time. Pollen studies are in progress to decide if dates are contemporaneous or if ice-free interval of ca. 4000 yr duration occurred. Dates support Karrow's (1967) assignment of Leaside Till to Late Wisconsin, but Meadowcliffe Till apparently is Mid-Wisconsin. Dates are slightly older than, but probably belong to, Plum Point Interstade (Dreimanis et al., 1966) of Lake Erie 
basin. $\mathrm{NaOH}$-leach omitted from pretreatment of both samples. GSC1082 mixed with dead gas for counting. Dates for GSC-1082 and GSC1221 based on one 3-day count and one 2-day count, respectively.

\section{North Bay series}

Dates based on gyttja from basal organic sediments of small lake basins near North Bay, Ontario, in lowland forming present divide between Lake Nipissing and headwaters of Mattawa R. Samples provide chronologic data on stabilization and subsequent cessation of Upper Great Lakes drainage via North Bay outlet into Ottawa Valley system. Coll. 1966 by C. F. M. Lewis and J. Terasmae with a Livingstone piston corer from deepest water area in each lake. Most dated samples are composites taken from equivalent stratigraphic levels in 2 or more replicate cores. Elevations of lake surfaces were determined by spirit leveling and are given relative to Canadian Geodetic Datum.

\section{GSC-815. Dreany Lake}

$8200 \pm 160$

Gyttja from lowermost $6 \mathrm{~cm}$ of $6.8 \mathrm{~m}$-thick organic sediment sequence in Dreany Lake, alt $213.5 \mathrm{~m}$, water depth $3.3 \mathrm{~m}\left(46^{\circ} 17^{\prime} 26^{\prime \prime}\right.$ $\mathrm{N}$ Lat, $79^{\circ} 21^{\prime} 45^{\prime \prime} \mathrm{W}$ Long), ca. $4.5 \mathrm{~km} \mathrm{E}$ of junction of Hwys. 11 and 17. Sample overlay, in turn, $1 \mathrm{~cm}$ silty clay, $3 \mathrm{~cm}$ medium-grained sand, and stratified fine-grained sand.

\section{GSC-821. Lake ' $\mathbf{N}$ '}

$8320 \pm 170$

Gyttja from lowermost $5 \mathrm{~cm}$ of $4.0 \mathrm{~m}$-thick organic sediment sequence in Lake ' $\mathrm{N}$ ', alt $211.8 \mathrm{~m}$, water depth $0.6 \mathrm{~m}\left(46^{\circ} 17^{\prime} 23^{\prime \prime} \mathrm{N}\right.$ Lat, $79^{\circ} 20^{\prime} 06^{\prime \prime} \mathrm{W}$ Long), $2.4 \mathrm{~km} \mathrm{E}$ of junction of Hwys. 11 and 17. Sample overlay, successively, $20 \mathrm{~cm}$ silty sand with scattered plant fibers, $8 \mathrm{~cm}$ laminated silt and clay, $9 \mathrm{~cm}$ sorted fine- and mediumgrained sand, $76 \mathrm{~cm}$ laminated silt and clay, and varved silty clay.

\section{GSC-828. Lake ' $G$ '}

$4580 \pm 160$

Gyttja from lowermost $6 \mathrm{~cm}$ of $2.1 \mathrm{~m}$-thick organic sediment sequence in Lake ' $G$ ', alt $206.8 \mathrm{~m}$, water depth $5.4 \mathrm{~m}\left(46^{\circ} 18^{\prime} 21^{\prime \prime} \mathrm{N}\right.$ Lat, $79^{\circ} 24^{\prime} 10^{\prime \prime} \mathrm{W}$ Long), $2.4 \mathrm{~km} \mathrm{E}$ of junction of Hwys. 11 and 17. Sample overlay $18 \mathrm{~cm}$ silt with minor gyttja and $10 \mathrm{~cm}$ sorted mediumgrained sand, over stratified silty sand.

\section{GSC-808. Delaney Lake}

$4430 \pm 160$

Gyttja from lowermost $6 \mathrm{~cm}$ of $1.5 \mathrm{~m}$-thick organic sediment sequence in Delaney Lake, alt $204.6 \mathrm{~m}$, water depth $4.8 \mathrm{~m}\left(46^{\circ} 18^{\prime} 58^{\prime \prime}\right.$ $\mathrm{N}$ Lat, $79^{\circ} 25^{\prime} 51^{\prime \prime} \mathrm{W}$ Long), $0.8 \mathrm{~km} \mathrm{NE}$ of Ontario Northland Railway crossing over Hwys. 11 and 17. Sample overlay $24 \mathrm{~cm}$ massive silt above sorted fine- to medium-grained sand. 
GSC-843. Lake 'H'

$4640 \pm 160$

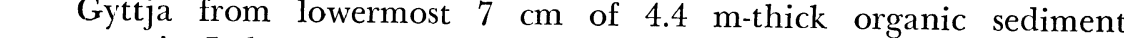
sequence in Lake ' $\mathrm{H}$ ', alt $204.2 \mathrm{~m}$, water depth $4.3 \mathrm{~m}\left(46^{\circ} 18^{\prime} 04^{\prime}\right.$ ' $\mathrm{N}$ Lat, $79^{\circ} 24^{\prime} 00^{\prime \prime} \mathrm{W}$ Long), $2.5 \mathrm{~km} \mathrm{E}$ of junction of Hwys. 11 and 17 . Sample overlay $19 \mathrm{~cm}$ clayey silt above sorted fine- to medium-grained sand.

\section{GSC-836. West Jennings Lake}

$4650 \pm 200$

Gyttja from lowermost $12 \mathrm{~cm}$ of $2.8 \mathrm{~m}$-thick organic sediment sequence in West Jennings Lake, alt $202.2 \mathrm{~m}$, water depth $7.1 \mathrm{~m}\left(46^{\circ} 17^{\prime}\right.$ $54^{\prime \prime} \mathrm{N}$ Lat, $79^{\circ} 25^{\prime} 48^{\prime \prime}$ W Long) on W side of Hwy. 11, $0.8 \mathrm{~km} \mathrm{~S}$ of junction of Hwys. 11 and 17. Sample overlay $23 \mathrm{~cm}$ silty sand with scattered plant fragments above pebbly sorted medium-grained sand.

\section{GSC-850. Depensier Lake}

$4490 \pm 180$

Gyttja from lowermost $6 \mathrm{~cm}$ of 2.4 m-thick organic sediment sequence in Depensier Lake, alt $202.3 \mathrm{~m}$, water depth $9 \mathrm{~m}\left(46^{\circ} 18^{\prime} 38^{\prime \prime}\right.$ $\mathrm{N}$ Lat, $79^{\circ} 25^{\prime} 03^{\prime \prime} \mathrm{W}$ Long), $1.9 \mathrm{~km} \mathrm{E}$ of Ontario Northland Railway crossing over Hwys. 11 and 17. Sample overlay clayey silt.

General Comment (C.F.M.L.): channels holding lake basins functioned, in part, as controlling thresholds for $\mathrm{E}$ drainage from early postglacial lakes in Nipissing and Georgian Bay Basins. During this period, water levels were stabilized at Nipissing beach level, here ca. $212 \mathrm{~m}$ a.s.l. Dates GSC-815 and -821, on basal gyttja from lakes at, or slightly above, this elevation, indicate that ice retreat and channel downcutting were essentially complete and drainage was stabilized prior to ca. 8300 B.P. All other sites lie in channel bottoms 5 to $10 \mathrm{~m}$ below Nipissing beach level; dates on basal organic material in them are minimum for last use of North Bay outlet or close of Nipissing I (3-outlet) phase (Lewis, 1969). NaOH-leach omitted from pretreatment of all samples; all were mixed with dead gas for counting. Date GSC-808 based on one 3-day count.

\section{Montreal River series}

Exploratory drilling at site of Ontario Hydro-Electric Comm. Lower

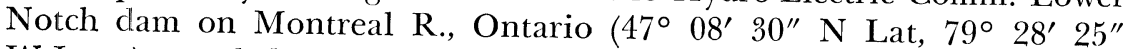
$\mathrm{W}$ Long) revealed a thick valley-fill sequence of river alluvium over compact stony gray till over organic sand and silt, and gravel. Date GSC-920 on organic fragments recovered during drilling was apparently spurious, so organic unit was resampled during excavation for dam.

\section{GSC-920. Montreal River (I)}

$19,800 \pm 1060$

mam from borehole, sample alt ca. $170 \mathrm{~m}, 34.9$ to $35.2 \mathrm{~m}$ below surface. Coll. 1967 by H. G. Acres Ltd., Niagara Falls; subm. by J. S. Scott. 
GSC-1299. Montreal River (II)

Waterworn wood (Picea sp., id by R. J. Mott) from sand and silt unit at alt ca. $182 \mathrm{~m}, 23 \mathrm{~m}$ below original surface. Coll. 1969 by J. S. Scott and R. G. Skinner.

General Comments (R.G.S.): GSC-920 is improbable as ice margin was then in N part of U.S. (Goldthwait et al., 1965). Gyttja clasts with GSC1299 contained many deciduous pollen including 30\% Quercus and 6\% Tilia (Skinner, 1971). Organic material is probably interglacial, but time of burial at Lower Notch is unknown; (W.B., Jr.): filaments and fibers, possibly of textile origin, were noted in GSC-920; although visible ones were removed by hand, remaining small sample $(6.0 \mathrm{~g}$, including some sand) may have been contaminated also. GSC-920 mixed with dead gas for counting. (One 3-day count.)

\section{Woodbridge series} Ontario.

Plant detritus and wood fragments from sites near Woodbridge,

\section{GSC-629-2. Woodbridge (I)}

$40,200 \pm 480$

Peaty sand and wood from gully eroded in floor of borrow pit, S of CNR bypass, $\mathrm{N}$ of Steeles Ave., W of Kysling Ave., near Woodbridge, Ontario (43 $46^{\prime} \mathrm{N}$ Lat, $79^{\circ} 36^{\prime} \mathrm{W}$ Long). Borrow pit excavated to ca. $6 \mathrm{~m}$ depth in 1962, gully cut in 1965. Site wet but nearly free of vegetation and coll. of peaty layer made away from modern grass, etc. Peat occurs in depression in clayey Sunnybrook till and is overlain, successively, by gravel and 3 tills. Coll. 1966 by P. F. Karrow. Two determinations were made:

GSC-629. One 3-day count in 5-L counter at 1 atm $>41,000$

GSC-629-2. One 4-day count and one 1-day count in 5 - $\mathrm{L}$ counter at $4 \mathrm{~atm}$

Comment (W.B., Jr.): as noted previously (Table 3, R., 1970, v. 12, p. 48) GSC-629 was prepared from wood only, whereas GSC-629-2 was prepared from wood plus plant detritus; presence of material younger than wood could account for high counter-pressure age appearing younger than low counter-pressure age. For Woodbridge dates it must be remembered that: 1) only $0.1 \%$ contamination of 45,000 yr-old material (cf. GSG-1181, this list) with contemporary carbon would cause an error in age of $2000 \mathrm{yr}$, and $1 \%$ contamination would cause an error of 10,000 yr (Olsson and Blake, 1962); 2) numerous dates show that mid-Wisconsin Port Talbot interstade was of at least 10,000 yr duration (cf. Dreimanis et al., 1966; McDonald, 1971), hence at any site material of varying age may occur. For either or both reasons slight variation between GSC-629-2 and GSC-1181 is not surprising. 
GSC-1181. Woodbridge (II)

$45,000 \pm 900$

Organic sediments, wood fragments, $\mathbf{4 3 , 0 5 0}$ в.c. gravel, exposed few $\mathrm{cm}$ below Steeles Ave. and ca. Lat, $79^{\circ} 35^{\prime} 30^{\prime \prime} \mathrm{W}$. $1.6 \mathrm{~km} \mathrm{~S}$ of Woodbridge, Ontario $\left(43^{\circ} 45^{\prime} 39^{\prime \prime} \mathrm{N}\right.$ Lat, $79^{\circ} 35^{\prime} 30^{\prime \prime} \mathrm{W}$ Long). Borrow pit last operated in 1963; original ground surface est. 5 to $6 \mathrm{~m}$ higher than at time of sampling. Coll. 1965 by $\mathrm{O}$. L. White, Univ. of Waterloo, Waterloo, ca. $2 \mathrm{~m}$ from site where a partial molar of woolly mammoth (Elephas [Mammuthus] primigenius) was recovered (Churcher, 1968); material believed to be same as that enclosing tooth. Organic material, silt, and overlying gravel appear to fill channels cut in underlying till (Sunnybrook) (cf. White, 1964; Dreimanis and Karrow, 1965). From relation to exposed sec. ca. $150 \mathrm{~m}$ $\mathrm{N}$, channel deposits are thought overlain by 3 tills. Some sheet and gully erosion occurred in 2-yr interval between excavation of pit and coll. of sample, but little plant growth developed on surface and sample believed uncontaminated. Comment (P.F.K.): date accepted for Thorncliffe Formation and believed better than GSC-629 or GSC-629-2 as GSC-1181 coll. earlier, thus less new plant growth developed in borrow pit. Date confirms assignment of organic to Port Talbot interstade and agrees closely with GrN-4454, 44,600 \pm 190 , on presumed correlative material from Markham, Ontario (cf. Karrow, 1969). (One 1-day count and one 3-day count in 5-L counter at $4 \mathrm{~atm}$.)

GSC-729. Woodbridge (III)

Plant detritus enclosed in sand an side of CNR tracks, W of in sand and silt from railway cut along $\mathrm{N}$ of Humber R. near Woodbridge, Ontario $\left(43^{\circ}\right.$ logically dist, $79^{\circ} 35^{\prime} 30^{\prime \prime} \mathrm{W}$ Long). Sampled unit overlain by 4 lithologically distinct till sheets, underlain by sand, gravel, and York Till (Illinoian). Coll. 1966 by A. Dreimanis and A. A. Berti, Univ. of Western Ontario, London, and J. Terasmae. Comment (J.T.): previous date, $>49,700$ yr (GSC-203; R., 1965, v. 7, p. 29, incorrectly given as GSC230 in Karrow, 1969, p. 9) was from base of sampled unit; present sample taken from top of $5 \mathrm{~m}$-thick unit to check possibility of mid-Wisconsin age for these plant-bearing beds (i.e., Port Talbot interstade; cf. Dreimanis et al., 1966). Both dates indicate that beds are equivalent to Scarborough Formation of Toronto area, a conclusion supported by pollen assemblages found in this unit. (One 1-day count and one 3-day count in 5 - $\mathrm{L}$ counter at $4 \mathrm{~atm}$.)

\section{Manitoulin District series}

The following dates on gyttja, coarse plant detritus and stump wood provide a recent history of Manitoulin Dist. emergence from Lake Huron. Gyttja was cored from deepest water of small lakes. Lake sediment samples GSC-558, -559 , and -904 coll. with a plastic tube push corer and GSC-568 and -569 taken 1965 with a Hiller peat borer by C. F. M. Lewis and J. Terasmae. All other gyttja samples coll. 1967 
by C. F. M. Lewis using a Livingstone piston corer. Most gyttja samples are composites from equivalent stratigraphic levels in 2 or more replicate cores. Elevations of lake water levels and sub-aerial samples determined by spirit levelling, relative to Canadian Geodetic Datum.

\section{GSC-558. Sucker Creek}

Gyttja from lowermost $15 \mathrm{~cm}$ of $1.7 \mathrm{~m}$-thick organic sediment sequence in small lake, alt $193.1 \mathrm{~m}$, water depth $0.3 \mathrm{~m}$, in shallow bedrock depression within Sucker Creek Indian Reserve, $5.6 \mathrm{~km} \mathrm{SW}$ of Little Current, Ontario ( $45^{\circ} 57^{\prime} 48^{\prime \prime}$ N Lat, 81 $59^{\prime} 28^{\prime \prime}$ W Long). Sample overlay pebbly (limestone) fine- to medium-grained gray sand.

\section{GSC-569. 'Upper Wikwemikongsing' $\quad 3850 \pm 160$ Lake, $2.5 \mathrm{~m} \quad 1900$ B.c.}

Coarse detritus gyttja from lowermost $8 \mathrm{~cm}$ of $2.0 \mathrm{~m}$-thick organic sediment sequence in 'Upper Wikwemikongsing' Lake, alt $194.7 \mathrm{~m}$, water depth $0.5 \mathrm{~m}\left(45^{\circ} 42^{\prime} 04^{\prime \prime} \mathrm{N}\right.$ Lat, $81^{\circ} 41^{\prime} 08^{\prime \prime} \mathrm{W}$ Long). Lake in depression behind Nipissing gravel bar. Sample overlay shelly lacustrine silty gray clay.

\section{GSC-568. 'Upper Wikwemikongsing' $\quad 5560 \pm 190$ Lake, $3.5 \mathrm{~m} \quad 3610$ B.c.}

Fine detritus gyttja from uppermost $8 \mathrm{~cm}$ of a lower organic sediment unit underlying $1.0 \mathrm{~m}$ of shelly lacustrine silty clay below $2.0 \mathrm{~m}$ coarse detritus gyttja, at same location as GSC-569.

GSC-904. 'Lower Wikemikongsing'

\section{Lake, $0.7 \mathrm{~m}$}

A.D. 1440

$510 \pm 180$

Silty plant detritus from basal $4 \mathrm{~cm}$ of $33 \mathrm{~cm}$-thick organic sediment sequence in 'Lower Wikwemikongsing' Lake, alt $178.0 \mathrm{~m}$, water depth $40 \mathrm{~cm}\left(45^{\circ} 42^{\prime} 38^{\prime \prime} \mathrm{N}\right.$ Lat, $81^{\circ} 39^{\prime} 48^{\prime \prime} \mathrm{W}$ Long), a small lake impounded behind sand bar and beach $\mathrm{N}$ of James Bay, Lake Huron. Sample overlay gray silty fine sand. Lake bottom is $50 \%$ covered by Chara sp.

GSC-559. 'Lower Wikwemikongsing'

$5820 \pm 180$ Lake, $2.0 \mathrm{~m}$

3870 B.c.

Coarse plant detritus from a $2 \mathrm{~cm}$-thick organic unit imbedded in gray silty sand unit at previous (GSC-904) sample site $202 \mathrm{~cm}$ beneath lake surface.

\section{GSC-1103. Deer Lake}

Sandy gyttja and detrital wood fragments from lowermost $5 \mathrm{~cm}$ of $2.8 \mathrm{~m}$-thick organic sediment sequence in Deer Lake, alt $196.4 \mathrm{~m}$, water depth $0.3 \mathrm{~m}\left(45^{\circ} 38^{\prime} 54^{\prime \prime} \mathrm{N}\right.$ Lat, $82^{\circ} 17^{\prime} 44^{\prime \prime} \mathrm{W}$ Long). Sample overlay 
silty sand. Deer Lake basin is impounded by a baymouth bar of Nipissing Great Lakes.

\section{GSC-1105. 'Rutherford' Lake}

$$
1500 \pm 160
$$

A.D. 450

$\delta C^{13}=-25.0 \%$

Sandy gyttja from basal $10 \mathrm{~cm}$ of $1.1 \mathrm{~m}$-thick organic sediment sequence in 'Rutherford' Lake, alt $181.4 \mathrm{~m}$, water depth $1.8 \mathrm{~m}\left(45^{\circ}\right.$ $59^{\prime} 30^{\prime \prime} \mathrm{N}$ Lat, $81^{\circ} 29^{\prime} 02^{\prime \prime} \mathrm{W}$ Long), ca. $5.8 \mathrm{~km} \mathrm{NE}$ of Killarney, Ontario beside Hwy 637. Sample overlay hard silt.

\section{GSC-1106. 'Lower Dean Bay' Lake}

$$
\begin{array}{r}
1660 \pm 150 \\
\text { A.D. } 290 \\
\delta G^{1 s}=-25.6 \% \text { o }
\end{array}
$$

Sandy gyttja from basal $3 \mathrm{~cm}$ of $36 \mathrm{~cm}$-thick organic sediment sequence in 'Lower Dean Bay' Lake, alt $182.9 \mathrm{~m}$, water depth $1.0 \mathrm{~m}$ $\left(45^{\circ} 41^{\prime} 30^{\prime \prime} \mathrm{N}\right.$ Lat, $82^{\circ} 19^{\prime} 17^{\prime \prime} \mathrm{W}$ Long). Sample overlay pebbly coarse sand. Lake is impounded between sand and shingle beach berms of recently emerged coast.

\section{GSC-1107. 'Upper Dean Bay' Lake}

$$
\begin{gathered}
2690 \pm 170 \\
\mathbf{7 4 0} \text { B.C. } \\
\delta C^{13}=-26.6 \% 0
\end{gathered}
$$

Sandy gyttja and plant detritus from lowermost $3 \mathrm{~cm}$ of $80 \mathrm{~cm}-$ thick organic sediment sequence in 'Upper Dean Bay' Lake, alt 186.8 $\mathrm{m}$, water depth $35 \mathrm{~cm}\left(45^{\circ} 41^{\prime} 47^{\prime \prime} \mathrm{N}\right.$ Lat, $82^{\circ} 18^{\prime} 42^{\prime \prime} \mathrm{W}$ Long). Sample overlay pebbly coarse sand. Lake is enclosed between sand and shingle beach berms of recently emerged coast.

\section{GSC-1108. 'Tehkummah' Lake}

$$
\begin{gathered}
10,150 \pm 190 \\
8200 \text { B.C. } \\
\delta C^{13}=-22.1 \% \circ
\end{gathered}
$$

Silty gyttja from basal $5 \mathrm{~cm}$ of $7.4 \mathrm{~m}$-thick organic sediment sequence in 'Tehkummah' Lake, alt $191.7 \mathrm{~m}$, water depth $0.4 \mathrm{~m}\left(45^{\circ}\right.$ $35^{\prime} 58^{\prime \prime} \mathrm{N}$ Lat, 81 $59^{\prime} 56^{\prime \prime} \mathrm{W}$ Long), ca. $7 \mathrm{~km} \mathrm{NE}$ of South Baymouth. Sample overlay gray silt.

\section{GSC-1109. Smokey Hollow Lake}

$$
\begin{gathered}
\mathbf{4 7 4 0} \pm \mathbf{1 4 0} \\
\mathbf{2 7 9 0} \text { B.C. } \\
\delta C^{13}=-25.3 \% 0
\end{gathered}
$$

Silty gyttja from basal $10 \mathrm{~cm}$ of $3.6 \mathrm{~m}$-thick upper organic sediment sequence in Smokey Hollow Lake, alt $192.7 \mathrm{~m}$, water depth $1.5 \mathrm{~m}\left(45^{\circ}\right.$ $38^{\prime} 04^{\prime \prime} \mathrm{N}$ Lat, $82^{\circ} 04^{\prime} 18^{\prime \prime} \mathrm{W}$ Long), $4.5 \mathrm{~km}$ N of Michael Bay. Sample overlay $2.7 \mathrm{~m}$ shelly silt over $0.5 \mathrm{~m}$ coarse plant detritus over silty sand. Dates on top (6270 \pm 190, I-4037) and bottom (9130 \pm 140 , I-4036) of lower plant detritus unit are discussed in Lewis (1969).

\section{GSC-869. Britainville}

$5530 \pm 130$

Piece of root (Larix sp., id. by R. J. Mott) from stump in situ on surface of compressed peat and leaf debris ca. $2 \mathrm{~km} \mathrm{~S}$ of Britainville, 
Ontario, alt $193.9 \mathrm{~m}\left(45^{\circ} 43^{\prime} 07^{\prime \prime} \mathrm{N}\right.$ Lat, $82^{\circ} 23^{\prime} 50^{\prime \prime} \mathrm{W}$ Long). Peat and stump overlain by $3 \mathrm{~m}$ stratified sand in a Nipissing Great Lakes baymouth bar, mantled with eolian fine sand. Peat, $1 \mathrm{~m}$ thick, is underlain by a sticky gray lacustrine clay containing scattered mollusk shells.

\section{GSC-1102. Dominion Bay}

A.D. 1760

$190 \pm 130$

$\delta C^{13}=-26.2 \%$

Plant detritus from $1 \mathrm{~cm}$-thick seam, $108 \mathrm{~cm}$ below crest of sandy modern storm beach berm at Dominion Bay, S coast of Manitoulin I., alt $177.4 \mathrm{~m}\left(45^{\circ} 42^{\prime} 24^{\prime \prime} \mathrm{N}\right.$ Lat, $82^{\circ} 25^{\prime} 14^{\prime \prime} \mathrm{W}$ Long). Plant detritus overlies pebbles and cobbles of thin lag deposit developed on eroded surface of underlying till.

General Comment (G.F.M.L.): GSC-1108 and -568 date range, ca. 10,000 to 5500 yr в.P., for emergence of Manitoulin I., establishment of low lake levels, and subsequent rise of Huron Basin waters to Nipissing shoreline during Algonquin to Nipissing interval (Lewis, 1969). GSC869 and -1103 are intimately related to shore features of Nipissing Great Lakes and provide a good estimate, 5400 to 5900 yr B.P., for maximum transgression of this lake phase in Huron Basin. Remaining dates indicate uniform uplift for Manitoulin I., relative to Lake Huron outlet area at Sarnia, Ontario, of $2.8 \pm 0.8 \mathrm{~mm} / \mathrm{yr}$ during past 5000 radiocarbon yr (Lewis, 1970). NaOH-leach omitted from pretreatment of all samples except GSC-559 and -869. All samples mixed with dead gas for counting except GSC-869, -1102, and -1103. Dates GSC-559, -568, -869, $-1103,-1108$, and -1109 each based on one 3-day count.

GSC-1185. Albany River

$>54,000$

Compressed peat interstratified with "blue" clay from $7.5 \mathrm{~m}$ below surface in river-bank exposure on island in Albany R., Ontario $\left(51^{\circ}\right.$ $57^{\prime} 20^{\prime \prime} \mathrm{N}$ Lat, $82^{\circ} 32^{\prime} 00^{\prime \prime} \mathrm{W}$ Long), alt ca. $35 \mathrm{~m}$. Peat overlain by 4.5 $\mathrm{m}$ of "blue" clayey till, and underlain by at least $4 \mathrm{~m}$ of dark brownblack till. Coll. 1968 by R. G. Wilkins, Ontario Water Resources Comm., Toronto; subm. by B. C. McDonald. Comment (B.C.M.): peat believed correlative with Quaternary Missinaibi beds, exposed in many places in Hudson Bay Lowland, for which only infinite dates are available (McDonald, 1969; 1971). Pretreatment included cold NaOH-leach. (One 1-day count and one 3-day count in 5-L counter at $4 \mathrm{~atm}$.)

\section{Manitoba}

\section{B. Western Canada}

\section{Churchill series}

Marine pelecypod shells and peat from near Churchill, Manitoba. GSC-682, -683, -684, -685, -723, -735 on samples coll. 1966 by B. G. Craig from various alts to determine late postglacial rate of isostatic readjustment; all but GSC-735 on Mytilus edulis in beach sediments. 
GSC-245. Churchill, peat

$3080 \pm 130$

Peat from base of shallow muskeg, overlying alluvial sand and gravel and marine sediments, right bank of Churchill R., near CNR tracks, W of airport and S of town site (ca. $58^{\circ} 45^{\prime} 10^{\prime \prime} \mathrm{N}$ Lat, $94^{\circ} 08^{\prime}$ W Long), alt ca. 4.5 to $5 \mathrm{~m}$. Coll. 1948 by N. W. Radforth, McMaster Univ., Hamilton, now at Univ. of New Brunswick, Fredericton; subm. by J. 'Terasmae.

GSC-261. Churchill, Mytilus edulis, $23 \mathrm{~m}$

$3040 \pm 130$

Whole shells and fragments from gravel and sand, W side of airport (ca. 58 $44^{\prime} 30^{\prime \prime} \mathrm{N}$ Lat, $94^{\circ} 04^{\prime} 50^{\prime \prime} \mathrm{W}$ Long), alt ca. $23 \mathrm{~m}$. Coll. 1948 by E. B. Owen; subm. by J. G. Fyles.

GSC-685. Churchill, Mytilus edulis, $38.5 \mathrm{~m}$

$3180 \pm 140$

From gravel in ditch, between Twin Lakes, $26.7 \mathrm{~km}$ SE of CNR sta. (58 $38^{\circ} 08^{\prime \prime} \mathrm{N}$ Lat, $93^{\circ} 48^{\prime} 40^{\prime \prime} \mathrm{W}$ Long), alt $38.5 \mathrm{~m}$.

GSC-683. Churchill, Mytilus edulis, $27 \mathrm{~m}$

$2320 \pm 130$

370 B.C.

From sandy gravel in ditch, Twin Lakes rd., $20.3 \mathrm{~km}$ ESE of CNR sta. (58 $42^{\prime} 10^{\prime \prime} \mathrm{N}$ Lat, $93^{\circ} 50^{\prime} 35^{\prime \prime} \mathrm{W}$ Long), alt $27 \mathrm{~m}$.

GSC-723. Churchill, Mytilus edulis, $22 \mathrm{~m}$

$$
2120 \pm 130
$$

From sand in gravel pit, Rocket Range rd., $10.9 \mathrm{~km} \mathrm{E}$ of CNR sta. (58 $45^{\prime} 25^{\prime \prime} \mathrm{N}$ Lat, $93^{\circ} 58^{\prime} 50^{\prime \prime} \mathrm{W}$ Long), alt $22 \mathrm{~m}$.

GSC-682. Churchill, Mytilus edulis, $10.5 \mathrm{~m}$

$1240 \pm 130$

From gravel in ditch, Rocket Range rd., $19.5 \mathrm{~km} \mathrm{E}$ of CNR sta. ( $58^{\circ} 44^{\prime} 45^{\prime \prime} \mathrm{N}$ Lat, $93^{\circ} 50^{\prime} 25^{\prime \prime}$ W Long), alt $10.5 \mathrm{~m}$.

GSC-684. Churchill, Mytilus edulis, $6.5 \mathrm{~m}$

$$
1020 \pm 140
$$

From pebbly sand in pit, Rocket Range rd., $13 \mathrm{~km} \mathrm{E}$ of CNR sta. (58 $45^{\circ} 35^{\prime \prime} \mathrm{N}$ Lat, $93^{\circ} 57^{\prime} 00^{\prime \prime} \mathrm{W}$ Long), alt $6.5 \mathrm{~m}$.

GSC-735. Churchill, shells, $4.6 \mathrm{~m}$

$3430 \pm 140$

Fragments of marine shells (Chlamys islandicus, Astarte banksii, Clinocardium ciliatum, Mytilus edulis, Hiatella arctica, Mya sp., Hemithyris psittacea, and Balanus sp.) from channel in stony silty clay dug in river bed, mouth of Goose Creek, Churchill R., $10.6 \mathrm{~km} \mathrm{SE}$ of CNR sta. (58 $48^{\prime} 15^{\prime \prime} \mathrm{N}$ Lat, $94^{\circ} 10^{\prime} 12^{\prime \prime} \mathrm{W}$ Long), alt $4.6 \mathrm{~m}$. 


\section{GSC-1226. Cape Churchill, Mytilus edulis, 0 m}

\section{A.D. 1950}

$\mathbf{0} \pm 130$

$\delta C^{13}=+1.9 \%$

From bottom in intertidal zone Cape Churchill, $58 \mathrm{~km} \mathrm{E}$ of

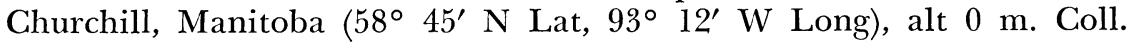
1967 by B. G. Craig.

General Comment (B.G.C.): 5 dates on Mytilus edulis shells from emerged strandline sediments, GSC-685,- $683,-723,-682$, and -684, plus GX-1065, $2800 \pm 110$, alt $38 \mathrm{~m}$ (Wagner, 1967) indicate that for period ca. 3000 to $1000 \mathrm{yr}$ ago land around Churchill rose relative to sea at rate of ca. $1.5 \mathrm{~m} / 100 \mathrm{yr}$ (Craig, 1969). GSC-245, -261, and -735 are anomalous, and may represent deposition in deep water, redeposition of older material, or a mixture of materials of various ages. GSC-1226 confirms modern age of recently living shells (some still attached). GSC-685 and -735 each mixed with dead gas for counting; one 3-day count each. (GSC-682, -683, and -1226 each based on one 3-day count.)

\section{GSC-1319. Rossendale}

$12,100 \pm 160$

\section{0,150 в.C.}

Peat moss (Scorpidium scorpioides, id. by M. Kuc), S side of reservoir $3.2 \mathrm{~km} \mathrm{~S}$ and $1.6 \mathrm{~km} \mathrm{E}$ of Rossendale, Manitoba (in E-W rd. allowance, SW $1 / 4$, sec. 23, tp. 9, rge. 9, W Prin. Mer. (49 $47.0^{\prime} \mathrm{N}$ Lat, $98^{\circ} 35.6^{\prime} \mathrm{W}$ Long), at alt $320 \pm 2 \mathrm{~m}$. Sample near $\mathrm{W}$ end and 0.3 to $0.6 \mathrm{~m}$ below surface on crest of spoil pile made during excavation of reservoir in 1952. Coll. 1969 by J. A. Elson, McGill Univ., Montreal. Comment (J.A.E.): sample is duplicate of Y-165, 12,400 \pm 420 (Preston et al., 1955), coll. 1952 by Elson and considered too old. Peat on spoil pile is from bottom of reservoir ca. $4 \mathrm{~m}$ deep, already filled with water when first visited, a few days after completion. An auger hole just W of reservoir penetrated ca. $1.5 \mathrm{~m}$ sandy and silty alluvium, overlying ca. $2 \mathrm{~m}$ clay with fragments of wood, charcoal, and snail shells near base, $0.6 \mathrm{~m}$ sandy clay, and $0.2 \mathrm{~m}$ fine brown sand similar to that assoc. with peat on spoil pile; ingress of water prevented further boring. Peat is typical of subarctic and $\mathrm{N}$ parts of Boreal Forest and grows in shallow, trophic, still, rather small ponds surrounded by bogs or fens, but not by forest (M. Kuc, written commun.). Peat accumulated in a gully formed in Assiniboine delta during an early low-water phase of Lake Agassiz (Elson, 1967). Gully was subsequently submerged during a higher stand of lake, possibly at Norcross strandline, and was exposed again as lake receded. Upper part of gully system was later captured by a small tributary of Assiniboine R.; lower part was blocked by sand dunes formed along Campbell strandline. Date confirms Y-165 and supports concept of early extensive phase of Lake Agassiz while stagnant ice existed on plains to $\mathrm{W}$ and $\mathrm{S}$. Additional support is given by date I-1682, 12,800 \pm 350 , on basal gyttja (9.8 $\mathrm{m}$ depth) in lake in Tiger Hills $64 \mathrm{~km}$ to SW (Ritchie and Lichti-Federovich, 1968). 


\section{Brookdale Road series}

Humus-rich sand from Ah horizon of 5 buried Chernozem soils exposed in roadcut through $\mathrm{N}$ wing of stabilized dune of Brandon Sand Hills along rd. (W side) to Brookdale, $2.56 \mathrm{~km} \mathrm{~N}$ of Trans-Canada Hwy ca. $8 \mathrm{~km}$ ENE of Douglas Sta., Manitoba $\left(49^{\circ} 55^{\prime} 30^{\prime \prime} \mathrm{N}\right.$ Lat, 99 $35^{\prime} 25^{\prime \prime}$ W Long). Paleosols separated by beds of humus-free sands occur in ca. $2.8 \mathrm{~m}$ of dune sand overlying sediments of Assiniboine delta of Lake Agassiz (Elson, 1960). Samples coll. 1967 by P. P. David, Univ. of Montreal, Montreal (except GSC-1091, coll. 1968 by L. A. Jaskula, Carleton Univ., Ottawa) to date Holocene eolian activity and to trace past periods of drought.

GSC-1091. Brookdale Road, $0.52 \mathrm{~m}$ depth A.D. 1520

Date uncorrected for isotopic fractionation: $340 \pm 130$.

$\delta C^{13}=-19.3 \%$

\section{GSC-954. Brookdale Road, $0.73 \mathrm{~m}$ depth}

Uncorrected date: $820 \pm 140$.

\section{GSC-953. Brookdale Road, $1.28 \mathrm{~m}$ depth}

Uncorrected date: $1480 \pm 150$.

\section{GSC-950. Brookdale Road, $1.82 \mathrm{~m}$ depth}

Uncorrected date: $2120 \pm 150$.

\section{GSC-949. Brookdale Road, $2.35 \mathrm{~m}$ depth}

Uncorrected date: $3710 \pm 180$.

$$
920 \pm 140
$$$$
\text { A.D. } 1030
$$$$
\delta C^{13}=-18.4 \%
$$

$$
\begin{aligned}
& \mathbf{1 5 1 0} \pm 150 \\
& \text { A.D. } 440 \\
& \delta C^{13}=-22.9 \% \circ
\end{aligned}
$$

$$
\begin{gathered}
2150 \pm 150 \\
200 \text { B.C. } \\
\delta C^{13}=-22.9 \% \circ
\end{gathered}
$$

$3680 \pm 180$ 1730 B.C.

$\delta C^{13}=-27.0 \%$

General Comment (P.P.D.): humic matter extracted by flotation in distilled water, from sandy soil previously cleaned of plant roots under binocular microscope, and excess water evaporated in porcelain dish over bunsen flame producing dry crust of humic concentrate. Each date corrected for isotopic fractionation (cf. R., 1970, v. 12, p. 50; Campbell et al., 1967a; Ruhe, 1969). Uncorrected dates are given because they are used in correlation with other uncorrected dates (David, ms. in preparation; Ritchie, 1969). Samples not chemically pretreated prior to dating; consequently dates represent mean residence time (M.R.T.) of total soil humus of sampled soil layer at time of soil burial (Campbell et al., 1967b). Dates may be slightly older than soil burial; but since all samples, except GSC-949 (5 cm below top of paleosol), were from upper 2 to $3 \mathrm{~cm}$ of paleosols, age discrepancy should be small (R., 1968, v. 10, p. 10-11). Soils were buried by subsequent dune activity produced 
by extended periods of drought (David, 1971). GSC-954 agrees with GSC976 (this list) and S-286 (R., 1968, v. 10, p. 372); GSC-953 with GSC-761 (R., 1968, v. 10, p. 219) and S-45 (R., 1960, v. 2, p. 80). GSC-950 overlaps with GSC-817 and -969 (this list) and GSC-579 (R., 1967, v. 9, p. 166); however, it dates younger episode of dune building (cf. comments for Harte Road series, below). NaOH-leach omitted from pretreatment of all samples. GSC-954, -953, -950 and -949 mixed with dead gas for counting. (GSC-1091, -954 and -949 each based on one 3-day count.)

\section{Harte Road series}

Humus-rich sandy matter from Ah horizon of 2 of 3 buried Chernozem soils exposed in 2 roadcuts through same wing of stabilized dune of Brandon Sand Hills, along opposite sides of road to Harte, Manitoba, $0.88 \mathrm{~km} \mathrm{~N}$ of Trans-Canada Hwy $8 \mathrm{~km} \mathrm{~W}$ of junction with Hwy 258 $\mathrm{S}$ to Carberry, Manitoba ( $49^{\circ} 54^{\prime} 35^{\prime \prime} \mathrm{N}$ Lat, 99 $28^{\prime} 35^{\prime \prime}$ W Long). GSC817 coll. 1966, others coll. 1967 by P. P. David.

\section{GSC-976. Harte Road, $1.3 \mathrm{~m}$ depth}

$$
\begin{aligned}
& \mathbf{8 9 0} \pm 130 \\
& \text { A.D. } 1060 \\
& \delta C^{13}=-21.7 \% \text { o }
\end{aligned}
$$

Uncorrected date: $830 \pm 130$. From $W$ roadcut. (One 3-day count.)

\section{GSC-981. Harte Road, $2.65 \mathrm{~m}$ depth}

$$
\begin{aligned}
& 2530 \pm 140 \\
& 580 \text { B.C. }
\end{aligned}
$$

Uncorrected date: $2480 \pm 140$. From $\mathrm{W}$ roadcut.

\section{GSC-817. Harte Road, $2.13 \mathrm{~m}$ depth}

From $\mathrm{E}$ roadcut.

General Comment (P.P.D.): preparation of GSC-976 and -981 same as for Brookdale Road series (above). GSC-817 based on bulk soil sample cleaned of plant roots. GSC-981 and -817, from stratigraphically same paleosol on opposite sides of road, closely agree. GSC-981 considered more reliable as contamination by humus from younger paleosol (not dated) directly overlying -817 may have rendered latter somewhat younger (R., 1968, v. 10, p. 10). Overlap of GSC-817 (uncorrected date only) with GSC-950 (above) does not indicate age agreement since uncontaminated -981 is beyond age range of -950 . GSC-976 agrees with GSC-954 (this list) and S-286 (R., 1968, v. 10, p. 372). GSC-981 and -817 agree with GSC-969 (this list), GSC-579 (R., 1967, v. 9, p. 166) and S-284 or -285 (R., 1968, v. 10, p. 372). Soils buried by subsequent dune activities produced by extended periods of drought. $\mathrm{NaOH}$-leach omitted from pretreatment of GSC-976 and -981; pretreatment of GSC-817 included cold $\mathrm{NaOH}-\mathrm{leach}$. All samples mixed with dead gas for counting.

\section{Carberry $\mathbf{S}$ series}

Humus-rich sandy matter from Ah horizon of 2 buried Chernozem soils exposed in roadcut through stabilized dune of Brandon Sand Hills, 
E side of Hwy 258 ca. $7.36 \mathrm{~km} \mathrm{~S}$ of Carberry, Manitoba $\left(49^{\circ} 47^{\prime} 25^{\prime \prime}\right.$ N Lat, $99^{\circ} 21^{\prime} 00^{\prime \prime}$ W Long). Coll. 1967 by P. P. David.

\section{GSC-970. Carberry S, 2.99 m depth}

Uncorrected date: $1860 \pm 130$.

\section{GSC-969. Carberry S, $3.20 \mathrm{~m}$ depth}

$$
\begin{array}{r}
1910 \pm 130 \\
\text { A.D. 40 } \\
\delta C^{13}=-21.5 \% \text { } \\
\mathbf{2 4 2 0} \pm \mathbf{1 4 0} \\
\mathbf{4 7 0} \text { B.C. } \\
\delta C^{1 s}=-21.0 \%
\end{array}
$$

Uncorrected date: $2350 \pm 140$. From top of lower, composite soil.

General Comment (P.P.D.): sample preparation same as for Brookdale Road series (this list). Paleosols are separated by thin sand layers; contamination of GSC-969, by humus from younger paleosol, may have rendered it younger than true age of burial (R., 1968, v. 10, p. 10). GSC-969 agrees with GSC-817 and -981 (this list), GSC-579 (R., 1967, v. 9, p. 166) and S-284 or S-285 (R., 1968, v. 10, p. 372). GSC-970 agrees with GSC-898 (R., 1970, v. 12, p. 67) and S-164 (R., 1965, v. 7, p. 230). Both soils buried by renewed eolian activity. NaOH-leach omitted from pretreatment of both samples; both mixed with dead gas for counting.

\section{Carberry NE series}

Humus-rich sandy matter with finely dispersed charcoal from Ah horizon of upper of 2 paleosols, and bones (Bison sp., id. by C. R. Harington, Natl. Mus. Nat. Sci., Ottawa) overlying upper paleosol exposed in roadcut through stabilized dune of Brandon Sand Hills, along $\mathrm{N}$ side of Trans-Canada Hwy $7.2 \mathrm{~km} \mathrm{E}$ of junction with Hwy $258 \mathrm{~S}$ to

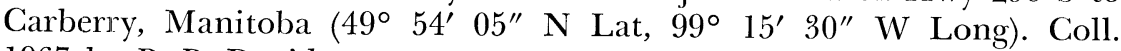
1967 by P. P. David.

\section{GSC-990. Carberry NE, bones}

$$
\begin{aligned}
& \quad 1260 \pm 130 \\
& \text { A.D. } 690 \\
& \delta C^{13}=-19.1 \%
\end{aligned}
$$

Uncorrected date: $1170 \pm 130$. Used 3 vertebrae $(357 \mathrm{~g})$ from dune sand containing some reworked humus. Bones apparently free of root hairs.

\section{GSC-931. Carberry NE, Ahb horizon}

$1200 \pm 140$

\section{A.D. 750}

$\delta C^{13}=-25.5 \%$

Bulk soil sample, freed from root hairs, at $2.56 \mathrm{~m}$ depth in dune. General Comment (P.P.D.): agreement between ages of stratigraphically related materials is excellent, considering that sand enclosing bones contained humic matter reworked from underlying paleosol. Bone possibly contaminated by older humic matter (R., 1966, v. 8, p. 471). Age of bones suggests they probably belonged to Bison bison bison (C. R. Harington, written commun.). Dates renewed eolian activity. NaOHleach omitted from pretreatment of both samples. GSC-931 mixed with dead gas for counting. 


\section{GSC-1081. Virden}

Debris consisting of twigs, bark, etc. from Assiniboine R. valley alluvium. Sample, from core $18 \mathrm{~m}$ below surface of flood plain near Virden, Manitoba, NW 1/4 LSD 7, sec. 32, tp. 10, rge. 25 W $1\left(49^{\circ} 53^{\prime}\right.$ $\mathrm{N}$ Lat, $100^{\circ} 50^{\prime} \mathrm{W}$ Long), is deepest obtained from Assiniboine Valley fill. Coll. 1968 by R. W. Klassen. Comment (R.W.K.): dates early phase of valley filling after building of Assiniboine Delta (cf. Klassen, 1969). $\mathrm{NaOH}-$ leach omitted from sample pretreatment. Small sample $(7.2 \mathrm{~g})$ mixed with dead gas for counting, in 2-L counter at $1 \mathrm{~atm}$.

\section{Saskatchewan}

\section{GSC-1332. 'Empress Bluff'}

$10,500 \pm 180$

Fresh-water gastropod shells (Lymnaea elodes Say, id. by A. H. Clarke, Jr., Natl. Mus. Nat. Sci. Ottawa) from E bank South Saskatchewan R., ca. $11.5 \mathrm{~km}$ SSE of Empress, Alberta, in LSD 14 of sec. 4, tp. 22, rge. 29 , W 3rd mer. ( $50^{\circ} 50^{\prime} 50^{\prime \prime} \mathrm{N}$ Lat, $109^{\circ} 58^{\prime} 00^{\prime \prime} \mathrm{W}$ Long), alt ca. $715 \mathrm{~m}$. Shells from $2.1 \mathrm{~m}$ below prairie surface, $120 \mathrm{~m}$ above river, from lake silt overlying varved silt and clay and 0.3 to $1 \mathrm{~m}$ below a thick buried soil. Coll. 1969 by C. S. Churcher, Univ. of Toronto, Toronto, and A. M. Stalker. Comment (A.M.S.): dates last phase of proglacial ponding in area and maximum age for postglacial soil. Only outer $5 \%$ of shell removed by leaching. Sample mixed with dead gas for counting. (One 3-day count.)

\section{Alberta}

\section{Elkwater series}

Buried soils coll. 1966 by P. D. Jungerius, Univ. of Amsterdam, Amsterdam, The Netherlands.

\section{GSC-753. Elkwater, buried soil, $45 \mathrm{~cm}$}

$$
1250 \pm 130
$$

$4 \mathrm{Al}$ surface horizon of buried $5 \mathrm{~cm}$ thick black Chernozem soil (lowest of four) overlain by $45 \mathrm{~cm}$ alluvium, in streambank on $\mathrm{S}$ pediment of Cypress Hills, ca. $16 \mathrm{~km} \mathrm{~S}$ of Elkwater, Alberta in LSD 4 of sec. 4, tp. 7 , rge. 2 , W 4 th mer. $\left(49^{\circ} 31^{\prime} 30^{\prime \prime} \mathrm{N}\right.$ Lat, $110^{\circ} 13^{\prime} 48^{\prime \prime} \mathrm{W}$ Long), alt $1205 \mathrm{~m}$. Comments (P.D.J.): soil not as well developed as at GSC-800 site (this list), but represents period of landscape stability; (W.B., Jr.); cf. GSC-931 (1200 \pm 140$)$, Ahb horizon of buried soil, and GSC-990 (1260 \pm 130 ; Bison sp. bone) from NE of Carberry, Manitoba (both corrected dates, this list). Pretreatment, made in lab of former Geographical Branch under M. J. J. Bik, involved: addition of solution of sodium pyrophosphate $\left(\mathrm{Na}_{2} \mathrm{P}_{2} \mathrm{O}_{7} \cdot 2 \mathrm{H}_{2} \mathrm{O}\right)$ to soil sample, stirring with ultrasonic stirrer to cause formation of gel, sieving, through $53 \mu$ mesh or smaller while ultrasonic stirrer operating (rootlets, etc. being retained on sieve), evaporation of remainder causing organic material to form 
scale (subm. to $\mathrm{C}^{14}$ lab) above clay. $\mathrm{NaOH}$-leach omitted from pretreatment. (One 3-day count).

\section{GSC-800. Elkwater, buried soil, $70 \mathrm{~cm}$}

$3950 \pm 130$

Buried A horizon of paleosl beneall 2000 B.C. on Battle Creek paleosol beneath ca. $70 \mathrm{~cm}$ alluvium exposed on Battle Creek, ca. $16 \mathrm{~km} \mathrm{E}$ of Elkwater, Alberta, in LSD 5 of sec. 22, tp. 8, rge. 1, W 4th mer. (49 $39^{\prime} 40^{\prime \prime} \mathrm{N}$ Lat, $110^{\circ} 04^{\prime} 18^{\prime \prime} \mathrm{W}$ Long), alt ca. $1205 \mathrm{~m}$. Comments (P.D.J.): date closely agrees with age of charcoal from Indian campsite assoc. with paleosol, $3880 \pm 165$ (I-2428) and with date, $3610 \pm 100$ (I-2609), on organic matter of buried black Chernozem ([III] 2Al horizon, 61 to $69 \mathrm{~cm}$ depth) from nearby alluvial fan in Battle Creek valley (Jungerius, 1969; cf. also Andrews, 1967; R., 1970 , v. 12, p. 121). Dates time of erosional stability and soil formation; (W.B., Jr.): cf. GSC-949, $3680 \pm 180$ (corrected), this list, on lowest of 5 buried soils near Brookdale, Manitoba. Pretreatment (NaOH-leach omitted) as described above for GSC-753.

\section{GSC-1101. Elkwater Lake}

$5100 \pm 280$

Clayey organic marl from 365 to $375 \mathrm{~cm}$ below mud/water interface in ca. $9 \mathrm{~m}$ water, Elkwater Lake, $\mathrm{N}$ side of Cypress Hills ca. 48 $\mathrm{km}$ SE of Medicine Hat, Alberta $\left(49^{\circ} 40^{\prime} \mathrm{N}\right.$ Lat, $110^{\circ} 18^{\prime} \mathrm{W}$ Long) alt ca. $1235 \mathrm{~m}$. Coll. 1968 by J. Terasmae and R. J. Mott. Comment (R.J.M.): date on organic fraction is much younger than anticipated for abandonment of local glacial spillway. Possible explanations are: 1) basal organic sediments were not reached during sampling; 2) organic accumulation did not begin immediately after abandonment of spillway; 3) lake not formed until much later, as evidence of large-scale slumping along spillway suggests lake developed when a slump block dammed drainage. $\mathrm{NaOH}-\mathrm{leach}$ omitted from sample pretreatment. Sample mixed with dead gas for counting in 2-L counter at $1 \mathrm{~atm}$.

\section{Medicine Hat series (IV)}

Samples from 'Bain Bluff' on SE bank S Saskatchewan R., ca. 11 $\mathrm{km}$ NE of Medicine Hat, $5 \mathrm{~km}$ E of 'Mitchell Bluff', Alberta, on former Bain homestead; LSD 13 of sec. 36 , tp. 13 , rge. 5 , W 4 th mer. $\left(50^{\circ} 08^{\prime}\right.$ $05^{\prime \prime} \mathrm{N}$ Lat, $110^{\circ} 34^{\prime} 20^{\prime \prime} \mathrm{W}$ Long), alt ca. $745 \mathrm{~m}$. From near top of bluff, in silty alluvium containing 4 well-developed and some less-developed soils, Mazama volcanic ash ca. $6600 \mathrm{yr}$ old between topmost and 2nd youngest of well-developed soils, and an archaeologic site between ash and youngest soil. Alluvium was deposited in $21 \mathrm{~m}$-deep valley tributary to early postglacial stage of South Saskatchewan R.

\section{GSC-1302. 'Bain Bluff', charcoal}

$$
\begin{aligned}
& 1110 \pm 140 \\
& \text { A.D. 840 } \\
& \delta C^{13}=-23.4 \%
\end{aligned}
$$

Charcoal, $3.3 \mathrm{~g}$, from hearth immediately below uppermost welldeveloped soil, above Mazama ash bed, 0.6 to $1 \mathrm{~m}$ below surface. Coll. 1969 by L. O. Lindoe, Medicine Hat, Alberta; subm. by A. M. Stalker. 
GSC-1341. 'Bain Bluff', upper shells

6170 B.C.

Gastropod shells from between 2nd and 3rd lowest of 4 welldeveloped soils, ca. $2.5 \mathrm{~m}$ below surface. Coll. 1969 by A. M. Stalker.

\section{GSC-1061. 'Bain Bluff', lower shells}

$10,200 \pm 240$

8250 B.C.

Gastropod shells from between till and lowest of 4 well-developed soils, $3.7 \mathrm{~m}$ below surface. Coll. 1968 by A. M. Stalker.

General Comment (A.M.S.): dates and age of ash bed are internally consistent; they give maximum ages for initial development of 1st, 3rd, and 4th (from base) major soil-forming episodes in region and for time of man's occupation of site. They also are minimum for retreat of last glacier, and give level of South Saskatchewan R. when tributary valley was being cut. Pretreatment of GSC-1302 included cold $\mathrm{NaOH}$ leach. All 3 samples mixed with dead gas for counting.

\section{Medicine Hat series ( V)}

\section{GSC-1370. 'Evilsmelling Bluff'}

Wood fragments from E bank of South Saskatchewan R., ca. $5 \mathrm{~km}$ $\mathrm{N}$ of Medicine Hat, Alberta, in SE 1/4 sec. 20, tp. 13, rge 5, W 4th mer. $\left(50^{\circ} 06^{\prime} \mathrm{N}\right.$ Lat, $110^{\circ} 38^{\prime} \mathrm{W}$ Long), alt ca. $690 \mathrm{~m}$. Rare wood and plant fragments scattered in silt and clay ca. $5.5 \mathrm{~m}$ below top of 'Evilsmelling Band' and ca. $55 \mathrm{~m}$ above river. Band overlain by $18 \mathrm{~m}$ drift including 2 tills. Coll. 1969 by A. M. Stalker. Comment (A.M.S.): date internally consistent with, and corroborates, GSC-205, 24,490 \pm 200 (R., 1965, v. 7, p. 31), from higher in 'Evilsmelling Band', and GSC-578, 28,630 \pm 800 (R., 1967, v. 9, p. 168), from ca. $5 \mathrm{~m}$ lower. Dates indicate a deposition rate of ca. $15 \mathrm{~cm} /$ century for 'Evilsmelling Band', thought to be a flood-plain deposit laid down during very cold conditions. Sample mixed with dead gas for counting. (One 4-day count.)

\section{GSC-1044. 'Mitchell Bluff'}

Wood fragments coll. during bulldozing before excavation for bones, at NW end 'Mitchell Bluff', on S bank Saskatchewan R. $9.5 \mathrm{~km} \mathrm{~N}$ of Medicine Hat, Alberta; NE 1/4 sec. 32 , tp. 13 , rge. 5 , W 4 th mer. $\left(50^{\circ}\right.$ $07^{\prime} 45^{\prime \prime} \mathrm{N}$ Lat, $110^{\circ} 38^{\prime} 40^{\prime \prime} \mathrm{W}$ Long) alt ca. $685 \mathrm{~m}$. Wood $5 \mathrm{~m}$ below surface, $12 \mathrm{~m}$ above so-called 'Artifact Band', and $9 \mathrm{~m}$ in from cliff face in inter-till fine silt and clay containing scattered bones. Coll. 1968 by L. M. Kisko, Welland, Ontario, and A. M. Stalker. Comment (A.M.S.): 'Artifact band' previously dated at >30,000, (GSC-780; R., 1968, v. 10, p. 219). Other dates in series include GSC-704, -802, and -805 (ibid.) and GSC-543 and -578 (R., 1967, v. 9, p. 168-169). (One 3-day count.)

GSC-1233. Talber Bluff

Wood from W bank Oldman R. at Taber Bluff, $14.5 \mathrm{~km} \mathrm{~N}$ of Taber, Alberta; NW 1/4 sec. 19, tp. 11, rge. 16, W 4th mer. $\left(49^{\circ} 55^{\prime}\right.$ 
$45^{\prime \prime} \mathrm{N}$ Lat, $112^{\circ} 11^{\prime} \mathrm{W}$ Long), alt ca. $760 \mathrm{~m}$. Wood, $18 \mathrm{~m}$ below surface and ca. $30 \mathrm{~m}$ above river, from sandy alluvium of Unit $\mathrm{F}$ of Taber Sec. described by Stalker (1963), and from beneath one till sheet (Unit G, ibid). Coll. 1968 by A. M. Stalker. Comment (A.M.S.): sample thought to be from bed that yielded 'Taber Child' at 'Stalker Site', and to give minimum age for those human bones (cf. Stalker, 1969). It also indicates existence of only a single Late Wisconsin till sheet in area. Sample from $90 \mathrm{~m} \mathrm{~N}$, and $4.5 \mathrm{~m}$ below, wood used for S-65, >32,000 (R., 1960, v. 2, p. 75); see also GSC-888, $>37,000$ (R., 1970, v. 12, p. 67), probably from same bed. (Four 1-day counts in 5-L counter at 4 atm.)

\section{Lofty Lake series}

Lake sediment from $\mathrm{N}$ bay of Lofty Lake, ca. $21 \mathrm{~km} \mathrm{E}$ of Donatville, Alberta (54 $44^{\prime} \mathrm{N}$ Lat, $112^{\circ} 29^{\prime} \mathrm{W}$ Long), alt $625 \mathrm{~m}$, water depth $6.7 \mathrm{~m}$. Coll. 1968 with Livingstone corer by J. Terasmae and R. J. Mott.

\section{GSC-1201. Lofty Lake, 156 to $164 \mathrm{~cm}$}

Brown-green algal gyttja.

\section{GSC-1202. Lofty Lake, 290 to $298 \mathrm{~cm}$}

Buff to dark brown laminated gyttja.

\section{GSC-1234. Lofty Lake, 436 to $444 \mathrm{~cm}$}

Buff to dark brown laminated gyttja.

\section{GSC-1240. Lofty Lake, 512 to $518 \mathrm{~cm}$}

Buff: to dark brown laminated gyttja.

\section{GSC-1049. Lofty Lake, 549 to $554 \mathrm{~cm}$}

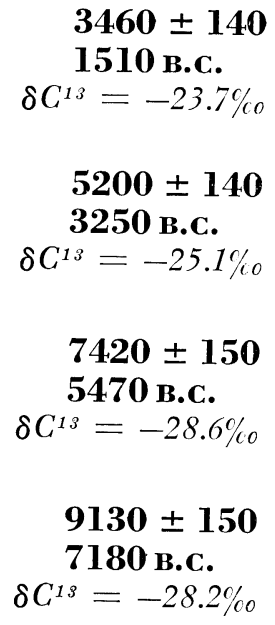

$3460 \pm 140$

1510 B.c.

$\delta C^{13}=-23.7 \%$

$5200 \pm 140$

3250 B.C.

$\delta C^{13}=-25.1 \%$

$7420 \pm 150$

5470 B.C.

$\delta C^{13}=-28.6 \%$

$9130 \pm 150$

7180 B.c.

$\delta C^{18}=-28.2 \%$

$11,400 \pm 190$

9450 B.c.

Basal gray-brown laminated gyttja overlying light gray silty clay.

General Comments (R.J.M., D.A.St-O.): date on basal gyttja is minimum for deglaciation and is oldest in region; cf. GSC-1093, 10,700 \pm 170 (St-Onge, 1970); GSC-1053, 10,400 \pm 200 , this list; (S. L-F.): GSC1240 dates spruce decline and birch rise (Zone II/III boundary), GSC1234 dates rise of grasses and pine (Zone III/IV boundary), GSC-1202 is at Hypsithermal maximum, and GSC-1201 dates Zone IV/V boundary. GSC-1234 and GSC-1240 pub. as $7480 \pm 150$ and $9180 \pm 150$, respectively, prior to corrections for isotopic fractionation (Lichti-Federovich, 1970). $\mathrm{NaOH}-\mathrm{leach}$ omitted from pretreatment of all samples. GSC-1049, -1201, -1202, and -1240 mixed with dead gas for counting. Dates GSC-1049 and GSC-1240 based on one 2-day and one 3-day count, respectively. 


\section{GSC-1093. 'Alpen Siding Lake'}

$$
\begin{aligned}
& 10,700 \pm 170 \\
& 8750 \text { B.c. }
\end{aligned}
$$

Basal marly gyttja from 380 to $385 \mathrm{~cm}$ below mud/water interface in ca. $1 \mathrm{~m}$ water in small lake on fluted till plain, ca. $3 \mathrm{~km} \mathrm{NW}$ of Alpen Siding and $35 \mathrm{~km} \mathrm{SE}$ of Athabasca, Alberta $\left(54^{\circ} 27^{\prime} \mathrm{N}\right.$ Lat, $113^{\circ}$ $00^{\prime} \mathrm{W}$ Long), alt $685 \mathrm{~m}$. Coll. 1968 by J. Terasmae and R. J. Mott. Comment (R.J.M.): date is minimum for deglaciation of area (St-Onge, 1970). NaOH-leach omitted from sample pretreatment. Sample mixed with dead gas for counting.

\section{GSC-1132. Beverly site, Edmonton}

$4920 \pm 330$

2970 B.c.

Ahg horizon of paleosol (humic gleysol) below $50+\mathrm{cm}$ of soil and alluvium in gravel pit on terrace of, and 6 to $9 \mathrm{~m}$ above, North Saskatchewan R. in NE (Beverly Dist.) Edmonton, Alberta, NW 1/4, sec. 6 , tp. 53, rge. 23 , W 4th mer. (53 $32^{\prime} \mathrm{N}$ Lat, $113^{\circ} 27^{\prime} \mathrm{W}$ Long). Exposed face fresh, with no plant growth, but roots from surface penetrated dated horizon. Ahg horizon underlain by alluvium in which Mazama ash layer, ca. 6600 yr old, occurs (Westgate et al., 1970; Pawluk and Dumanski, 1970). Coll. 1968 by S. Pawluk, Univ. of Alberta, Edmonton. Comment (S.P.): date agrees with interpretation of ash as Mazama. Pretreatment (by subm., no further treatment in $\mathrm{C}^{14} \mathrm{lab}$ ) to obtain humic acid fraction $(\sim 0.8 \mathrm{~g})$ from air-dried paleosol included: $0.1 \mathrm{~N}$ Na-pyrophosphate $+0.1 \mathrm{~N} \mathrm{NaOH}$ extraction, precipitation with $\mathrm{HCl}$, purification by dialysis against an H-saturated exchange resin (Dowex W50-X12), then freeze-drying in H-form. Root hairs, etc., removed by flotation prior to sedimentation treatment. Sample mixed with dead gas for counting.

\section{GSC-1209. Calgary}

$8080 \pm 150$

6130 B.C. lacustrine clayey silt; exposed in excavation (Mona Lisa site) at 17 th Ave. and 7 th St., S.W., Calgary, Alberta $\left(51^{\circ} 02^{\prime} \mathrm{N}\right.$ Lat, $114^{\circ} 05^{\prime} \mathrm{W}$ Long). A $7.5 \mathrm{~cm}$ volcanic ash layer (Mazama?) was ca. $0.3 \mathrm{~m}$ above bone horizon. Coll. 1968 by N. W. Rutter. Comment (N.W.R.): clayey silt probably deposited in lake in former flood plain of Bow R. Pretreatment incl. 24-hr NaOH-leach.

\section{GSC-1129. Duffield, buried soil}

$$
21,700 \pm 840
$$

Buried Ah horizon at max. $1 \mathrm{~m}$ depth, overlain by coarse-textured alluvium and present-day soil. Sample from fresh exposure on upper terrace of Saskatchewan R., $13.7 \mathrm{~km}$ SSE of Duffield, Alberta $\left(53^{\circ} 24^{\prime}\right.$ $\mathrm{N}$ Lat, $114^{\circ} 18^{\prime} \mathrm{W}$ Long). Coll. 1968 by S. Pawluk. Comment (S.P.): date does not fit geologic setting (cf. GSC-767, $8320 \pm 140$; R., 1968, v. 10, p. 221) and suggests part of organic contribution may be from lignite that crops out in vicinity. Although coal not discernible in dated 
sample, humification to form soil humus is very likely. It is impossible to differentiate coal-formed humus from that of decomposed biogenic deposits. Pretreatment (by subm., no further treatment in lab.) to obtain humic acid fraction $(0.8 \mathrm{~g})$ from air-dried paleosol as described for GSC1132, above. Sample mixed with dead gas for counting. (One 5-day count in $2-\mathrm{L}$ counter at 1 atm.)

\section{GSC-1053. Clear Lake}

$$
10,400 \pm 200
$$

8450 B.c.

Organic, silty clay from 471 to $476 \mathrm{~cm}$ below mud/water interface in Clear Lake, $5 \mathrm{~km}$ NNW of Tiger Lily, Alberta $\left(54^{\circ} 14^{\prime} \mathrm{N}\right.$ Lat, $114^{\circ}$ $47^{\prime} 30^{\prime \prime} \mathrm{W}$ Long), alt $700 \mathrm{~m}$. Lake occupies kettle hole in end morainal zone. Coll. 1968 by J. Terasmae and R. J. Mott. Comment (R.J.M.): date is minimum for deglaciation and for drainage of small glacial lakes that bordered ice. NaOH-leach omitted from sample pretreatment. Sample mixed with dead gas for counting.

\section{GSC-1019-2. Freeman section, Fort Assiniboine $\quad \mathbf{5 0 , 2 5 0}$ B.C.}

Wood from bed of outwash gravel $>5 \mathrm{~m}$ thick, above till, and overlain, successively, by sand, till, varved sediments, and sand; exposed in cut on $\mathrm{S}$ side Freeman R., $11 \mathrm{~km} \mathrm{WNW} \mathrm{of} \mathrm{Fort} \mathrm{Assiniboine,}$ ca. $7.5 \mathrm{~km}$ upstream from junction of Athabasca R., Alberta (54 $21^{\prime}$ $30^{\prime \prime} \mathrm{N}$ Lat, $114^{\circ} 53^{\prime} 00^{\prime \prime} \mathrm{W}$ Long). Sample from ca. $5 \mathrm{~m}$ above river, $25 \mathrm{~m}$ below surface. Coll. 1968 by D. A. St-Onge. Two determinations:

GSC-1019. (two 1-day counts in 5-L counter) >40,000

GSC-1019-2. (one 3-day count and two 1-day counts in 5 - $\mathrm{L}$ counter at $4 \mathrm{~atm})$

$52,200 \pm 1760$

Comment (W.B., Jr.): if finite date is valid, it may date widespread stratified intertill deposit in area (cf. St-Onge, 1969). Coal fragments, sand, and silt adhered to wood when received. A section was sawed from middle of $0.3 \mathrm{~m}$-long piece, and all outside wood was cut off. Wood may still have been contaminated by this older organic material; cf. GSC-501, >42,500 (R., 1967, v. 9, p. 171) wood in contorted sand below till on Goose R., ca. $120 \mathrm{~km}$ to NW.

\section{Freeman River series}

Wood and fresh-water gastropods (mainly Stagnicola palustris and Fossaria dalli; id. by A. H. Clarke, Jr., Natl. Mus. Nat. Sci., Ottawa), from contorted calcareous sandy silt at $6 \mathrm{~m}$ depth, $\mathrm{N}$ side small creek cutting E bank Freeman R., Alberta (54 $35^{\prime} \mathrm{N}$ Lat, $115^{\circ} 00^{\prime \prime} \mathrm{W}$ Long), alt ca. $745 \mathrm{~m}$. Silt unit, $35 \mathrm{~m}$ long and at least $3 \mathrm{~m}$ thick, is overlain by till-like material. Coll. 1967 by D. A. St-Onge.

\section{GSC-859. Freeman River, wood}

$10,900 \pm 160$ 8950 B.C.

GSC-903. Freeman River, shells $\quad 12,400 \pm 600$

General Comments (D.A.St-O.): dates suggest GSC-859 was contemporary 
with pond; (W.B., Jr.): discrepancy between dates not resolved, but wood is less subject to contamination. Only outermost $10 \%$ of GSC-903 removed due to small sample $(6.5 \mathrm{~g})$. Sample mixed with dead gas for counting. (One 4-day count.)

\section{GSC-861. Greencourt}

$10,200 \pm 170$

8250 B.C.

Gastropods from thin lens of silty sand in thick deposit of lacustrine silty clay, from $1 \mathrm{~m}$ depth, $10.5 \mathrm{~km} \mathrm{E}$ of Greencourt, Alberta $\left(54^{\circ} 00^{\prime} 15^{\prime \prime} \mathrm{N}\right.$ Lat, $115^{\circ} 04^{\prime} \mathrm{W}$ Long), alt ca. $700 \mathrm{~m}$. Contorted sandy silt is part of a thick lacustrine deposit in area of hummocky topography. Coll. 1967 by D. A. St-Onge. Comment (D.A.St-O.): dates phase of Glacial Lake Edmonton (St-Onge, in press). Only outermost $5 \%$ of shell removed.

\section{GSC-1155. Peyto Glacier}

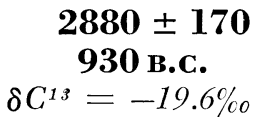

Wood fragment (Picea or Larix, microscopic features like P. engelmanni; id. by R. J. Mott) from lateral moraine $60 \mathrm{~m}$ NE of Inland Waters Branch Glaciology Camp at Peyto Glacier, Alberta $\left(51^{\circ} 41^{\prime} 15^{\prime \prime}\right.$ $\mathrm{N}$ Lat, $116^{\circ} 32^{\prime} 30^{\prime \prime} \mathrm{W}$ Long), alt $2010 \mathrm{~m}$ (ca. $200 \mathrm{~m}$ above present timberline), $40 \mathrm{~m}$ above edge of glacier. Specimen contains 180 counted annual rings plus ca. 15 rings toward pith and ca. 50 rings toward bark which are damaged by decay and cannot be counted with certainty. Curvature of rings indicates that sample is weathered fragment from much larger tree trunk (not krumholtz). Annual rings are very small (mean ring width $0.175 \mathrm{~mm}$ ) but lack width variability required for dendrochronologic cross-dating. Coll. 1968 by H. Smedsrud; subm. by W. Henoch, Inland Waters Branch, Ottawa, and M. L. Parker, now at Univ. of British Columbia, Vancouver. Comment (M.L.P.): date, on 10ring sample ca. 115 rings from outside, indicates time of more favorable climate when timberline was higher than today (cf. dates on wood exposed by glacier retreat in British Columbia, R., 1968, v. 10, p. 226; also dates for California and Nevada, LaMarche and Mooney, 1967). Sample mixed with dead gas for counting.

\section{British Columbia}

\section{Meadow Creek series (III)}

Peat and wood from road cuts near borrow pit on $\mathrm{E}$ side of Meadow Creek, $2.4 \mathrm{~km} \mathrm{~W}$ of Duncan Lake Dam, $9.6 \mathrm{~km} \mathrm{~N}$ of Kootenay Lake, British Columbia $\left(50^{\circ} 15^{\prime} \mathrm{N}\right.$ Lat, $116^{\circ} 59^{\prime} \mathrm{W}$ Long). Road cut exposed till overlying interstratified silt and gravel containing peat beds and wood (Fulton, 1968; R., 1968, v. 10, p. 224-225). Two samples described were from beds interpreted as occupying same stratigraphic position. Coll. 1966 by R. J. Fulton. For other dates in same series see R., 1970, v. 12, p. 70-71. One from each of 2 groups of samples dated in 5-L counter at 4 atm was re-run in 1969 to check reproducibility of results 
obtained in 1967 (GSC-740) and 1968 (GSC-1017), and because the 2 series, though agreeing internally, did not fit as well as hoped.

\section{GSC-740-2. Meadow Creek (I) $\quad 43,000 \pm 600$ \\ Root in situ $265 \mathrm{~cm}$ below top $\mathbf{4 1 , 0 5 0}$ в.c.} (One 1-day and one 3-day count in 5-L counter at $4 \mathrm{~atm}$.)

\section{GSC-1017-2. Meadow Creek (IX)}

$43,600 \pm 700$

41,650 в.c. 1-day counts and one 3 -day coun in silt, $3 \mathrm{~m}$ below contact with till. (Two General Comme 3 -day count in 5-L counter at $4 \mathrm{~atm}$.)

General Comments (R.J.F.): GSC-740-2 agrees with date obtained for this sample in $1967(43,800 \pm 800)$. GSC-1017-2 is significantly older than date obtained for part of same sample in $1968(41,500 \pm 520)$ and fits original stratigraphic interpretation (see comment for GSC-1017, R., 1970, v. 12, p. 70); (W.B., Jr.): discrepancy between GSC-1017 and GSC-1017-2 is unexplained. Rootlet penetration from above was suggested as a possible cause for GSC-1017 being too young, but because GSC-1017-2 fits with other dates, this no longer holds, unless sample was inhomogeneous (e.g,. rootlets having penetrated part used for GSC1017 and not part used for GSC-1017-2). Any sample of peat or other organic debris can easily be "contaminated" in sense that it contains compacted or detrital material of different ages, and, in this age range only $0.1 \%$ contamination by modern carbon would cause an error of ca. $2000 \mathrm{yr}$ (Olsson and Blake, 1962).

\section{GSC-1188. Balfour Creek (II)}

$19,900 \pm 230$

Charcoal scattered through 5 to $10 \mathrm{~cm}$ silt and fine-grained sand, underlying thin volcanic ash bed in large pit on $\mathrm{N}$ side of Columbia R., $8 \mathrm{~km} \mathrm{~W}$ of Castlegar, British Columbia $\left(49^{\circ} 21^{\prime} 00^{\prime \prime} \mathrm{N}\right.$ Lat, $117^{\circ}$ $44^{\prime} 50^{\prime \prime}$ W Long). Coll. 1968 by R. J. Fulton. Comment (R.J.F.): previous sample from same site was dated at 33,000 \pm 280 yr (GSC-1008: R., 1970 , v. 12, p. 70-71). Volcanic ash was not exposed when original sample
was coll. and original site had been destroyed before GSC-1188 was taken. At time of coll. it was thought that GSC-1188 was topographically and stratigraphically lower than GSC-1008. No information is at present available to resolve apparent conflict of dates. (One 3-day count.)

\section{GSC-1119. Rodd Creek}

$9100 \pm 140$

Mucky peat from base 350 to $360 \mathrm{~cm}$ depth, 7150 B.C. alt near headwaters of Rodd alt near headwaters of Rodd Creek, on $\mathrm{E}$ side of Columbia R. valley $17.5 \mathrm{~km} \mathrm{~S}$ of Nakusp, British Columbia $\left(50^{\circ} 05^{\prime} 34^{\prime \prime} \mathrm{N}\right.$ Lat, $117^{\circ} 49^{\prime}$ $14^{\prime \prime}$ W Long). A $10 \mathrm{~cm}$-thick volcanic ash bed occurred at $285 \mathrm{~cm}$ depth. Coll. 1968 with Davis sampler by R. J. Fulton and R. A. Achard. Comment (R.J.F.): date is minimum for deglaciation, but is considerably younger than basal peat sample at same alt ca. $77 \mathrm{~km}$ to $\mathrm{S}$ (GSC-855, 
$10,000 \pm 150:$ R., 1970 , v. 12 , p. 71$)$. NaOH-leach omitted from sample pretreatment. (One 3-day count.)

\section{GSC-1183. Mt. Revelstoke}

Basal peat at 132 to $137 \mathrm{~cm}$ depth, above volcanic ash (Mazama?) overlying bedrock from deposit at $\mathrm{N}$ end of pool near Jades Lakes, Mt. Revelstoke Natl. Park, British Columbia $\left(51^{\circ} 04^{\prime} 25^{\prime \prime} \mathrm{N}\right.$ Lat, $118^{\circ} 04^{\prime}$ $15^{\prime \prime} \mathrm{W}$ Long), alt $1830 \mathrm{~m}$. Pool is one of several in depressions in quartzitic bedrock, but higher water level is due to development of dam-like peat deposits from which sample was taken. Coll. 1967 with split-tube corer by R. D. Muir, Natl. Parks Branch (now with Canadian Wildlife Service, Ottawa). Comment (R.D.M.): date supports field evidence that peat deposit developed in situ over a considerable period; plant growth appears to have been continuous for last $5500 \mathrm{yr}$ (Muir, 1970). NaOHleach omitted from sample pretreatment.

\section{GSC-1306. Revelstoke}

$9490 \pm 160$

Flakes and flat pieces of wood, some charred, in micaceous sandy matrix recovered from a borehole drilled by C.B.A. Engineering Ltd. for British Columbia Hydro and Power Authority, ca. $300 \mathrm{~m}$ downstream from railway and hwy bridge at Revelstoke, British Columbia $\left(51^{\circ} 00^{\prime}\right.$ $\mathrm{N}$ Lat, $118^{\circ} 12^{\prime} \mathrm{W}$ Long). Borehole is on main terrace, alt $455 \mathrm{~m}$, on which city is built, and was $12 \mathrm{~m}$ above Columbia R. before construction of Keenleyside (formerly Arrow) Dam; sample from ca. $29 \mathrm{~m}$ depth, alt $426 \mathrm{~m}$. Borehole penetrated a succession of sand with some laminated silt to total depth $40 \mathrm{~m}$. Comment (H.W.N.): date is maximum for deposition of overlying sand and formation of terrace on which Revelstoke is built. It suggests that level of Arrow Lake (ca. $40 \mathrm{~km} \mathrm{~S}$ ) then was higher than lake level in recent time (419 to $427 \mathrm{~m}$ ). $\mathrm{NaOH}-$ leach omitted from sample pretreatment.

\section{GSC-1258. Canoe River valley}

$21,700 \pm 240$

Wood (coniferous, id. by R. J. Mott) from stratified blue-gray sandy silt overlying glacial gravel grading down into till. Road cut, ca. $25 \mathrm{~m}$ above $\mathrm{E}$ bank of Canoe R., $6.6 \mathrm{~km} \mathrm{~N}$ of confluence with Columbia R., British Columbia (52० $11^{\prime} 40^{\prime \prime} \mathrm{N}$ Lat, $118^{\circ} 27^{\prime} 23^{\prime \prime} \mathrm{W}$ Long), alt $615 \mathrm{~m}$. Coll. 1969 by R. A. Achard. Comment (R.A.A.): wood samples were rounded and worn, implying probable transport from original setting into sandy silt deposited during retreat of last ice. Date agrees with GSC-173, 21,500 \pm 300 , on woody plant detritus coll. $12 \mathrm{~km} \mathrm{~S} \mathrm{(R.,} \mathrm{1965,}$ v. 7, p. 32; Fulton, 1968). Dates indicate that parts of Rocky Mountain Trench were free of ice at end of Olympia Interglaciation (Armstrong et al., 1965), immediately before last major glacial advance. (One 3-day count.) 


\section{GSC-947. Three Valley Lake}

$7640 \pm 150$

Sandy basal peat from bog or

fluence of British Colum British Columbia $\left(50^{\circ} 55^{\prime} \mathrm{N}\right.$ Lat, $118^{\circ} 28^{\prime} \mathrm{W}$ Long). Sample from bottom $10 \mathrm{~cm}$ of bog sec. consisting of ca. $315 \mathrm{~cm}$ of brown sandy peat and partially decomposed sphagnum peat. Peat overlies an undetermined thickness of gray silt and clay. Coll. 1967 by G. W. Smith, Ohio State Univ., Columbus; now at Ohio Univ., Athens, Ohio, with Hiller sampler. Comment (G.W.S.): date, minimum for deglaciation in $\mathrm{W}$ end of Eagle R. valley, is considerably younger than GSC-923, $9280 \pm 160$ (R., 1970, v. 12, p. 72), basal peat in bog near Lusk Lake, ca. $39 \mathrm{~km}$ to SSW. NaOH-leach omitted from sample pretreatment.

\section{GSC-1231. 'Dawson Creek slide' \\ A.D. 1950 \\ $\mathbf{0} \pm 140$}

Wood from broken log among large boulders in center of extensive rock slide (max. est. vol., $25 \times 10^{6} \mathrm{~m}^{3}$ ) on $\mathrm{W}$ slope of Canoe $\mathrm{R}$. valley, opposite mouth of Dawson Creek, British Columbia $\left(52^{\circ} 15^{\prime} \mathrm{N}\right.$ Lat, $118^{\circ}$ 32' W Long), alt ca. 1220 m. Coll. 1969 by R. A. Achard. Comment (R.A.A.): slide is most recent in Canoe R. valley. New growth of trees on lower sides and bottom of slide does not seem older than $100 \mathrm{yr}$; date indicates that slide occurred at earliest ca. $150 \mathrm{yr}$ ago (Achard, 1970). (One 1-day count.)

\section{GSC-946. Trinity Valley}

$15,000 \pm 330$

Basal peaty marl from bog at head of Christian Creek, $19 \mathrm{~km} \mathrm{~N}$ of Lumby, British Columbia $\left(50^{\circ} 25^{\prime} \mathrm{N}\right.$ Lat, $118^{\circ} 54^{\prime} \mathrm{W}$ Long), alt ca. $745 \mathrm{~m}$. Sample from base of marl/peat sequence at $340 \mathrm{~cm}$ depth. Bog sec. overlies undetermined thickness of massive gray lacustrine silt. Coll. 1967 by G. W. Smith with Davis sampler. Comments (G.W.S.): date is minimun for deglaciation of $\mathrm{N}$ uplands of Sugar Lake map-sheet; (R.J.F.): date is 4000 yr older than other bog bottom dates from Interior System (cf. GSC-905, 10,200 \pm 190 and GSC-909, 11,000 $\pm 180:$ R., 1970, v. 12, p. 71-72). According to Mullineaux et al. (1965) Fraser Glaciation ice had not reached its maximum in Puget Lowland 15,000 yr ago; it is unlikely it would have been retreating from interior of British Columbia at this time. Possibly, peaty material dated had picked up carbon from enclosing marly sediments or sample included lignite reworked from local Tertiary sediments. NaOH-leach omitted from sample pretreatment. Sample mixed with dead gas for counting. (One 3-day count.)

\section{Keremeos series}

GSC-1390. Keremeos, charcoal

$$
\begin{aligned}
& 9120 \pm 540 \\
& 7170 \text { B.C. }
\end{aligned}
$$

Bits of charcoal, up to $2 \mathrm{~cm}$ long, mixed with material of buried surface horizon (Ahb), including organic matter of plant origin (humus), 
silt, and sand, from lower portion of downward-pointing, tongue-like horizon at 50 to $70 \mathrm{~cm}$ depth, $2.2 \mathrm{~km} \mathrm{NE}$ of Lakeview $\mathrm{mt}$. peat, in Ashnola R. drainage near Keremeos, British Columbia $\left(49^{\circ} 03^{\prime} 36^{\prime \prime} \mathrm{N}\right.$ Lat, $120^{\circ} 08^{\prime} 28^{\prime \prime} \mathrm{W}$ Long), alt ca. $2480 \mathrm{~m}$ and ca. $300 \mathrm{~m}$ above present tree-line. Coll. 1965 by A. L. van Ryswyk, Canada Dept. of Agr. Res. Sta., Kamloops, B.C., from soil profile pit (Site 37, van Ryswyk, 1969) dug at edge of frost-riven rock ring formation near top edge of a cirque-like slope, on nearly level ground. Comment (A.L.v.R.): date indicates that tree or shrub-like vegetation, much larger than present dwarf willow a few $\mathrm{cm}$ high, grew at site soon after last ice retreat and was subsequently buried by ice wedge and/or solifluction processes. Evidence of both exists adjacent to site. Charcoal bits picked out of sample. NaOH-leach omitted because of small sample size $(4.2 \mathrm{~g})$.

\section{GSC-1249. Keremeos, peat}

\section{A.D. 1950}

$\mathbf{0} \pm \mathbf{1 3 0}$

Dry (in field) brown moss peat $10 \mathrm{~cm}$ thick, on surface in slight hollow and underlain by $10 \mathrm{~cm}$ of transition material and thin angular cobbly, gravelly, coarse sandy loam showing features (gleysolic) of permanent wetness, $2.6 \mathrm{~km}$ NNE of Lakeview mt. peak, in Ashnola R. drainage near Keremeos, British Columbia $\left(49^{\circ} 04^{\prime} 03^{\prime \prime} \mathrm{N}\right.$ Lat, $120^{\circ}$ $19^{\prime} 00^{\prime \prime} \mathrm{W}$ Long), alt ca. $2410 \mathrm{~m}$, ca. $300 \mathrm{~m}$ above present tree-line. Topography was undulating on $12 \%$ overall slope. Coll. 1966 by A. L. van Ryswyk. Comment (A.L.v.R.): date indicates contemporary peat formation. As peat was dry when sampled and showed no signs of living moss at surface, it was hoped deposit indicated a change to dry climate at some time in past. Possibly drainage route of subsurface waters has altered and less water is supplied to site so that peat formation has ceased but gleysolic character is maintained. Sample was ground to pass $2 \mathrm{~mm}$ sieve with no further treatment. $\mathrm{NaOH}-$ leach omitted because of small sample size $(15 \mathrm{~g})$. (One 3-day count.)

\section{GSC-1274. Sukunka River}

$$
\begin{gathered}
2000 \pm 130 \\
50 \text { B.C. }
\end{gathered}
$$

Wood (S Stix sp, id by R. J Mott) from river-cits s of Sukunka R., ca. $14.5 \mathrm{~km} \mathrm{~S}$ of Chetwynd, British Columbia $\left(55^{\circ} 35^{\prime}\right.$ $00^{\prime \prime} \mathrm{N}$ Lat, $121^{\circ} 36^{\prime} 30^{\prime \prime} \mathrm{W}$ Long). Wood from upper part of $2 \mathrm{~m}$ contorted silt and pebbly sand, overlain by ca. $6 \mathrm{~m}$ undisturbed lacustrine silts. Coll. 1969 by N. W. Rutter. Comment (N.W.R.): age is maximum for extensive late postglacial lake in Sukunka $R$. valley. (One 3-day count.)

\section{Cook Street series, Victoria}

Sewer excavation along Cook St., Victoria, British Columbia $\left(48^{\circ}\right.$ $24^{\prime} 45^{\prime \prime} \mathrm{N}$ Lat, $123^{\circ} 21^{\prime} 15^{\prime \prime} \mathrm{W}$ Long), in 1968, exposed what appears to be a continuous succession of sediments from late-glacial marine clay through fresh-water sediments to black organic muck (sapropel). Contact between marine clay and fresh water sediments is ca. $1.2 \mathrm{~m}$ above 
present high tide. Fresh-water deposits above contact show no evidence of subsequent marine transgression. Coll. 1968 with Shelby tube by H. W. Nasmith, Thurber Consultants Ltd., Victoria.

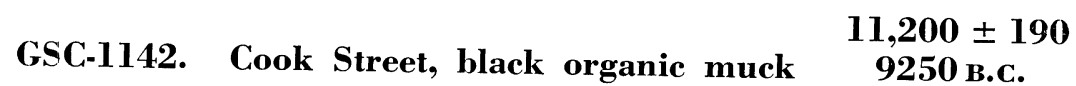 $\delta C^{13}=-24.1 \%$}

$3 \mathrm{~cm}$-long sec. 15 to $18 \mathrm{~cm}$ above GSC-1131, $1 \mathrm{~cm}$ above base of fine-grained black organic muck, above fresh-water shell zone.

\section{$11,500 \pm 160$
GSC-1131. Cook Street, organic lake deposit 9550 B.c. $\delta C^{13}=-21.5 \%$}

$7 \mathrm{~cm}$ thick organic material (incl. Chara sp., seeds of Potamogeton sp., fragments of vascular plants; id. by M. Kuc), enclosing fresh-water shells (GSC-1130), above contact with underlying brown sand and gray
clay. (One 3-day count.)

\section{GSC-1130. Cook Street, fresh-water shells}

$$
\begin{gathered}
11,200 \pm 170 \\
9250 \text { в.c. } \\
\delta C^{13}=+1.0 \% 0
\end{gathered}
$$

Fresh-water shells (mainly Gyraulus parvus and Lymnaea stagnalis, id. by A. H. Clarke, Jr., Natl. Mus. Nat. Sci., Ottawa) within organic material (GSC-1131) above contact with underlying brown sand and gray clay. No correction applied to date as initial $\mathrm{C}^{14}$ content unknown.

\section{GSC-1114. Cook Street, marine shells $\quad 12,100 \pm 160$ \\ Marine shells (Saxich 10,150 B.C.}

Clarine shells (Saxidomus giganteus, an intertidal clam, id. by A. H. Clarke, Jr.) enclosed in gray silty clay from ca. $45 \mathrm{~cm}$ below contact with overlying fresh-water shells and organic material.

General Comment (H.W.N.): dates on marine shells in Greater Victoria area range in age and alt from 12,660 \pm 160 at $27 \mathrm{~m}$ (GSG-246: R., 1965 , v. 7, p. 36) to $12,100 \pm 160$ at $+2.2 \mathrm{~m}$ geodetic (GSC-1114) and seem to mark rapid regression of sea level from post-glacial maximum at +68.5 to $84 \mathrm{~m}$ (Mathews et al., 1970). Sea level fell to present shoreline between 12,100 and 11,200 yr B.P. (dates bracket time at which postglacial marine submergence ended at $S$ tip Vancouver I.). Other evidence indicates that sea level fell below present shoreline for several thousand yr. Overlap of dates between fresh-water deposits and organic muck suggests fresh-water pond phase was very brief, as also indicated by fresh water shell assemblage, representative of eutrophic, well-vegetated habitat (A. H. Clarke, Jr., 1970, written commun.). NaOH-leach omitted from pretreatment of GSC-1131 and GSC-1142. Due to small size of GSC-1130 no shell removed by leaching.

\section{GSC-1385. Empress Hotel, Victoria}

$4000 \pm 200$

Wood (Picea sp., prob. P. sitchensis, id. by R. J. Mott) from bore- 
hole drilled adjacent to $\mathrm{S}$ wing of Empress Hotel, Victoria, British Columbia $\left(48^{\circ} 25^{\prime} 15^{\prime \prime} \mathrm{N}\right.$ Lat, $123^{\circ} 22^{\prime} 00^{\prime \prime} \mathrm{W}$ Long). Wood at $9.3 \mathrm{~m}$ depth (surface alt ca. $5.4 \mathrm{~m}$, geodetic datum) is contained in silty clay, a recent estuarine deposit in shallow arm of Victoria Harbour. Mud is covered by $8 \mathrm{~m}$ dredged fill, placed 1904, and overlies late-glacial marine clay with a weathered crust (Crawford and Sutherland, 1971). Coll. 1969 with Shelby tube and subm. by C. B. Crawford, NRC, and H. W. Nasmith. Comment (H.W.N.): following deposition of marine clay ca. 12,000 to 13,000 yr B.P., relative sea level fell below present sea level and clay was exposed on bottom of Victoria Harbour (cf. Mathews et al., 1970). A crust formed on clay during subaerial weathering. Sea level rise to present position flooded crust, and date is minimum for this event. (One 3-day count.)

\section{Ospika River series}

Wood and peat from $2.5 \mathrm{~m}$ depth in river-cut terrace on $\mathrm{W}$ bank of Ospika R., British Columbia $\left(56^{\circ} 10^{\prime} \mathrm{N}\right.$ Lat, $124^{\circ} 07^{\prime} \mathrm{W}$ Long). Sample from peat at base of marl underlain by sandy silt layer and gravels. These, in turn, are underlain by proglacial lacustrine silt (not observed at this site.) Coll. 1968 by N. W. Rutter.

GSC-1069. Ospika River, wood

(One 3-day count.)

GSC-1161. Ospika River, peat

$7480 \pm 150$

5530 B.c.

Peat, composed mainly of calciphilous mosses (Scorpidium scorpioides dominates, Calliergon trifarium also present; both id. by $\mathrm{M}$. Kuc), from marl in same zone as GSC-1069 but $1 \mathrm{~m}$ distant horizontally General Comment (N.W.R.): dates are minimum for underlying proglacial lake deposits and provide close check on different organic materials in same deposit. NaOH-leach omitted from pretreatment of GSC-1161.

\section{Finlay River series}

\section{$25,940 \pm 380$}

River, $\mathbf{E}$ bank,

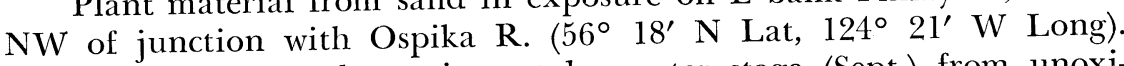
Sample coll. $0.6 \mathrm{~m}$ above river at low-water stage (Sept.) from unoxidized lower sand in ca. $4.5 \mathrm{~m}$ thick unit (base not seen) of sand grading upward to silty sand and silt, in turn overlain by $<2 \mathrm{~m}$ boulders and gravel containing till-like lenses, capped by lake silt. Coll. 1965 by J. G. Fyles. Comment (J.G.F.): gravel and till-like material inferred to represent glaciation. Finite date is only one available in region (Rutter, 1967); it is farthest $\mathrm{N}$ (by ca. $565 \mathrm{~km}$ ) occurrence of numerous sub-till dates in this range in interior British Columbia (cf. GSC-1258, 21,700 \pm 240 , 
this list). Other samples to $\mathrm{N}$ (ca. $110 \mathrm{~km}$ ) in series along Finlay $\mathrm{R}$. are all infinite. NaOH-leach omitted from sample pretreatment.

GSC-837. Finlay River, W bank, wood

Wood fragments from ca. $44 \mathrm{~m}$ depth on W bank Finlay R. (57 $11^{\prime} \mathrm{N}$ Lat, $125^{\circ} 20^{\prime} \mathrm{W}$ Long), scattered in a sand lens within oxidized sand and gravel, overlain, unconformably, by outwash below 2 tills. Coll. 1967 by N. W. Rutter. Comment (N.W.R.): assuming wood is same age as enclosing material, date is minimum for oxidized sand and gravel that may represent interglacial deposit. (One 4-day count).

GSC-841. Finlay River, E bank, "peat-like"

Peat-like material from $>20 \mathrm{~m}$ depth on E bank Finlay R. (57 $18^{\prime} \mathrm{N}$ Lat, $125^{\circ} 27^{\prime} \mathrm{W}$ Long), from gravel within oxidized sand and gravel, overlain unconformably by outwash underlying till and/or icecontact gravel. Coll. 1967 by N. W. Rutter. Comment (N.W.R.): oxidized sand and gravel are probably correlative with similar unit containing GSC-837 (above).

GSC-1057. Finlay River, E bank, wood

Wood fragments from ca. $10 \mathrm{~m}$ depth on E bank Finlay R. (57 $18^{\prime} \mathrm{N}$ Lat, $125^{\circ} 27^{\prime} \mathrm{W}$ Long), from sand wedge within a unit of oxidized sand and gravel overlain unconformably by postglacial gravel. Coll. 1968 by N. W. Rutter. Comment (N.W.R.): enclosing material believed correlative with oxidized sand and gravel in which GSC-837 and GSC-841 were coll. Sample mixed with dead gas for counting.

GSC-927. Finlay River, E bank, charcoal (I) $\begin{array}{r}520 \\ \text { A.D. } 1430\end{array}$

$$
520 \pm 140
$$

$\delta C^{13}=-24.5 \%$ o

Wood, charred wood, and charcoal from ca. $5.5 \mathrm{~m}$ below surface of river cut on E side Finlay R. ca. $3 \mathrm{~km} \mathrm{NW}$ of Del Creek $\left(57^{\circ} 11^{\prime}\right.$ $\mathrm{N}$ Lat, $125^{\circ} 18^{\prime} \mathrm{W}$ Long), from oxidized layer of buried sandy soil overlain by windblown sand. Soil underlain by $>75 \mathrm{~m}$ of several glacial units. Coll. 1967 by N. W. Rutter. Comment (N.W.R.): date does not give maximum age for deposition of sand overlying soil (cf. GSC-944, below). Although sample was hand-picked and all visible rootlets were removed, some rootlets probably remained in wood pieces. $\mathrm{NaOH}$-leach omitted from sample pretreatment.

\section{GSC-944. Finlay River, E bank, charcoal (II)}

$$
\begin{array}{r}
840 \pm 140 \\
\text { A.D. } 1110 \\
\delta C^{13}=-25.8 \% \text { o }
\end{array}
$$

Same location and sample material as GSC-927. This part of sample underwent nitration and acetone leaching as described by Haynes (1966). Comments (N.W.R.): date is probably more accurate than GSC-927; (W.B., Jr. and J.A.L.): as indicated in Table 3, (R., 1970, v. 12, p. 474), wood and charred wood predominated over charcoal in sample. Weight of GSC-927 decreased only from $9.7 \mathrm{~g}$ to $7.9 \mathrm{~g}$ with acid treatment, but 
using Haynes' method, GSC-944 decreased in weight from ca. $20 \mathrm{~g}$ to $4.5 \mathrm{~g}$, hence it was mixed with dead gas for counting. However, discrepancy between dates probably cannot be explained solely by contamination by modern rootlets. A $40 \%$ decrease in age, in this range, would require 20 to $50 \%$ contamination by modern material.

\section{Tiedemann Glacier series}

Peat and organic muck from 2 bogs on $\mathrm{N}$ side Tiedemann Glacier, $24 \mathrm{~km} \mathrm{E}$ of Mt. Waddington, British Columbia $\left(51^{\circ} 21^{\prime} 00^{\prime \prime} \mathrm{N}\right.$ Lat, $124^{\circ} 56^{\prime} 30^{\prime \prime}$ W Long). Coll. 1967 with Davis sampler by R. J. Fulton.

\section{GSC-948. Moraine bog (I)}

$2250 \pm 130$

300 B.C. count.)

Peat overlying $10 \mathrm{~cm}$ silt bed at 210 to $217 \mathrm{~cm}$ depth. (One 3-day

GSC-938. Moraine bog (II)

$2940 \pm 130$

990 B.C.

Peat from ca. $227 \mathrm{~cm}$ depth, underlying $10 \mathrm{~cm}$ silt bed.

$$
\delta C^{13}=-26.8 \%
$$

$9510 \pm 160$

7560 B.C.

GSC-939. Moraine bog (III) deposit.

Basal peat, 275 to $285 \mathrm{~cm}$ depth, from $285 \mathrm{~cm}$-thick sphagnum peat

\section{GSC-977. Inner moraine bog}

$1270 \pm 140$ A.D. 680

$\delta C^{13}=-26.3 \%$

Fibrous organic muck from base of $88 \mathrm{~cm}$-thick bog deposit.

General Comment (R.J.F.): moraine bog lies immediately outside a moraine of Tiedemann Glacier postdating the Fraser Glaciation; a 10 $\mathrm{cm}$-thick silt bed extending throughout bog is thought to have been deposited while ice stood against post-Fraser moraine. GSC-948 and GSC938 bracket time of advance, GSC-939 is minimum for retreat of Fraser ice from area. Inner moraine bog lies in area of ridges inside oldest post-Fraser moraine; GSC-977 is minimum for retreat of Tiedemann Glacier from area between its post-Fraser maximum and its present position. $\mathrm{NaOH}$-leach omitted from pretreatment of all samples. GSC939 and GSC-977 mixed with dead gas for counting.

\section{GSC-1124. Aiyansh lava flow \\ A.D. 1700 \\ $\delta C^{13}=-23.5 \%$}

$250 \pm 130$

Cottonwood (Populus sp., id. by R. J. Mott) from standing log encased in lava at NE end of flow beside Nass R., British Columbia $\left(55^{\circ} 13^{\prime} \mathrm{N}\right.$ Lat, $129^{\circ} 08^{\prime} \mathrm{W}$ Long). Coll. 1968 by P. Hughan, Aiyansh; subm. by Sutherland Brown, B.C. Dept. Mines and Petroleum Resources, Victoria, and J. G. Souther. Comments (A.S.B.): data confirm age of 
this young basalt flow as suggested by legend and reported age of involuted trees (cf. Sutherland Brown, 1969 and Souther, 1970, where uncorrected date for GSC-1124, $220 \pm 130$, is reported). (One 3-day count.)

GSC-771. Mt. Edziza (II)

$>43,000$

Charred wood, compressed but apparently coniferous (R. J. Mott, pers. commun.), from layer of unconsolidated crystal tuff at base of 240 m-sec. of basalt, Mt. Edziza, British Columbia $\left(57^{\circ} 41^{\prime} \mathrm{N}\right.$ Lat, $130^{\circ} 47^{\prime}$ W Long), alt ca. $1315 \mathrm{~m}$. Logs up to $25 \mathrm{~cm}$ diam. appear to have been killed by and preserved in ash, undisturbed by subsequent erosion. Enclosing tuff is underlain by pre-volcanic erosion surface and overlain by earliest basalt flow from Mt. Edziza. Comment (J.G.S.): date is minimum for Mt. Edziza volcanic pile (cf. Souther, 1970 and GSC-566, $1340 \pm 130$, R., 1967, v. 9, p. 174). (One 4-day count.)

\section{GSC-242. Cape Ball, Queen Charlotte Islands}

at Bedford Inst. at Bedford Inst., Dartmouth, Nova Scotia), from shore cliff $460 \mathrm{~m} \mathrm{~N}$ of mouth of Cape Ball R., E coast of Graham I., Queen Charlotte Is., British Columbia (53 $41^{\prime} 30^{\prime \prime} \mathrm{N}$ Lat, $131^{\circ} 53^{\prime} 10^{\prime \prime} \mathrm{W}$ Long), alt $3 \mathrm{~m}$ above present extreme high tide. Shells in situ at top of silt beneath ca. $0.6 \mathrm{~m}$ gravel and sand of former estuary flat. Coll. 1962 by A. Sutherland Brown. Comment (A.S.B.): dates limit of postglacial marine submergence, alt ca. $6 \mathrm{~m}$, on $\mathrm{E}$ coast of Queen Charlotte Is. Complete fauna at site indicated shallow marine conditions with water temperature similar to today's (F. J. E. Wagner, written commun.). This contrasts with GSC-292 on W coast (cf. Sutherland Brown, 1968).

\section{GSC-292 Tasu Sound, Queen Charlotte Istands}

Shell Islands 6110 B.c.

Shell (Ostrea lurida [Carpenter], id. by. F. J. E. Wagner) from $\mathrm{N}$ bank of creek flowing into, and ca. $0.4 \mathrm{~km}$ from, $\mathrm{N}$ end of Barrier Bay, Tasu Sound, Moresby I., Queen Charlotte Is., British Columbia (52 $47.5^{\prime} \mathrm{N}$ Lat, $131^{\circ} 58^{\prime} \mathrm{W}$ Long), est. alt $3.5 \mathrm{~m}$ above present mean high sea level. Coll. 1962 by A. Sutherland Brown. Comment (A.S.B.): dates postglacial limit of marine submergence on SW coast of Queen Charlotte Is. and indicates uplift of same order as GSC-242 from Cape Ball (above). Fauna at site indicated water temperature warmer than at present and comparable to that of Tillamook Bay, Oregon (F. J. E. Wagner, written commun.), in contrast with GSC-242 on E coast. (One 3-day count.)

1. Yukon

C. Northern Canada, Mainland

\section{GSC-1172. Tombstone Range}

$9690 \pm 200$

7740 B.C.

$\delta C^{13}=-22.7 \%$

Organic silt and twigs from 498 to $508 \mathrm{~cm}$ depth in permanently frozen bog sediments in tributary valley to North Klondike R., Tomb- 
stone Range, Ogilvie Mts., Yukon (64 $27^{\prime} \mathrm{N}$ Lat, $138^{\circ} 27^{\prime} \mathrm{W}$ Long), alt between 1370 and $1525 \mathrm{~m}$. Boring on palsa mound from ca. 1.5 $\mathrm{m}$ above surrounding surface to $710 \mathrm{~cm}$ depth. No core recovered from solid ice at 508 to ca. $509 \mathrm{~cm}$ depth or from unfrozen sediments below. Site is inside local limit of widely recognized McConnell Glaciation of central Yukon (Bostock, 1966; Vernon and Hughes, 1966; Hughes et al., 1969), and beyond limit of recent cirque moraines. Coll. 1968 by J. T. Gray, McGill Univ., Montreal. Comment (J.T.G.): date is minimum for retreat of last valley glacier from this upper North Klondike tributary to cirque zone above. Date confirms field evidence that no readvance over site occurred since McConnell Glaciation (cf. GSC-470, 11,250 \pm 160 , ca. 16 $\mathrm{km}$ to NE; R., 1968, v. 10, p. 231). NaOH-leach omitted from sample pretreatment. Sample mixed with dead gas for counting.

\section{Antifreeze Pond series}

Gyttja, mossy peat, and organic silt in cores retrieved from small lake by Livingstone sampler and bordering bog by Sipre corer; $300 \mathrm{~m}$

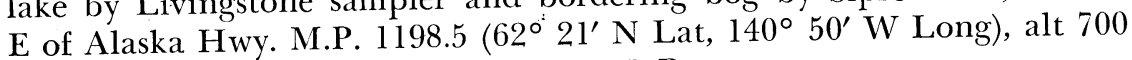
m. Coll. 1965 (GSC-496) and 1968 by V. N. Rampton.

GSC-496. Antifreeze Pond, $645 \mathrm{~cm}$

Organic silt from base of $645 \mathrm{~cm}$ peat and silt sequence in bog.

GSC-1230. Antifreeze Pond, 622 to $640 \mathrm{~cm} \quad \begin{array}{ll}29,700 \pm 7 & 27,750 \text { B.c. }\end{array}$ Organic silt from 622 to $640 \mathrm{~cm}$ interval of cores from lake.

GSC-1198. Antifreeze Pond, 537 to $552 \mathrm{~cm} \quad 25,150$ B.c.

Organic silt from 537 to $552 \mathrm{~cm}$ interval of cores from lake.

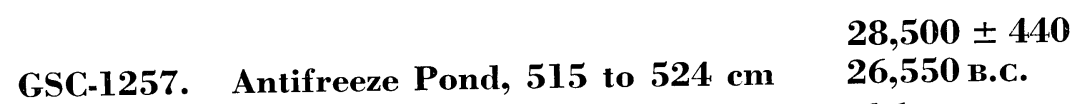

Organic silt from 515 to $524 \mathrm{~cm}$ interval of core from lake.

$$
\begin{array}{ll} 
& \\
\text { GSC-1048. Antifreeze Pond, } 512 \text { to } 532 \mathrm{~cm} & \begin{array}{l}
31,500 \pm 700 \\
29,550
\end{array} . \mathrm{B.c}
\end{array}
$$

Organic silt from 512 to $532 \mathrm{~cm}$ interval of core from lake.

GSC-1110. Antifreeze Pond, 398 to $403 \mathrm{~cm} \quad \begin{array}{ll}13,500 & 11,550 \text { B.c. }\end{array}$

Organic silt from 398 to $403 \mathrm{~cm}$ interval of core from lake.

$\begin{array}{lll} & & 9980 \pm 150 \\ \text { GSC-1042. Antifreeze Pond, } 317 \text { to } 320 \mathrm{~cm} & \mathbf{8 0 3 0} \text { B.c. } \\ \text { Gytjja from } 317 \text { to } 320 \mathrm{~cm} \text { interval of core from lake. }\end{array}$




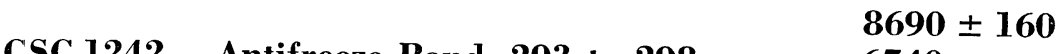 6740 B.C. \\ $\delta C^{13}=-26.5 \%$}

Gyttja and mossy peat (Calliergon trifarium, Drepanocladus exannulatus, and Scorpidium scorpioides; id. by M. Kuc) from 293 to 298 $\mathrm{cm}$ interval of core from lake. Uncorr. date; $8710 \pm 160$, used in Rampton $(1971 b)$.

\section{GSC-1040. Antifreeze Pond, 250 to $255 \mathrm{~cm}$}

$5690 \pm 140$

Gyttja from 250 to $255 \mathrm{~cm}$ interval of core from lake.

General Comment (V.N.R.): GSC-496 confirms that drift plain upon which Antifreeze Pond lies is result of pre-late Wisconsin glaciation (cf. Rampton, 1969 and GSC-959; >38,000, R., 1970, v. 12, p. 80). Remaining dates relate to late Quaternary vegetational history of region as reconstructed from pollen assemblages (cf. Rampton, 1969, 1971b). Pollen diagram suggests fell-field or sedge-moss tundra, followed by shrub tundra, was present between ca. 31,000 and 27,000 в.P. (GSC-1230, -1198, -1257 , and -1048). Sedge-moss tundra was present until ca. 10,000 в.P. (GSC-1042); pollen percentage of aquatics rose at 13,500 B.P. (GSC-1110). Shrub tundra was present between ca. 10,000 and 8700 B.P. (GSC-1242) when it was replaced by spruce woodland, which was replaced by spruce forest at ca. 5700 B.P. (GSC-1040). Organic silt from pollen-analyzed core was supplemented with material from nearby core to provide enough material for GSC-1230 and GSC-1198. GSC-1257 (from supplemental core) was run as a check on GSC-1048 (from analyzed core). Anomalous dates from below $510 \mathrm{~cm}$ interval of cores are believed to result from redeposition of materials via slopewash or thermokarst erosion (cf. Rampton, 1971b). NaOH-leach omitted from pretreatment of all samples except GSC-1230 and GSC-1257, both of which had cold NaOH-leach. GSC-1230 and -1110 mixed with dead gas for counting. GSC-496, -1230, and -1042, each based on one 4-day count; GSC-1257 based on one 3-day count.

\section{GSC.1407. Little Scottie Creek}

$$
\begin{aligned}
& 12,000 \pm 160 \\
& 10,050 \text { в.с. }
\end{aligned}
$$

Peat, ca. 75\% undeterminable vascular plant remains, with (Drepanocladus fluitans, Amblystegium riparium, and Brachyteciacae cf. Eurhynchium sp.; id. by M. Kuc), 8.5 to $8.7 \mathrm{~m}$ depth, retrieved by Winkie diamond drill from frozen sediment adjacent to Alaska Hwy. M.P. 1217.5 in valley of Little Scottie Creek, Yukon $\left(62^{\circ} 34^{\prime} \mathrm{N}\right.$ Lat, $140^{\circ} 57.5^{\prime} \mathrm{W}$ Long), alt $575 \mathrm{~m}$. Sample overlain by $7.8 \mathrm{~m}$ gyttja and organic silt under $0.7 \mathrm{~m}$ surface peat. Coll. 1966 by V. N. Rampton. Comment (V.N.R.): although valley is underlain by early Wisconsin outwash (Hughes et al., 1969) date indicates much in-filling occurred in late or post-Wisconsin time. NaOH-leach omitted from sample pretreatment. (One 3-day count.) 


\section{GSC-506. Difficult Creek}

6910 B.C.

Wood (Salix sp., id. by R. J. Mott) from base of $0.6 \mathrm{~m}$ thick peat in old exposure (ground ice slump) on small lake $1.6 \mathrm{~km} \mathrm{~W}$ of head of Difficult Creek, $2.8 \mathrm{~km}$ E of Kugaryuk Creek, Yukon $\left(69^{\circ} 26^{\prime} \mathrm{N}\right.$ Lat, $139^{\circ} 23^{\prime}$ W Long), alt ca. $30 \mathrm{~m}$, ca. $8.8 \mathrm{~km}$ SSW of Arctic coast. Coll. 1965 by J. G. Fyles. Comment (J.G.F.): date is minimum for mud-flow debris. (One 4-day count.)

\section{Northwest Territories}

\section{Northwest Garry Island series}

Peat and wood from surface blanket of peat up to $1.7 \mathrm{~m}$ thick, and from underlying lacustrine sediments ca. $3 \mathrm{~m}$ thick, in coastal exposures on NW Garry I., N.W.T. (69 $39^{\prime} 05^{\prime \prime} \mathrm{N}$ Lat, $135^{\circ} 47^{\prime} 25^{\prime \prime} \mathrm{W}$ Long). Deposits occupy small depressions. Peat surface has high-centered polygons. GSG-513 and -517 coll. 1964 by D. E. Kerfoot, Univ. of British Columbia, Vancouver; now at Brock Univ., St. Catharines, Ontario. GSC-516 and -575 coll. 1965 by D. E. Kerfoot, J. R. Mackay, Univ. of British Columbia, Vancouver, and J. G. Fyles.

\section{GSC-513. Garry Island, peat, $1.5 \mathrm{~m}$}

Peat from $1.5 \mathrm{~m}$ depth in $1.7 \mathrm{~m}$-thick peat sec., top at alt $4.9 \mathrm{~m}$. Sample level, alt $3.4 \mathrm{~m}$, just below change in pollen assemblage suggestive of Hypsithermal Interval (J. C. Ritchie, Scarborough College, West Hill, Ontario, pers. commun.). Comment (D.E.K.): polygons show no sign of burial, hence not inundated by sea in last $4000 \mathrm{yr}$ (Kerfoot, 1969). NaOH-leach omitted from sample pretreatment.

\section{GSC-517. Garry Island, peat, $1.1 \mathrm{~m}$}

$4120 \pm 130$

Peat from $1.1 \mathrm{~m}$ depth below surface, same site as for GSC-513. Sample, alt $3.8 \mathrm{~m}$, from just above change in pollen sequence which may represent Hypsithermal Interval. Comment (J.G.F.): NaOH-leach omitted from sample pretreatment.

\section{GSC-516. Garry Island, peat, $9.4 \mathrm{~m}$}

$$
10,330 \pm 150
$$

Peat from $10 \mathrm{~cm}$-thick bed exposed in cliff sec., top alt $13 \mathrm{~m}$, ca. $0.5 \mathrm{~km}$ along shore from GSC-513 and -517 . Peat, at alt $9.4 \mathrm{~m}$, overlies gravel above stony clay and is overlain, in succession, by $1.2 \mathrm{~m}$ marl and silt, 1.5 to $1.8 \mathrm{~m}$ gravel (pebble beach), $0.6 \mathrm{~m}$ peat, plus some soliflucted material (cf. Kerfoot, 1969, fig. 6). Comment (W.B., Jr.): peat is younger than wood from nearby higher-level peat and lacustrine silt deposits on Garry I.: S-278, 11,300 \pm 190; S-277, 11,700 \pm 250; R., 1968, v. 10 , p. 371 . NaOH-leach omitted from sample pretreatment. (One 4day count.) 
GSC-575. Garry Island, twigs, $10.7 \mathrm{~m}$

Iron-stained twigs and wood fragments from base of gravel, alt 10.7 $\mathrm{m}$, over marl in same sec. as GSC-516. Comment (W.B., Jr.): date, with GSC-516, at base of marl and silt unit, indicates time that lacustrine phase existed at site. (One 3-day count).

\section{GSC-562. Northern Garry Island}

Marine pelecypod shells (Astarte borealis, A. montagui var. warhami, Mya truncata; id. by F. J. E. Wagner, Bedford Inst., Dartmouth, N.S.) from top part of sand deposit, 7.5 to $9 \mathrm{~m}$ thick, exposed in cliffed headland on N coast Garry I., N.W.T. (69 $39^{\prime}$ N Lat, $135^{\circ} 40^{\prime} \mathrm{W}$ Long). Coll. 1965 by D. E. Kerfoot. Comments (D.E.K. and J.G. Fyles): shells well preserved with periostracum intact, not believed reworked despite absence of hinged specimens. Enclosing sands form marine terrace representing relative sea level 9 to $15 \mathrm{~m}$ above present, following withdrawal of last glacier to reach outer Mackenzie Delta area. GSC-690 (>37,000, this list) dates shells from terrace at same level $16 \mathrm{~km}$ to SE; (W.B., Jr.): due to computer error, date lst reported as $>42,600$; cf. Kerfoot (1969). Sample mixed with dead gas for counting. (One 3-day count).

\section{GSC-690. $\mathrm{S}$ of Kendall Island}

Whole shells and fragments (Astarte borealis) with waterworn wood fragments, from sand and gravel 6 to $7.5 \mathrm{~m}$ above lake, alt ca. sea level, in terrace deposit on unnamed island $16 \mathrm{~km} \mathrm{~S}$ of Kendall I., N.W.T. $\left(69^{\circ}\right.$ $21^{\prime} \mathrm{N}$ Lat, $135^{\circ} 22^{\prime} \mathrm{W}$ Long). Terrace, surface alt ca. $9 \mathrm{~m}$, is part of extensive terrace, probably estuarine, along $\mathrm{W}$ side Richards $\mathrm{I}$. and at same height as equivalent terrace on NE side Garry I. (cf. GSC-562, $>35,000$, this list). Coll. 1966 by J. G. Fyles. Comment (J.G.F.): shells probably not reworked, as they are fresh-appearing with periostracum intact on many, although hinged specimens not found. Assoc. wood probably reworked. Terrace interpreted as representing former sea level ca. $9 \mathrm{~m}$ higher (relative to land) than present following withdrawal of last glacier ice to reach outer Mackenzie Delta area (cf. Fyles, 1967). Due to computer error date 1st given as $>42,600$. (One 3-day count.)

\section{GSC-549. Richards Island}

Wood (Picea sp.; id. by R. J. Mott) from 143 (?) to 152 (?) m below surface in B.A.-Shell-Imperial Reindeer D-27 oil well ca. $12 \mathrm{~km}$ NNE from S tip of Richards I., $1.6 \mathrm{~km} \mathrm{NW}$ of East Channel, Mackenzie R., N.W.T. $\left(69^{\circ} 06^{\prime} 05^{\prime \prime} \mathrm{N}\right.$ Lat, $134^{\circ} 36^{\prime} 54^{\prime \prime} \mathrm{W}$ Long). At surface, gravel (esker?) appears to overlie interglacial sand. Coll. 1965 by J. H. Manning, British Am. Oil Ltd., Edmonton; subm. by J. G. Fyles. Comment (J.G.F.): date suggests subsurface gravel at $\mathrm{S}$ end Richards I. are $>40,000$ yr old. (One 3-day count.) 


\section{GSC-1214. Peninsula Point}

Peat, near base of $1.5 \mathrm{~m}$-thick mud flow colluvium overlying sand, underlying $0.6 \mathrm{~m}$ lacustrine silt in wave-dissected pingo at Peninsula Point, ca. $7.6 \mathrm{~km} \mathrm{SW}$ of Tuktoyaktuk, N.W.T. (69 $24.5^{\prime} \mathrm{N}$ Lat, $133^{\circ}$ 09' W Long). Coll. 1966 by J. G. Fyles; subm. by V. N. Rampton. Comment (V.N.R.): dates local melting of permafrost before deposition of mud-flow debris and start of lake phase. $\mathrm{NaOH}$-leach omitted from sample pretreatment. Sample mixed with dead gas for counting.

\section{GSC-1050. Castle Bluff}
$4390 \pm 130$
2440 B.C.
$\delta C^{13}=-23.4 \%$ o

Wood (Picea sp. or Larix sp..; id. by R. J. Mott) from near base of $3 \mathrm{~m}$ colluvium in $15 \mathrm{~m}$-high sea-cliff exposure of drained thaw pond

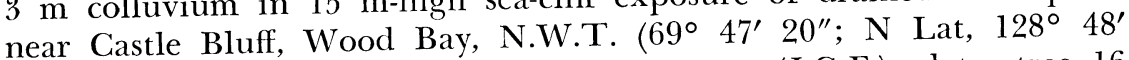
W Long). Coll. 1966 by J. G. Fyles. Comment (J.G.F.): dates tree 16 $\mathrm{km}$ beyond present $\mathrm{N}$ limit of trees. (One 4-day count.)

\section{Cape Bathurst series}

Wood and shells from ca. $3 \mathrm{~m}$-thick marine clay unit underlying ca. $1.5 \mathrm{~m}$ silty sand and up to $2.5 \mathrm{~m}$ surface peat in shore bluff ca. $5 \mathrm{~m}$ high $11 \mathrm{~km} \mathrm{SE}$ of Cape Bathurst, N.W.T. $\left(70^{\circ} 31^{\prime} \mathrm{N}\right.$ Lat, $127^{\circ} 48^{\prime}$ W Long). Coll. 1965 by J. G. Fyles.

GSC-478. Cape Bathurst (I)

Shells (Yoldia arctica). Because of small sample $(8.0 \mathrm{~g})$, HCl-leach omitted from pretreatment. Sample mixed with dead gas for counting. (One 3-day count.)

GSC-545. Cape Bathurst (II)

Wood (Picea or Larix, prob. Picea sp.; id. by R. J. Mott) from alt ca. $1.2 \mathrm{~m}$ in marine clay. (One 5 -day count.)

General Comment (J.G.F.): marine clay exposed above sea level throughout much of unglaciated Cape Bathurst-Baillie I. region (Fyles, 1966; Rampton, 1971a). Assuming wood is not reworked, GSC-545 indicates clays were deposited $>41,000 \mathrm{yr}$ ago.

\section{Horton River series}

GSC-1100. Horton River

Peat beneath ca. $12 \mathrm{~m}$ of till and overlying 2 till units ca. $20 \mathrm{~m}$ thick, exposed in $45 \mathrm{~m}$ bank along $\mathrm{W}$ tributary of Horton R. $\left(69^{\circ} 13^{\prime}\right.$ N Lat, $127^{\circ} 03^{\prime}$ W Long), alt ca. $205 \mathrm{~m}$. Coll. 1968 by R. W. Klassen. Comment (R.W.K.): date records non-glacial interval of interstadial or interglacial rank preceding at least last glaciation of Smoking Hills 
Upland; an early or pre-Wisconsin age for lowest till is suggested. NaOHleach omitted from sample pretreatment. (One 3-day count.)

GSC-576. Horton River

Wood (Picea or Larix sp., id. by R. J. Mott) assoc. with peat within interbedded, cross-laminated sand and silt, beneath ca. $18 \mathrm{~m}$ clay(?) exposed along $\mathrm{W}$ tributary Horton R. (69 $69^{\circ} 12^{\prime} \mathrm{N}$ Lat, $127^{\circ} 05^{\prime} \mathrm{W}$ Long), alt ca. $205 \mathrm{~m}$. Coll. 1965 by D. Waylett, Imperial Oil, Edmonton; subm. by J. G. Fyles. Comment (R.W.K.): wood appears to be from same unit as GSC-1100, ca. $1.6 \mathrm{~km}$ to E. Overlying 'clay' probably includes at least one till, suggesting unit records a non-glacial interval of interstadial or interglacial rank (Fulton and Klassen, 1969).

\section{GSC.1099. Kelly Lake}

$8880 \pm 150$

6930 B.c.

Wood in peat from surface of lake clay and silt $8 \mathrm{~km}$ SW of Kelly Lake, $24 \mathrm{~km} \mathrm{~N}$ of Norman Wells, N.W.T. $\left(65^{\circ} 29^{\prime} \mathrm{N}\right.$ Lat, $126^{\circ} 34^{\prime} \mathrm{W}$ Long), at $1 \mathrm{~m}$ depth, overlain by marl and clay, exposed by landslide. Coll. 1968 by R. J. Fulton. Comment (R.J.F.): wood and peat appear to have accumulated in a thermokarst lake basin formed in glacial-lake silt. Date is minimum for deglaciation, for draining of a glacial lake, and for penetration of glacial lake sediments by permafrost.

\section{GSC-1251. Paulatuk}

$$
\begin{aligned}
& 1030 \pm 140 \\
& \text { A.D. } 920 \\
& \delta C^{13}=-26.3 \% 0
\end{aligned}
$$

Peat from windblown sand at S side of "water lake" at Paulatuk, N.W.T. ( $69^{\circ} 20^{\prime} \mathrm{N}$ Lat, $124^{\circ} 06^{\prime} \mathrm{W}$ Long), $1.2 \mathrm{~m}$ below surface of hillslope formed by sand transported by strong N-blowing winter katabatic winds (Mackay, 1958). Upper slopes have excellent ventifacts. Coll. 1968 by J. R. Mackay. Comment (J.R.M.): date helps establish rate of deflation and abrasion by gravity winds. NaOH-leach omitted from sample pretreatment. Sample mixed with dead gas for counting. (One 3day count.)

\section{GSC-1139. Erly Lake}

$$
10,800 \pm 150
$$

Peaty moss (Drepanocladus exannulatus, Calliergon sarmentosum, and Scorpidium scorpioides; id. by M. Kuc) enclosed in sandy silt from top of $20 \mathrm{~m}$ high pingo $21 \mathrm{~km} \mathrm{~W}$ of Erly Lake, N.W.T. $\left(68^{\circ} 14^{\prime} \mathrm{N}\right.$ Lat, $12^{\circ} 38^{\prime} \mathrm{W}$ Long). Organic material from $2 \mathrm{~m}$ thick lake sediment overlying gravelly till. M. Kuc reports (pers. commun.) that bryophytes are assemblage of permanently submerged species. Coll. 1968 by R. J. Fulton. Comment (R.J.F.): it was hoped that date would indicate time required for construction of this fresh-appearing pingo; result sheds little light on age of pingo but gives indication of time of deglaciation. (One 3day count.) 


\section{GSC-1086. Amer Lake}

Peat, $2.5 \mathrm{~m}$ below surface in hillside gully, $\mathrm{S}$ shore unnamed lake $16 \mathrm{~km} \mathrm{SW}$ of Amer Lake, N.W.T. (65 $35^{\circ} 33^{\prime}$ N Lat, 97 $37^{\prime} \mathrm{W}$ Long), alt ca. $140 \mathrm{~m}$. Water pump used to cut gully through permanently frozen sand; local permafrost table at $45 \mathrm{~cm}$. Gully exposed strata-bound peaty lenses. Coll. 1968 by B. C. McDonald. Comment (B.C.M.): sediment had been interpreted as subaqueous deposit relating to a higher local water level; date might have approximated time of deglaciation. Young date indicates sand and peat were deposited by solifluction. $\mathrm{NaOH}$-leach omitted from sample pretreatment.

\section{Southampton Island series}

Marine shells from 2 localities on Southampton I., N.W.T. Coll. 1966 by J. B. Bird, McGill Univ., Montreal.

\section{GSC-782. Southampton Island (I)}

$6930 \pm 150$

Pelecypod shell fragments (mainly Mya truncata) from surface of crest of end moraine, N-central Southampton I., N.W.T. $\left(64^{\circ} 43^{\prime} \mathrm{N}\right.$ Lat, $84^{\circ} 46^{\prime} \mathrm{W}$ Long), alt $115 \mathrm{~m}$. Sample mixed with dead gas for counting. (One 3-day count.)

GSC-838. Southampton Island (II)

$6890 \pm 210$

4940 B.c.

Shells (Mya truncata) in sand and gravel $20 \mathrm{~km} \mathrm{NE}$ of Coral Harbour, E-central Southampton I., N.W.T. $\left(64^{\circ} 17^{\prime} \mathrm{N}\right.$ Lat, $82^{\circ} 57^{\prime} \mathrm{W}$ Long), alt ca. $145 \mathrm{~m}$. Due to small sample $(6.1 \mathrm{~g})$, only outer $10 \%$ removed by leaching. Sample mixed with dead gas for counting. (One 4-day count.)

General Comment (J.B.B.): samples, from within $15 \mathrm{~m}$ of limit of postglacial marine submergence in both localities, are compatible with similar dated samples on Southampton I. and on mainland to $\mathrm{W}$ and NW (Bird, 1970; cf. also Craig, 1965; Wagner, 1967). They indicate most of island was deglaciated between 7500 and 7000 B.P.

GSC-1024. 'Widestrand Bay', Gilmour Island

$6450 \pm 140$

Articulated marine shells (Mytilus edulis) in situ between beds of marine algae on Gilmour I., Ottawa Is., N.W.T. $\left(49^{\circ} 47^{\prime} \mathrm{N}\right.$ Lat, $79^{\circ}$ $49.4^{\prime}$ W Long), in stream sec. at alt $33 \mathrm{~m} ; 8 \mathrm{~m}$ marine algae overlain by $9 \mathrm{~m}$ delta foresets. Coll. 1966 by J. T. Andrews and G. Falconer, Geog. Branch, Ottawa (now at Univ. of Colorado, Boulder, Colorado, and Surveys and Mapping Branch, Ottawa, respectively). Comment (J.T.A. and G.F.): age similar to marine shells from $39 \mathrm{~m}$ in foreset beds $(6580$ \pm 125, I-2416; Andrews, 1967; Andrews and Falconer, 1969; R., 1970, v. 12, p. 100). Both appear too old for 50-m terrace, compared to date of $4960 \pm 130$ (I-2547: ibid.), believed to date that level and lying on postglacial emergence curve for Ottawa Is. (One 3-day count.) 
D. Northern Canada, Arctic Archipelago

\section{Baffin Island}

\section{GSC-943. Clyde Inlet}

Detrital vegetation among cobbles from base of sequence of peat, sand, and gravel, $0.8 \mathrm{~km} \mathrm{~N}$ of head of Clyde Inlet, Baffin I., N.W.T. $\left(69^{\circ} 5 \mathrm{l}^{\prime} \mathrm{N}\right.$ Lat, $70^{\circ} 28^{\prime} \mathrm{W}$ Long), alt $43 \mathrm{~m}$. Sequence is overlain by a $10 \mathrm{~cm}$-thick layer of bluish clayey silt, and $2.6 \mathrm{~m}$ sand and peat, base of which dated $1860 \pm 110$ (I-1835, Andrews, 1967). Coll. 1965 by D. M. Barnett. Comment (D.M.B.): age younger than anticipated, indicating little significance for clayey silt layer, which possibly is slump material. No part of sequence can be marine, as no marine shells were found and dates are incompatible with I-1932, $7940 \pm 130$, on shells at $47 \mathrm{~m}$ (marine limit, $56 \mathrm{~m}$ ) from adjacent glacio-marine delta (Andrews, 1967; R., 1970, v. 12, p. 98) and with other dates at head of Clyde Inlet: GSC-583 (2770 $\pm 140)$, and GSC-584 (3450 \pm 170$)$, marine shells and plant debris, respectively, both at alt $6 \mathrm{~m}$, and GSC-631 $(6220 \pm 140)$, shells at alt $29 \mathrm{~m}$ (all in R., 1968, v. 10, p. 238). NaOH-leach omitted from sample pretreatment. (One 3-day count.)

\section{GSC-796. Clyde Foreland}

$40,000 \pm 1740$

Fragments of marine pelecypods (Hiatella arctica and Mya truncata) from cliff sec. $10 \mathrm{~km}$ SE of mouth of Kogalu R., Baffin I., N.W.T. $\left(70^{\circ}\right.$ $38^{\prime} \mathrm{N}$ Lat, $68^{\circ} 45^{\prime} \mathrm{W}$ Long), alt 27 to $29 \mathrm{~m}$. Shells occur above highest till; also Serripes groenlandicus, Astarte elliptica, A. borealis, A. banksii, Macoma calcarea, Chlamys islandicus, and Balanus balanus. In same layer is foraminiferal fauna characterized by high frequency of Islandiella islandica with I. teretis, Buccella frigida, B. tenerrima, and Protelphidium orbiculare commonly represented. Coll. 1966 by R. W. FeylingHanssen, Aarhus Univ., Aarhus, Denmark. Comments (R.W. F.-H.): fossil faunas and date indicate a Wisconsin interstadial age, more precisely, the Port Talbot interstadial. Absence of overlying till suggests late Wisconsin ice did not reach this locality. Lower layers in Clyde Foreland coastal cliff at Cape Christian dated as $>50,000$ B.P. (Y-1702; L $\phi$ ken, 1966). (W.B., Jr.): despite finite date, possibility of sample being of infinite age cannot be excluded (cf. Olsson and Blake, 1962; also Ives and Buckley, 1969 for discussion of GSC-796).

\section{Inner Cambridge Fiord series}

Marine pelecypod shells from 2 localities near head of Cambridge Fiord, Baffin I., N.W.T. Coll. 1968 by G. M. Haselton, Clemson Univ., Clemson, South Carolina, and D. A. Hodgson.

GSC-1094. Cambridge Fiord (I)

$6330 \pm 140$

Shells (Hiatella arctica) from surface and within marine silt form- 
ing remnant of marine terrace, alt $32 \mathrm{~m}$ on $\mathrm{W}$ side of fiord, $8 \mathrm{~km}$ from head ( $71^{\circ} 15^{\prime} \mathrm{N}$ Lat, $74^{\circ} 58^{\prime} \mathrm{W}$ Long). Local marine limit ca. $90 \mathrm{~m}$.

\section{GSC-1163. Cambridge Fiord}

$$
5500 \pm 180
$$

3550 B.C.

$$
\delta C^{13}=+0.7 \%
$$

Whole shells (Hiatella arctica and Mya truncata) from marine silt band, alt $29 \mathrm{~m}$, within deltaic deposits, surface at ca. $31 \mathrm{~m}$, at $\mathrm{E}$ front of sandur on $\mathrm{S}$ arm, head of Cambridge Fiord $\left(71^{\circ} 11^{\prime} \mathrm{N}\right.$ Lat, $75^{\circ} 03^{\prime}$ W Long). Main and highest surface of sandur has alt $44 \mathrm{~m}$ at front. General Comment (D.A.H.): samples are SE (inside) of inner, most distinctive ridge of moraine belt crossing heads of fiords in NE Baffin I.; dates are minimum for deglaciation (Hodgson and Haselton, ms. in preparation). Due to small sample $(13.5 \mathrm{~g})$, only outer $10 \%$ of GSC1163 removed by leaching. Both samples mixed with dead gas for counting. (One 3-day count and one 2-day count, respectively.)

\section{'Mid-fiord' series}

\section{GSC-1060. Kentra Bay}

$8090 \pm 140$

Marine pelecypod shells (Hiatella arctica and Mya truncata) within marine silt, alt $77 \mathrm{~m}, 4 \mathrm{~km}$ SW of head of Kentra Bay, Royal Society Fiord, Baffin I., N.W.T. ( $71^{\circ} 17^{\prime} \mathrm{N}$ Lat, $74^{\circ} 15^{\prime} \mathrm{W}$ Long). Local marine limit at alt ca. $90 \mathrm{~m}$. Coll. 1968 by D. A. Hodgson and G. M. Haselton.

\section{GSC-1064. Ranoch Arm}

$7890 \pm 160$ 5940 в.c.

Marine pelecypod shells (Hiatella arctica and Mya truncata) from frost boil in silt on uppermost terrace remnant, alt $74 \mathrm{~km}$ at head of Ranoch Arm, Cambridge Fiord, Baffin I. $\left(71^{\circ} 27^{\prime} \mathrm{N}\right.$ Lat, $75^{\circ} 08^{\prime} \mathrm{W}$ Long). Coll. 1968 by G. M. Haselton.

General Comment (D.A.H. and G.M.H.): both samples are from highest remnants of outwash on NE margin (i.e., outside) of moraine belt crossing heads of fiords in NE Baffin I. Dates are minimal for formation of oldest moraines (Hodgson and Haselton, ms. in preparation). Sample GSC-1064 mixed with dead gas for counting. (One 3-day count each.)

\section{GSC-1071. 'Pilik River'}

$2650 \pm 130$ 700 в.C.

$$
\delta C^{13}=-24.1 \%
$$

Plant material from $0.3 \mathrm{~m}$-thick layer, $3 \mathrm{~m}$ below rim of gully in stratified sand, downslope from ice-contact delta on $\mathrm{N}$ bank of 'Pilik River', Baffin I., N.W.T. ( $71^{\circ} 21^{\prime}$ N Lat, $77^{\circ} 19^{\prime}$ W Long). Coll. 1968 by D. A. Hodgson. Comment (D.A.H.): organic bed grades down-gully to laminated silt; material originally thought to have been laid down in proglacial lake. Buds, leaves, and roots (Salix sp. and Empetrum sp.), 4 mosses and 2 lichens (M. Kuc, pers. commun.), all well-preserved com- 
ponents of dry or moist dwarf shrub tundra, indicate that material is 'fossilized in situ' and represents buried tundra. (One 3-day count.)

GSC-1090. Cape Jameson

$>\mathbf{2 8 , 0 0 0}$

Thick whole valves of marine pelecypods (Hiatella arctica), alt ca. $43 \mathrm{~m}$ in river-bank exposure of marine silt, $300 \mathrm{~m}$ from present shoreline, $9 \mathrm{~km} \mathrm{~S}$ of Cape Jameson, Baffin I., N.W.T. $\left(72^{\circ} 00^{\prime} \mathrm{N}\right.$ Lat, $74^{\circ} 10^{\prime} \mathrm{W}$ Long). Coll. 1968 by D. A. Hodgson and G. M. Haselton. Comment (D.A.H.): surface above river bank dissected by marginal meltwater channels beside ice expanding onto continental shelf and foreland from Coutts Inlet-North Arm. Shells emplaced prior to glaciation. Due to small sample $(9.3 \mathrm{~g})$, only outer $10 \%$ removed by leaching. Sample mixed with clead gas for counting. Dated in 2-L counter at $1 \mathrm{~atm}$.

\section{Pond Inlet series}

Marine pelecypod shells exposed in sea cliffs at 2 localities near Pond Inlet settlement, Baffin I., N.W.T.

\section{GSC-1153. Pond Inlet (I)}

$33,100 \pm 900$

31,150 в.c.

Thick fragments (Hiatella arctica and Mya truncata) in stratified sand and silt exposed in cliff face, alt $49 \mathrm{~m}$ (cliff top alt $54 \mathrm{~m}$ ), $0.8 \mathrm{~km}$ $\mathrm{SW}$ of Pond Inlet settlement $\left(72^{\circ} 41^{\prime} \mathrm{N}\right.$ Lat, $78^{\circ} 00^{\prime} \mathrm{W}$ Long). Coll. 1968 by D. A. Hodgson. (One 2-day count.)

\section{GSC-1215. Pond Inlet (II)}

Thin fragments (Mya truncata and unidentified pelecypod) in unsorted sand and gravel exposed at cliff top, alt $30 \mathrm{~m}, 7 \mathrm{~km}, \mathrm{E}$ of Pond Inlet settlement $\left(72^{\circ} 42^{\prime} \mathrm{N}\right.$ Lat, $77^{\circ} 50^{\prime} \mathrm{W}$ Long). Coll. 1968 by D. A. Hodgson and G. M. Haselton. Mixed with dead gas for counting.

General Comment (D.A.H.): both samples probably transported by glacier, then reworked by water as postglacial beach ridges extend to alt $55 \mathrm{~m} 16 \mathrm{~km}$ to W. Cliff material considered outwash from ice front retreating $\mathrm{S}$ and $\mathrm{W}$.

\section{Devon and North Kent Islands}

\section{GSC-1072. Boat Point}

$$
\begin{gathered}
\mathbf{5 2 5 0} \pm \mathbf{1 3 0} \\
\mathbf{3 3 0 0} \text { B.C. } \\
\delta C^{13}=-22.2 \% 0
\end{gathered}
$$

Driftwood (Picea sp., id. by R. J. Mott) embedded in shingle beach $4 \mathrm{~km} \mathrm{SSW}$ of Boat Point, Devon I., N.W.T. ( $75^{\circ} 58.5^{\prime}$ N Lat, $89^{\circ} 58^{\prime}$ W Long), alt $26.5 \mathrm{~m}$. Coll. 1967 by W. Blake, Jr. Comment (W.B., Jr.): wood occurs $<0.6 \mathrm{~m}$ above pumice piece of type widely distributed around. W end of Jones Sound; date, with series for Cape Storm and South Cape Fiord, Ellesmere I. (this list), indicates age of pumice is close to $5000 \mathrm{yr}$ (Blake, 1970). (One 3-day count.)

\section{GSC-1128. Lyall River}

$8430 \pm 140$

Marine pelecypod shells (Mya truncata) from surface, W side Lyall 
R., ca. $10 \mathrm{~km} \mathrm{SW}$ of Whitmore Point, Grinnell Peninsula, Devon I., N.W.T. (76 $57.5^{\prime} \mathrm{N}$ Lat, $95^{\circ} 22^{\prime} \mathrm{W}$ Long), alt $94 \pm 5 \mathrm{~m}$. Coll. 1967 by W. W. Nassichuk for W. Blake, Jr. Comment (W.B., Jr): dated shells, within $30 \mathrm{~m}$ of marine limit, are minimum for deglaciation of $\mathrm{N}$ Grinnell Peninsula. (One 3-day count.)

\section{GSC-907. North Kent Island}

$9780 \pm 200$

7830 в.c.

Pelecypod-shell fragments (mainly Hiatella arctica and Mya truncata) in and on surface of reddish brown silt, $\mathrm{W}$ side of unnamed river $6.5 \mathrm{~km}$ WSW of DeLacy Head, North Kent I., N.W.T. $\left(76^{\circ} 49^{\prime} \mathrm{N}\right.$ Lat, $90^{\circ} 13^{\prime}$ W Long), alt ca. 95 to $107 \mathrm{~m}$. Coll. 1967 by W. Blake, Jr. Comment (W.B., Jr.): shells, poorly preserved (none whole, considerable wearing and pitting) are older than those at Lyall R. (GSC-1128; 8430 \pm 140 ) and Okse Bay (GSC-840; $8590 \pm 150$ ), both in this list, although all samples are from similar alt. Possibility that postglacial shells are mixed with older shells plastered onto $\mathrm{N}$ coast of island by ice flowing toward SE cannot be excluded. Sample mixed with dead gas for counting.

\section{Ellesmere Island}

\section{GSC-865. Goose Fiord}

Marine shell fragments (mainly Hiatella arctica) in till on ground surface ca. $10 \mathrm{~km} \mathrm{NNW}$ of head of Goose Fiord, Ellesmere I., N.W.T. ( $76^{\circ} 54^{\prime} \mathrm{N}$ Lat, $88^{\circ} 38^{\prime} \mathrm{W}$ Long), alt ca. 98 to $101 \mathrm{~m}$. Coll. 1967 by W. Blake, Jr. Comment (W.B., Jr.): date is minimum for shells believed transported inland by ice flowing through low valley from Norwegian Bay to Goose Fiord during last glacial maximum (Blake, 1970). Sample mixed with dead gas for counting. (One 4-day count.)

Muskox Fiord series (I)

GSC-879. Muskox Fiord, peat

Peat (mainly Drepanocladus badius [C. J. Hartm.], id. by G. R. Brassard, Univ. of Ottawa, Ottawa), from steeply dipping layers exposed on surface of sand deposit along creek ca. $7.2 \mathrm{~m} \mathrm{NW}$ of head of Muskox Fiord, Ellesmere I., N.W.T. ( $76^{\circ} 40.5^{\prime} \mathrm{N}$ Lat, $87^{\circ} 45^{\prime} \mathrm{W}$ Long), alt ca. 95 m. Coll. 1967 by W. Blake, Jr. Two fractions (cf. R., 1970, v. 12, p. 49):

more soluble in $\mathrm{NaOH}$ (two 1-day counts)

$4830 \pm 160$

less soluble in $\mathrm{NaOH}$ (one 4-day count)

$4700 \pm 130$

Comment (W.B., Jr.): date indicates section of valley above and $0.8 \mathrm{~km}$ NW of highest postglacial marine features was ice free by $4800 \mathrm{yr}$ B.P. $\mathrm{NaOH}$-soluble fraction mixed with dead gas for counting.

GSC-864. Muskox Fiord, shells

Fragments of marine pelecypods (Hiatella arctica, Mya truncata, and Macoma sp.) from surface and embedded in till ca. $1 \mathrm{~km} \mathrm{NW}$ of

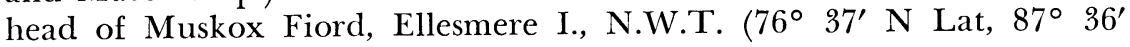


W Long), alt ca. 165 to $185 \mathrm{~m}$. Coll. 1967 by W. Blake, Jr. Comment (W.B., Jr.): dated shells, high above limit of postglacial marine submergence in area (ca. $90 \mathrm{~m}$ ), were emplaced by valley glacier flowing $\mathrm{S}$ across former marine embayment $\mathrm{N}$ of head of Muskox Fiord. Due to lab. error for this small sample $(11.1 \mathrm{~g})$, outer $40 \%$ of shell was removed by leaching instead of $10 \%$. Sample mixed with dead gas for counting. (One 4-day count.)

\section{Cape Storm series (I)}

Driftwood logs, id. by R. J. Mott, from emerged beaches ca. 5 to $6.5 \mathrm{~km}$ NNE of Cape Storm, Ellesmere I., N.W.T. Coll. 1967 by W. Blake, Jr.

\section{GSC-845. C. Storm, wood, $71.0 \mathrm{~m}$}

Picea sp. $\left(76^{\circ} 24.5^{\prime} \mathrm{N}\right.$ Lat, $87^{\circ} 33^{\prime} \mathrm{W}$ Long).

GSC-873. C. Storm, wood, $50.5 \mathrm{~m}$

$$
\begin{array}{r}
8300 \pm 140 \\
6350 \text { B.C. } \\
\delta C^{13}=-23.5 \% \circ \\
7700 \pm 140 \\
\mathbf{5 7 5 0 ~ B . C .} \\
\delta C^{1 s}=-21.4 \% o
\end{array}
$$

Picea sp. $\left(76^{\circ} 23.5^{\prime} \mathrm{N}\right.$ Lat, $87^{\circ} 35^{\prime} \mathrm{W}$ Long). Uncertainty mistakenly given as \pm 150 in Blake (1970).

GSC-835. C. Storm, wood, $43.5 \mathrm{~m}$

Picea sp. (76 $24^{\prime}$ N Lat, $87^{\circ} 32^{\prime}$ W Long).

GSC.-833. C. Storm, wood, $33.5 \mathrm{~m}$

Picea sp. (76 $24^{\prime}$ N Lat, $87^{\circ} 31^{\prime} \mathrm{W}$ Long).

GSC-1007. C. Storm, wood, $31.5 \mathrm{~m}$ tions:
$7280 \pm 140$

5330 B.c.

$\delta C^{18}=-20.5 \%$

$6480 \pm 140$

4530 B. $\mathrm{C}$.

$\delta C^{13}=-23.2 \%$

$$
\begin{aligned}
& 6150 \pm 130 \\
& 4200 \text { B.C. }
\end{aligned}
$$$$
\delta C^{13}=-21.3 \%
$$

one 4-day count in 5-L counter at $1 \mathrm{~atm}$.

one 1 -day count of same gas in $2-\mathrm{L}$ counter at $1 \mathrm{~atm}$

$$
\begin{aligned}
& 6150 \pm 130 \\
& 6120 \pm 190
\end{aligned}
$$

\section{GSC.928. C. Storm, wood, $27.5 \mathrm{~m}$}

Picea or Larix $\left(76^{\circ} 24^{\prime} \mathrm{N}\right.$ Lat, $87^{\circ} 31^{\prime} \mathrm{W}$ Long).

\section{GSC.986. C. Storm, wood, $24.0 \mathrm{~m}$}

Picea or Larix $\left(76^{\circ} 22.5^{\prime} \mathrm{N}\right.$ Lat, $87^{\circ} 32^{\prime} \mathrm{W}$ Long).

$5720 \pm 140$

3770 B.C.

$\delta C^{13}=-22.7 \%$

$5200 \pm 140$

3250 в.C.

$\delta C^{13}=-23.6 \%$ 
$\begin{array}{ll}\text { GSC-826. C. Storm, wood, } 22.5 \mathrm{~m} & \begin{array}{c}3150 \text { B.c. } \\ \delta C^{13}=-21.7 \% 0\end{array}\end{array}$

$5100 \pm 130$

Picea or Larix ( $76^{\circ} 24^{\prime} \mathrm{N}$ Lat, $87^{\circ} 30^{\prime} \mathrm{W}$ Long). (One 4-day count.)

\section{GSC-921. C. Storm, wood, $20.5 \mathrm{~m}$}

Picea sp. (76 $22.5^{\prime} \mathrm{N}$ Lat, $87^{\circ} 32^{\prime} \mathrm{W}$ Long).

\section{GSC-839. C. Storm, wood, $17.5 \mathrm{~m}$}

Picea sp. ( $76^{\circ} 23^{\prime} \mathrm{N}$ Lat, $87^{\circ} 30^{\prime} \mathrm{W}$ Long).

General Comment (W.B., Jr.): dates on logs embedded in shingle beaches show rate of uplift decreasing with time. GSC-826, ca. $0.5 \mathrm{~m}$ above level of abundant pumice, indicates (with dates from South Cape Fiord and Boat Point, this list) pumice is ca. $5000 \mathrm{yr}$ old (Blake, 1970). (GSC-835, $-845,-921,-928$, and -986 each based on one 3-day count.)

\section{'Basement Cove' series}

Driftwood and marine algae embedded in shingle beaches at 'Basement Cove', ca. $18 \mathrm{~km}$ ESE of mouth of Baad Fiord, Ellesmere I., N.W.T. (76 $21.5^{\prime} \mathrm{N}$ Lat, $85^{\circ} 43^{\prime}$ W Long). Coll. 1967 by W. Blake, Jr.

\section{GSC-823. 'Basement Cove', driftwood}

$$
\begin{array}{r}
\mathbf{5 7 4 0} \pm \mathbf{1 4 0} \\
\mathbf{3 7 9 0} \text { B.C. } \\
\delta C^{13}=-22.7 \% \text { o }
\end{array}
$$

Driftwood (Picea or Larix, id. by R. J. Mott) embedded in surface of beach shingle, alt $19.0 \mathrm{~m}$.

\section{GSC-863. 'Basement Cove', marine algae}

$$
\begin{aligned}
\mathbf{4 7 4 0} \pm 140 \\
\mathbf{2 7 9 0} \text { B.C. } \\
\delta C^{13}=-18.4 \% 0
\end{aligned}
$$

Marine algae (Desmarestia sp., id. by R. K. S. Lee, Natl. Mus. Nat. Sci., Ottawa) embedded in layer at 0.6 to $0.7 \mathrm{~m}$ depth in beach gravel, alt $14.0 \mathrm{~m}$.

General Comment (W.B., Jr.): dates indicate that shoreline formed ca. $5000 \mathrm{yr}$ ago (= time of pumice deposition, Blake, 1970) is between alts of 2 samples.

\section{South Cape Fiord series (I)}

Driftwood logs, id. by R. J. Mott, on W side of South Cape Fiord, Ellesmere I., N.W.T. (76 $26^{\circ} \mathrm{N}$ Lat, $85^{\circ} 00^{\prime} \mathrm{W}$ Long). Coll. 1968 by W. Blake, Jr.

GSC-1225. South Cape Fiord, wood, $42.0 \mathrm{~m}$ 
GSC-1080. South Cape Fiord, wood, $31.0 \mathrm{~m}$

Picea sp.

GSC-1047. South Cape Fiord, wood, $17.0 \mathrm{~m}$

Picea sp.

GSC-1078. South Cape Fiord, wood, $16.0 \mathrm{~m}$

Picea sp.

GSC-1148. South Cape Fiord, wood, $12.5 \mathrm{~m}$

Picea or Larix.

GSC-1320. South Cape Fiord, wood, $6.0 \mathrm{~m}$

Picea sp.

General Comment (W.B., Jr.): dates on logs embedded in shingle beaches (except for GSC-1320, which was lying loose adjacent to its imprint) show decreasing rate of uplift with time. GSC-1047, ca. $0.3 \mathrm{~m}$ below average alt of pumice at locality, corroborates dates from Boat Point and Cape Storm (this list), suggesting pumice is ca. 5000 yr old (Blake, 1970). (GSC-1047, -1078, and -1080 each based on one 3-day count.)

\section{GSC-840. Okse Bay}

$8590 \pm 150$

6640 B.C.

Pelecypod shell fragments (Hiatella arctica and Mya truncata) from surface and embedded in sand and silt of sorted polygons $1.6 \mathrm{~km} \mathrm{~W}$ of

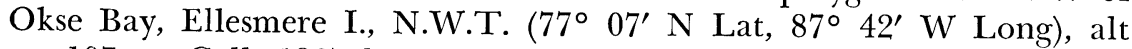
ca. 107 m. Coll. 1967 by W. Blake, Jr. Comment (W.B., Jr.): date on shells, highest coll. in area, is minimum for deglaciation, and is approx. age of highest postglacial marine features.

GSC-1206. Macdonald River

$>37,000$

Driftwood, poorly preserved (probably Thuja sp., id. by R. J. Mott) $4 \mathrm{~cm}$ diam., $30 \mathrm{~cm}$ long, from NE side of Macdonald R., Tanquary Fiord, Ellesmere I., N.W.T. (81 ${ }^{\circ} 25^{\prime} \mathrm{N}$ Lat, $76^{\circ} 15^{\prime} \mathrm{W}$ Long) in postglacial delta, $5 \mathrm{~m}$ below top of $78 \mathrm{~m}$ high river bank. Wood enclosed in, and $30 \mathrm{~cm}$ below top of, foresets dipping downriver, which are overlain by $3.25 \mathrm{~m}$ eolian sand and peat, the latter $2970 \pm 130 \mathrm{yr}$ old (SI-575; Mielke and Long, 1969). It was hoped that wood age would provide chec:: on dated marine shells in vicinity (Hattersley-Smith and Long, 1967). Coll. 1969 by G. Hattersley-Smith, Defence Research Bd., Ottawa. Comment (G.H-S.): driftwood was transported from up-river. Other 
wood pieces, probably deriving from Beaufort Formation, occur in Macdonald R. valley up to alt $570 \mathrm{~m}$, Hattersley-Smith, 1969).

\title{
4. Other Islands
}

GSC-1138. Thompson Glacier, Axel Heiberg Island 3740 в.c.

Driftwood embedded in silt and clay of morainic deposits, distal part of push moraine of advancing Thompson Glacier, Axel Heiberg I., N.W.T. $\left(79^{\circ} 25^{\prime} 30^{\prime \prime} \mathrm{N}\right.$ Lat, $90^{\circ} 37^{\prime} \mathrm{W}$ Long), alt ca. $95 \mathrm{~m}$. Original location of sample estimated ca. $0.8 \mathrm{~km}$ up-valley, in area now covered by Thompson Glacier. Coll. 1968 by A. Gansser, ETH, Zurich, Switzerland; subm. by F. Müller. Comment (F.M.): date agrees with others on driftwood (B-431, $5480 \pm 100 ;$ B-432, $5920 \pm 100$; GX-0144, $5325 \pm$ 227) assoc. with same push moraine. Some 6000 to $5000 \mathrm{yr}$ ago, sea extended up-valley from present position of Thompson Glacier terminus. Vertical uplift by bulldozing effect of glacier amounts to ca. $50 \mathrm{~m}$ (cf. Müller, 1963; 1966).

\section{GSC-619. Meighen Island}

$8610 \pm 190$

Marine pelecypod shells (mainly Hiatella arctica) from $\mathrm{S}$ of ice-cap on Meighen I., N.W.T. ( $\left(9^{\circ} 44.7^{\prime} \mathrm{N}\right.$ Lat, $98^{\circ} 46^{\prime} \mathrm{W}$ Long), alt ca. $12 \mathrm{~m}$. Coll. 1962 by K. C. Arnold (now with Inland Waters Branch, Dept. Energy, Mines and Resources, Ottawa); subm. by J. G. Fyles. Comment (W.B., Jr.): date, only one from Meighen I. is minimum for deglaciation and is similar to dates on Ellef Ringnes I. to SW (St-Onge, 1965). Date may approx. age of highest postglacial marine features, which, according to Fyles (cf. Blake, 1970), are probably $<30 \mathrm{~m}$ alt. Sample mixed with dead gas for counting.

\section{GSC-999. Cape Nathorst, Ellef Ringnes Island}

$8320 \pm 140$

Driftwood log (Picea or Larix, id. by R. J. Mott), ca. $20 \mathrm{~cm}$ diam., embedded and frozen in disintegrated shale, $12 \mathrm{~km} \mathrm{NE}$ of C. Nathorst, Ellef Ringnes I., N.W.T. ( $77^{\circ} 52^{\prime} 45^{\prime \prime}$ N Lat, $99^{\circ} 38^{\prime} \mathrm{W}$ Long), at alt 25 $\pm 5 \mathrm{~m}$. Coll. 1967 by D. A. St-Onge. Comment (D.A. St.-O): date confirms $\mathrm{L}-643 \mathrm{~A}, 8500 \pm 200$, on surface shells at ca. $33 \mathrm{~m}$ nearby to NE (StOnge, 1965; Blake, 1970). (One 3-day count.)

\section{GSC-1193. Resolute, Cornwallis Island}

$7380 \pm 140$ 5430 B.c.

$$
\delta C^{13}=-14.8 \%
$$

Whale bone (vertebra) embedded in sand and gravel of shingle beach ca. $1.6 \mathrm{~km} \mathrm{NW}$ of Eskimo Village at Resolute, Cornwallis I., N.W.T. ( $74^{\circ} 42^{\prime} \mathrm{N}$ Lat, $94^{\circ} 59^{\prime} \mathrm{W}$ Long), at alt ca. $50 \mathrm{~m}$. Coll. 1968 by F. Müller, McGill Univ., Montreal. Two determinations:

\author{
GSC-1193. Collagen fraction \\ Treated in $0.1 \mathrm{~N} \mathrm{NaOH}$ for $24 \mathrm{hr}$.
}

$7380 \pm 140$ 
GSC-1193-2. Collagen fraction

$7570 \pm 140$

Treated in $0.1 \mathrm{~N} \mathrm{NaOH}$ for $1 \mathrm{hr}$.

Comment (W.B., Jr.): date, with 2 on shells near Resolute (Blake, 1970), indicates that following deglaciation, rate of uplift has decreased with time. Much of porous and discolored (brown) bone contained fragments of moss, rootlets, and other organic material. Sample cut into small pieces and washed in distilled water to remove organic material by flotation. (One 3-day count each.)

\section{Caledonian River series, Bathurst Island}

Shell fragments (Mya truncata) from layers containing many paired individuals in situ, in exposure on $\mathrm{N}$ side Caledonia $\mathrm{R}$., $0.8 \mathrm{~km} \mathrm{E}$ of head of 'Dartmouth Bight', Bracebridge Inlet, Bathurst I., N.W.T. (75' $41^{\prime}$ N Lat, $98^{\circ} 48^{\prime}$ W Long). Coll. 1963 by W. Blake, Jr.

\section{GSC-783. Caledonian River, upper shell layer

Shells from zone at alt ca. $25 \mathrm{~m}$ overlying silt and underlying 0.6 to $2 \mathrm{~m}$ sand and gravel. $5 \mathrm{~m}$ gravel alt ca. $23 \mathrm{~m}$, underlying silt and overlying ca. part gravel above ca. $12 \mathrm{~m}$ sand and silt with organic layers in upper part.

General Comment (W.B., Jr.): occurrence of 2 shell-bearing sand and gravel layers separated by silt suggests water depth increased or character of sedimentation changed during $3000 \mathrm{yr}$ interval separating 2 deposits. Shoreline $5000 \mathrm{yr}$ ago was above $25 \mathrm{~m}$ (Blake, 1970). GSC-736 mixed with dead gas for counting. (One 3-day count.)

\section{Fitzwilliam Owen Island series}

Marine shells and driftwood, S side of Fitzwilliam Owen I., N.W.T. ( $77^{\circ} 08^{\prime} \mathrm{N}$ Lat, $113^{\circ} 48^{\prime}$ W Long). Coll. 1968 by M. Kuc.

\section{GSC-1123. Fitzwilliam Owen Island, shells $\quad 8150$ B.c.}

Whole shells and fragments (Hiatella arctica) from horizon, alt ca. $20 \mathrm{~m}$, widespread up to ca. $25 \mathrm{~m}$ alt, within summit depression of island (between highest hills, which rise to ca. $37 \mathrm{~m}$ ). Shell horizon overlain and underlain by marine silt and clay containing sand lentils. (One 3-day count.)

\section{GSC-1171. Fitzwilliam Owen Island, wood}

$$
\begin{aligned}
& 7850 \pm 140 \\
& \mathbf{5 9 0 0} \text { в.c. }
\end{aligned}
$$

Upright driftwood log (Picea or Larix, R. J. M ott) in marine area partly modified driftwood found on island. 
General Comment (W. B., Jr.): date on shells indicates island was icefree 10,000 yr ago; oldest postglacial dates on shells from nearby areas are 11,160 \pm 150 (GSC-260) for NE Prince Patrick I. and 10,580 \pm 260 (GSC-352) for SE Borden I. (both in R., 1967, v. 9, p. 193). Date on wood indicates considerably less uplift occurred in last 7700 to $8000 \mathrm{yr}$ than in areas to $\mathrm{E}$ that were covered by thicker ice (Blake, 1970). For development of vegetation see Kuc (1971).

\section{E. Svalbard}

\section{Vestre Tvillingneset series, Nordaustlandet}

Driftwood from W side of Vestre Tvillingneset, Nordaustlandet, Svalbard $\left(80^{\circ} 02.5^{\prime} \mathrm{N}\right.$ Lat, $18^{\circ} 08^{\prime} \mathrm{E}$ Long), alt between 7 and $8 \mathrm{~m}$. Coll. 1958 (GSC-1117) and 1966 (GSC-1345) by W. Blake, Jr.

\section{GSC-1117. Vestre Tvillingneset, 8-1958}

$$
\begin{aligned}
& 6240 \pm 160 \\
& 4290 \text { B.C. }
\end{aligned}
$$

Driftwood (Larix sp.) log embedded in beach gravel and sand, only $\log$ coll. at site in 1958. Original date by Uppsala Univ. was $6200 \pm 100$ (U-107; Olsson, 1960; Blake, 1961); date recalculated using .95 of activity of NBS oxalic acid as standard was $6330 \pm 110$ (I. U. Olsson, 1966, written commun.). However, age obtained on part of sample sent to Gakushuin Univ., was $6910 \pm 140$ (Gak-1909; based on one 19-hr count (K. Kigoshi, 1968, written commun.). (Three 1-day counts in 5-L counter at $1 \mathrm{~atm}$.

\section{GSC-1345. Vestre Tvillingneset, 193-1966}

$$
\begin{gathered}
\mathbf{6 3 9 0} \pm 140 \\
\mathbf{4 4 4 0} \text { B.c. } \\
\delta C^{13}=-22.0 \%
\end{gathered}
$$

Re-collection of same $\log$ (one of several in area, but only one had been sawed and coll. in 1958) in 1966. Three age determinations, all using same gas (cf. Table 2, this list):

two 1-day counts in 5-L counter at 1 atm

two 1-day counts in 2-L counter at 2 atm

$$
\begin{aligned}
& 6390 \pm 140 \\
& 6500 \pm 150 \\
& 6340 \pm 250
\end{aligned}
$$

two 1-day counts in 1-L counter at $1 \mathrm{~atm}$

Age obtained by Gakushuin on part of sample was $5350 \pm 170$ (GaK-1409; based on one 19-hr count; K. Kigoshi, 1967, written commun.).

General Comment (W.B., Jr.): agreement between determinations made by Uppsala and GSC on original sample is within limits of error (Uppsala dates are given with $\pm 1 \sigma$ and are corrected for isotopic fractionation), but result obtained by Gakushuin is too old. Agreement between 3 GSC determinations on 1966 coll. and original sample is also within limits of error; agreement dispelled doubts which arose on receipt of GaK-1409, $5350 \pm 170$, that submitter had mixed 1966 samples. Gakushuin determinations on same $\log$ are thus $5350 \pm 170$ (GaK-1409) and $6910 \pm 140$ (Gak-1909); all GSC and Uppsala dates range between 6080 
and 6650. Possibly fact that small amounts of carbon from previous samples were discovered at times to be adhering to walls of stainless steel 'reaction tubes' (K. Kigoshi, 1969, written commun.) is cause of discrepancy between Gakushuin dates and those from other labs.

\section{GSC-1218. Zordragerfjorden, Nordaustlandet}

$17,700 \pm 200$

15,750 в.c.

$\delta C^{13}=+2.7 \%$

Marine pelecypod shells and fragments (mainly Hiatella arctica and Mya truncata) from fines on surface of sorted polygons adjacent to unnamed pond, E side Zordragerfjorden, Nordaustlandet, Svalbard $\left(80^{\circ}\right.$ $24.5^{\prime} \mathrm{N}$ Lat, $22^{\circ} 52^{\prime} \mathrm{E} \mathrm{Long}$ ), alt 34 to $35 \mathrm{~m}$. Shells worn, rounded, and mostly fragmented though many were thick; some were chalky, some had slight lichen growth or attached algae(?), and some were discolored (none with incrustations subm.). In general, shells had appearance of "old" type, i.e., those ante-dating last glaciation( >30,000 yr). Coll. 1966 by W. Blake, Jr. Comment (W.B., Jr.): date obtained by Gakushuin Univ. on part (45 g) of same sample (142-1966) was $16,240 \pm 360$ (Gak1405), based on one 23-hr count after removal of outer ca. $10 \%$ of shells (K. Kigoshi, 1967, written commun.). Since alt is below limit of postglacial marine submergence, age should not have exceeded $11,000 \mathrm{yr}$, judging by other dates from Nordaustlandet. Interpretations possible are: 1) sample is mixture of postglacial shells with "old" shells found in many places on island (Blake, 1961). If so, results from GSC and Gakushuin agree as closely as can be expected; such good agreement is probably fortuitous; 2) sample is composed entirely of "old" shells, contaminated in some way to produce apparent ages of 16,000 to 18,000 yr; e.g., $10 \%$ contamination with contemporary carbon of shells ca. $45,000 \mathrm{yr}$ old would cause error in age of $25,000 \mathrm{yr}$ (Olsson and Blake, 1962); 3) sample is made up of shells 16,000 to $18,000 \mathrm{yr}$ old, thus area must have been ice free then. Third alternative seems least likely, despite site location in N-most Nordaustlandet, near margin of former ice sheet; sea level then (close to maximum of last glaciation) is known from evidence elsewhere to have been $8 \mathrm{~m}$ or more below its present level (Shepard and Curray, 1967; Milliman and Emery, 1968). Pretreatment of GSC-1218 was standard removal of outer $20 \%$ of shell (32 $\mathrm{g} \mathrm{subm}$.) in HCl. (One 3-day count.)

REFERENCES

Achard, R. A., 1970, Quaternary geology, Big Bend-Canoe River, British Columbia, in: Report of activities, Part A, April to October, 1969: Canada, Geol. Survey Paper 70-1, pt. A, p. 165-166.

Andrews, J. T., 1967, Radiocarbon dates obtained through Geographical Branch field observations: Canada, Geog. Br., Geog. Bull., v. 9, p. 115-162.

Andrews, J. T. and Falconer, George, 1969, Late glacial and postglacial history and emergence of the Ottawa Islands, Hudson Bay, N.W.T.: Evidence on the deglaciation of Hudson Bay: Canadian Jour. Earth Sci., v. 6, p. 1263-1276.

Armstrong, J. E., Crandell, D. R., Easterbrook, D. J., and Noble, J. B., 1965, Late Pleistocene stratigraphy and chronology in southwestern British Columbia and northwestern Washington: Geol. Soc. America Bull., v. 76, p. 321-330. 
Berger, Rainer and Libby, W. F., 1966, UCLA radiocarbon dates V: Radiocarbon, v. 8, p. $467-497$.

Bird, J. B., 1970, The final phase of the Pleistocene ice sheet north of Hudson Bay, in: Problemy Czwartorzedu (Problèmes du Quaternaire): Acta Geographica Lodziensia no. 24, Lódzkie Towarzystwo Naukowe, ser. III, p. 75-89.

Blake, W., Jr., 1956, Landforms and topography of the Lake Melville area, Labrador, Newfoundland: Canada, Geog. Br., Geog. Bull. no. 9, p. 75-100.

1961, Radiocarbon dating of raised beaches in Nordaustlandet, Spitsbergen, in: Raasch, G. O. (ed.), Geology of the Arctic: 1st internatl. symposium on Arctic Geol. Proc., Calgary, Alberta, 1960: Toronto, Univ. of Toronto Press, p. 133-145. 1970, Studies of glacial history in Arctic Canada. I. Pumice, radiocarbon dates, and differential postglacial uplift in the eastern Queen Elizabeth Islands: Canadian Jour. Earth Sci., v. 7, p. 634-664.

Bostock, H. S., 1966, Notes on glaciation in central Yukon Territory: Canada, Geol. Survey Paper 65-36, 18 p.

Brookes, I. A., 1969, Late-glacial marine overlap in western Newfoundland: Canadian Jour. Earth Sci., v. 6, p. 1397-1404. 1970a, The glaciation of southwestern Newfoundland: Ph.D. dissert., McGill Univ., Montreal, Québec, 208 p. $1970 \mathrm{~b}$, New evidence for an independent Wisconsin-age ice cap over Newfoundland: Canadian Jour. Earth Sci., v. 7, p. 1374-1382.

Buckley, J. D. and Willis, E. H., 1970, Isotopes' radiocarbon measurements VIII: Radiocarbon, v. 12, p. 87-129.

Campbell, C. A., Paul, E. A., Rennie, D. A., and McCallum, K. J., 1967a, Factors affecting the accuracy of the carbon-dating method in soil humus studies: Soil Science, v. 104, p. 81-85.

1967b, Applicability of the carbon-dating method of analysis to soil humus studies: Soil Science, v. 104, p. 217-224.

Churcher, C. S., 1968, Mammoth from the Middle Wisconsin of Woodbridge, Ontario: Canadian Jour. Zool., v. 46, p. 219-221.

Clarke, A. H., Jr., 1965, The scallop superspecies Aequipecten irradians (Lamarck): Malacologia, v. 2, p. 161-188.

Clarke, A. H., Jr., Stanley, D. J., Medcof, J. C., and Drinnan, R. E., 1967, Ancient oyster and bay scallop shells from Sable Island: Nature, v. 215, no. 5106, p. $1146-1148$.

Craig, B. G., 1965, Notes on moraines and radiocarbon dates in northwest Baffin Island, Melville Peninsula and northeast District of Keewatin: Canada, Geol. Survey Paper 65-20, 7 p.

1969, Late-glacial and postglacial history of the Hudson Bay region, in: Hood, P. J. (ed.), Earth science symposium on Hudson Bay: Canada, Geol. Survey Paper 68-53, p. 63-77.

Crawford, C. B. and Sutherland, J. G., 1971, The Empress Hotel-Sixty-five years of foundation settlements: Canadian Geotech. Jour., v. 8, p. 77-93.

David, P. P., 1971, The Brookdale Road section and its significance in the chronological studies of dune activities in the Brandon Sand Hills of Manitoba: Geol. Assoc. Canada, Spec. Paper no. 9.

David, P. P., Pollen production rates and dune activities on the Canadian Prairies: ms. in preparation.

Dreimanis, Aleksis, 1969, La dernière Glaciation dans la Region orientale des Grand Lacs, Amerique du Nord: Résumés des Commun., 8th cong. INQUA, Paris, p. 192.

Dreimanis, Aleksis and Karrow, P. F., 1965, Southern Ontario, in Great Lakes-Ohio River Valley: Guidebook, Field conf. G, 7th cong. INQUA, Boulder and Denver, Colorado, p. $90-110$.

Dreimanis, A., Terasmae, J., and McKenzie, G. D., 1966, The Port Talbot Interstade of the Wisconsin Glaciation: Canadian Jour. Earth Sci., v. 3, p. 305-325.

Dyck, Willy and Fyles, J. G., 1962, Geological Survey of Canada radiocarbon dates I: Radiocarbon, v. 4, p. 13-26.

1963, Geological Survey of Canada radiocarbon dates II: Radiocarbon, v. 5, p. $39-55$.

1964, Geological Survey of Canada radiocarbon dates III: Radiocarbon, v. 6 , p. 167-181.

Dyck, Willy, Fyles, J. G., and Blake, W., Jr., 1965, Geological Survey of Canada radiocarbon dates IV: Radiocarbon, v. 7, p. 24-46. 
Dyck, Willy, Lowdon, J. A., Fyles, J .G., and Blake, W., Jr., 1966, Geological Survey of Canada radiocarbon dates V: Radiocarbon, v. 8, p. 96-127.

Elson, J. A., 1960, Surficial geology, Brandon, West of Principal Meridian, Manitoba: Canada, Geol. Survey Map 1067A.

1967, Geology of Glacial Lake Agassiz, in: Mayer-Oakes, W. J. (ed.), Life, land and water; 1966 conf. on environmental studies of the Glacial Lake Agassiz Region Proc.: Occasional Papers, Dept. of Anthropol., Univ. of Manitoba, no. 1: Winnipeg, Univ. of Manitoba Press, p. 37-95.

Fulton, R. J., 1968, Olympia interglaciation, Purcell trench, British Columbia: Geol. Soc. America Bull., v. 79, p. 1075-1080.

Fulton, R. J. and Klassen, R. W., 1969, Quaternary geology, northwest District of Mackenzie, in: Report of activities, Part A, April to October 1968: Canada, Geol. Survey Paper 69-1, pt. A, p. 193-194.

Fyles, J. G., 1966, Quaternary stratigraphy, Mackenzie delta and Arctic coastal plain, in: Report of activities, May to October, 1965: Canada, Geol. Surv. Paper 66-1,
p. 30-31.

Part A, May to Mackenzie delta and Arctic coastal plain, in: Report of activities,

Part A, May to October, 1966: Canada Geol. Surv. Paper 67-1, pt. A, p. 34-35. 1965, Pleistocene Dreimanis, Aleksis, Forsyth, J. L., Karrow, P. F., and White, G. W. 1965, Pleistocene deposits of the Erie lobe, in: Wright, H. E., Jr., and Frey, D. G. (eds.), The Quaternary of the United States: Princeton, New Jersey, Princeton
Univ. Press, p. 85-97.

Grant, D. R., 1969a, Surficial deposits, geomorphic features, and late Quaternary history of the terminus of the northern peninsula of Newfoundland and adjacent Quebec-Labrador: Maritime Sediments, v. 5, p. 123-125. 1969b, Late Pleistocene re-advance of piedmont glaciers in western New-

Canadian 1970, Recent coastal submergence of the Maritime Provinces, Canada: Canadian Jour. Earth Sci., v. 7, p. 676-689.

Hattersley-Smith, G., 1969, Glacial features of Tanquary Fiord and adjoining areas of
northern Ello northern Ellesmere Island, N.W.T.: Jour. Glaciol., v. 8, no. 52, p. 23-50.

Hattersley-Smith, G. and Long, Austin, 1967, Postglacial uplift at Tanquary Fiord, northern Ellesmere Island, Northwest Territories: Arctic, v. 20, p. 255-260. Haynes, C. V., Jr., 1966, Radiocarbon samples: chemical removal of plant contami-
nants: Science, v. 151, p. 1391-1392. Henderson, E. P., 1960, Surficial geology, St. John's, Newfoundland: Canada, Geol.
Survey Map 35-1959.

Hobson, G. D. and Terasmae, Jaan, 1969, Pleistocene geology of the buried St. Davids gorge, Niagara Falls, Ontario: geophysical and palynological studies: Canada,
Geol. Survey Paper 68-67, 16 p.

Hodgson, D. A. and Haselton, G. M., Reconnaissance glacial geology, northeast Baffin Island: Canada, Geol. Survey Paper, ms. in preparation.

Hughes, O. L., Campbell, R. B., Muller, J. E., and Wheeler, J. O., 1969, Glacial limits and flow patterns, Yukon Territory, south of 65 degrees North Latitude: Canada, Geol. Survey Paper 68-34, 9 p.

Ives, J. D. and Buckley, J. T., 1969, Glacial geomorphology of Remote Peninsula, Baffin Island, N.W.T.: Arctic and Alpine Research, v. 1, p. 83-95.

James, N. P. and Stanley, D. J., 1967, Sediment transport on Sable Island, Nova Scotia: Smithsonian Misc. Colln., v. 152, no. 7, pub. 4723, 33 p.

Jungerius, P. D., 1969, Soil evidence of postglacial tree line fluctuations in the Cypress Hills Area, Alberta, Canada: Arctic and Alpine Research, v. 1, p. 235-246. Karrow, P. F., 1967, Pleistocene geology of the Scarborough area: Ontario Dept. Mines,
Geol. rept., no. 46, 108 p.

1969, Stratigraphic studies in the Toronto Pleistocene: Geol. Assoc. Canada Proc., v. 20, p. 4-23.

Kerfoot, D. E., 1969, The geomorphology and permafrost conditions of Garry Island, N.W.T.: Ph.D. dissert., Univ. of British Columbia, Vancouver, British Columbia,
308 p.

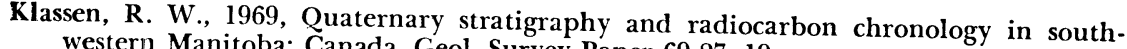
western Manitoba: Canada, Geol. Survey Paper 69-27, 19 p.

Krueger, H. W. and Weeks, C. F., 1966, Geochron Laboratories, Inc. radiocarbon measurements II: Radiocarbon, v. 8, p. 142-160. 

Kuc, Marian, 1971, Additions to the Arctic Flora. V-The role of mosses in plant Canadian Arctic): Rev. Bryolog. et Lichénolog., v. 37.

LaMarche, V. C., Jr. and Mooney, H. A., 1967, Altithermal timberline advance in western United States: Nature, v. 213, no. 5080, p. 980-982.

LaSalle, Pierre, 1968, Field trip of Quaternary geology, Saguenay River-Lac St-Jean: Contr. to ACFAS cong., 1968, 31 p.

1969, Quaternary geology of the lac Saint-Jean and Saguenay River areas, Field Trip no. 5, in: Guidebook, 1969 ann. mtg., Geol. Assoc. Canada-Mineralog. Assoc. Canada, June 1969, Montreal, p. 37-85.

LaSalle, Pierre and Rondot, Jehan, 1967, New ${ }^{14} \mathrm{C}$ dates from the Lac St-Jean area, Quebec: Canadian Jour. Earth Sci., v. 4, p. 568-571.

Lebuis, Jacques, 1971, La géologie des dunes de sable de la région du lac Saint-Jean: M.Sc. thesis, Univ. de Montréal, Montréal, Québec, $70 \mathrm{p}$.

Lewis, C. F. M., 1969, Late Quaternary history of lake levels in the Huron and Erie Basins: 12th conf. Great Lakes Research 1969 Proc., Internatl. Assoc. Great Lakes Research, p. 250-270.

1970, Recent uplift of Manitoulin Island, Ontario: Canadian Jour. Earth

Sci., v. 7, p. 665-675.
Lichti-Federovich, Sigrid, 1970, The pollen stratigraphy of a dated section of LatePleistocene lake sediment from central Alberta: Canadian Jour. Earth Sci., v. 7, p. 938-945.

Løken, O. H., 1966, Baffin Island refugia older than 54,000 years: Science, v. 153, p. 1378-1380.

Lowdon, J. A. and Blake, W., Jr., 1968, Geological Survey of Canada radiocarbon dates VII: Radiocarbon, v. 10, p. 207-245.

1970, Geological Survey of Canada radiocarbon dates IX: Radiocarbon,

v. 12, p. 46-86.
Lowdon, J. A., Fyles, J. G., and Blake, W., Jr., 1967, Geological Survey of Canada radiocarbon dates VI: Radiocarbon, v. 9, p. 156-197.

Lowdon, J. A., Wilmeth, R., and Blake, W., Jr., 1969, Geological Survey of Canada radiocarbon dates VIII: Radiocarbon, v. 11, p. 22-42.

12, p. $472-485$

Mackay, J. R., 1958, The Anderson River map-area, N.W.T.: Canada, Geog. Branch, Mem. 5, 137 p.

MacClintock, Paul and Twenhofel, W. H., 1940, Wisconsin glaciation of Newfoundland: Geol. Soc. America Bull,, v. 81, p. 1729-1756.

Mathews, W. H., Fyles, J. G., and Nasmith, H. W., 1970, Postglacial crustal movements in southwestern British Columbia and adjacent Washington state: Canadian Jour Earth Sci., v. 7, p. 690-702.

McCallum, K. J. and Dyck, Willy, 1960, University of Saskatchewan radiocarbon dates II: Am. Jour. Sci. Radiocarbon Supp., v. 2, p. 73-81.

McCallum, K. J. and Wittenberg, J., 1965, University of Saskatchewan radiocarbon dates IV: Radiocarbon, v. 7, p. 229-235.

1968, University of Saskatchewan radiocarbon dates V: Radiocarbon, v. 10, p. $365-378$.

McDonald, B. C., 1969, Glacial and interglacial stratigraphy, Hudson Bay Lowland, in: Hood, P. J. (ed.), Earth science symposium on Hudson Bay: Canada, Geol. Survey Paper 68-53, p. 78-99.

1971, Late Quaternary stratigraphy and deglaciation in Eastern Canada, in: Turekian, K. K. (ed.), The Late Cenozoic Glacial ages: New Haven, Yale Univ. Press., p. 331-353.

McDonald, B. C. and Shilts, W. W., 1971, Quaternary stratigraphy and events, southeastern Quebec: Geol. Soc. America Bull., v. 82, p. 683-698.

Mielke, J. E. and Long, Austin, 1969, Smithsonian Institution radiocarbon measurements V: Radiocarbon, v. 11, p. 163-182.

Milliman, J. D. and Emery, K. O., 1968, Sea levels during the past 25,000 years: Science, v. 162, p. 1121-1123.

Muir, D. M., 1970, The origin and development of retention pools and associated organic structures and plant communities in the western Cordillera and in Newfoundland: M.Sc. thesis, Carleton Univ., Ottawa, Ontario, 229 p. 
Müller, Fritz, 1963, Radiocarbon dates and notes on the climatic and morphological history, in: Axel Heiberg Island research reports: McGill Univ., prelim. rept. 1961-1962, p. 169-172.

1966, Evidence of climatic fluctuations on Axel Heiberg Island, Canadian Arctic Archipelago, in: Fletcher, J. O. (ed.), Symposium on Arctic heat budget and atmospheric circulation Proc.: Memo. RM-5233-NSF, The Rand Corporation, Santa Monica, California, p. 135-156.

Mullineaux, D. R., Waldron, H. H., and Rubin, M., 1965, Stratigraphy and chronology of late interglacial and early Vashon glacial time in the Seattle area, Washington: U.S. Geol. Surv. Bull. 1194-0, 10 p.

Olsson, I. U., 1960, Uppsala natural radiocarbon measurements II: Am. Jour. Sci. Radiocarbon Supp., v. 2, p. 112-128.

Olsson, I. U. and Blake, W., Jr., 1962, Problems of radiocarbon dating of raised beaches, based on experience in Spitsbergen: Norsk geog. tidsskr., v. 18, no. 1-2 (1961-1962), p. 47-64.

Pawluk, S. and Dumanski, J., 1970, Notes from the field tour held in conjunction with the symposium, May 14, 1969, in: Pawluk, S. (ed.), Pedology and Quaternary research: Edmonton, Univ. of Alberta Press, p. 187-218.

Prest, V. K. and Grant, D. R., 1969, Retreat of the last ice sheet from the Maritime Provinces-Gulf of St. Lawrence Region: Canada, Geol. Survey Paper 69-33, 15 p.

Preston, R. S., Person, Elaine, and Deevey, E. S., 1955, Yale natural radiocarbon measurements II: Science, v. 122, p. 954-960.

Rampton, V. N., 1969, Pleistocene geology of the Snag-Klutlan area, southwestern Yukon Territory, Canada: Ph.D. dissert., Univ. of Minnesota, Minneapolis, Minnesota, $237 \mathrm{p}$.

1971a, Quaternary geology, Mackenzie delta and arctic coastal plain, District of Mackenzie, in: Report of activities, Part A, April to October, 1970: Canada, Geol. Survey Paper 71-1, pt. A, p. 173-177.

1971b, Late Quaternary vegetational and climatic history of the SnagKlutlan area, southwestern Yukon Territory, Canada: Geol. Soc. America Bull., v. 82 , p. $959-978$.

Ritchie, J. C., 1969, Absolute pollen frequencies and carbon-14 age of a section of Holocene lake sediment from the Riding Mountain area of Manitoba: Canadian Jour. Bot., v. 47, p. 1345-1349.

Ritchic, J. C. and Lichti-Federovich, Sigrid, 1968: Holocene pollen assemblages from the Tiger Hills, Manitoba: Canadian Jour. Earth Sci., v. 5, p. 873-880.

Ruhe, R. V., 1969, Quaternary landscapes in Iowa: Iowa State Univ. Press, Ames, Iowa, $255 \mathrm{p}$.

Rutter, N. W., 1967, Surficial geology of the Peace River dam and reservoir area, British Columbia, in: Report of activities, Part A, May to October, 1966: Canada, Geol. Survey Paper 67-1, pt. A, p. 87-88.

Quaternary geology of the Peace River Reservoir area (Lake Williston): Canada, Geol. Surv. Bull., ms. in preparation.

van Ryswyk, A. L., 1969, Forest and Alpine soils of south-central British Columbia: Ph.D. dissert., Washington State Univ., Pullman, Washington, 178 p.

Sauvé, Pierre and LaSalle, Pierre, 1968, Notes sur la géologie glaciare de la région de Manic 2: Le naturaliste canadien, v. 95, p. 1293-1300.

Scharpenscel, H. W., Pietig, F., and Tamers, M. A., 1968, Bonn radiocarbon measurements I: Radiocarbon, v. 10, p. 8-28.

Shepard, F. P. and Curray, J. F., 1967, Carbon-14 determinations of sea level changes in stable areas, in: Sears, M. (ed.), Progress in oceanography, v. 4, The Quatcrnary history of the ocean basins: Oxford, Pergamon Press, p. 283-291.

Shilts, W. W., 1969, Pleistocene geology of the Lac Mégantic region, southeastern Québec, Canada: Ph.D. dissert., Syracuse Univ., Syracuse, New York, 154 p.

Skinner, R. G., 1971, Glacial-interglacial stratigraphy, Moose River Basin (42), in: Report of activities, Part A, April to October 1970: Canada, Geol. Survey Paper 71-1, pt. A, p. 179-180.

Souther, J. G., 1970, Volcanism and its relationship to recent crustal movements in the Canadian Cordillera: Canadian Jour. Earth Sci., v. 7, p. 553-568.

Stalker, A. M., 1963, Quaternary stratigraphy in southern Alberta: Canada, Geol. Survey Paper 62-34, 52 p.

1969, Geology and age of the early man site at Taber, Alberta: American Antiquity, v. 34 , p. $425-428$. 
St-Onge, D. A., 1965, La géomorphologie de l'île Ellef Ringnes, Territoires du NordOuest, Canada: Canada, Geog. Branch, Geog. Paper 38, 46 p.

1969, Quaternary geology and geomorphology of the Whitecourt and Tawatinaw area, Alberta, in: Report of activities, Part A: April to October, 1968: Canada, Geol. Survey Paper 69-1, pt. A, p. 217.

1970, Quaternary geology and geomorphology of the Tawatinaw area, Alberta, in: Report of activities, Part A: April to October, 1969: Canada, Geol. Survey Paper 70-1, pt. A, p. 183-184. Bull., in press.

Sutherland Brown, A., 1968, Geology of the Queen Charlotte Islands: British Columbia Dept. of Mines and Petroleum Resources, Bull. 54, 219 p.

1969, Aiyansh lava flow, British Columbia: Canadian Jour. Earth Sci., v. 6, p. 1460-1468.

Terasmae, Jaan and Anderson, T. W., 1970, Hypsithermal range extension of white pine (Pinus strobus L.) in Quebec, Canada: Canadian Jour. Earth Sci., v. 7, p. 406-413.

Terasmae, Jaan and Mirynech, Edward, 1964, Postglacial chronology and the origin of deep lake basins in Prince Edward County, Ontario: Pub. no. 11, Great Lakes Research Div., Univ. of Michigan, Ann Arbor, p. 161-169.

Terasmae, Jaan and Mott, R. J., 1971, Postglacial history and palynology of Sable Island, Nova Scotia: Geoscience and Man (2nd ann. mtg. Proc., Am. Assoc. Stratigraphic Palynologists, Oct. 1969), v. 2.

Vernon, Peter and Hughes, O. L., 1966, Surficial geology of Dawson, Larsen Creek, and Nash Creek map-areas, Yukon Territory: Canada, Geol. Survey Bull. 136, $25 \mathrm{p}$.

Wagner, F. J. E., 1967, Additional radiocarbon dates, Tyrrell Sea area: Maritime Sediments, v. 3, p. 100-104.

Walton, Alan, Trautman, M. A., and Friend, J. P., 1961, Isotopes, Inc. radiocarbon measurements I: Radiocarbon, v. 3, p. 47-59.

Westgate, J. A., Smith, D. G. W., and Nichols, H., 1970, Late Quaternary pyroclastic layers in the Edmonton area, Alberta, in: Pawluk, S. (ed.), Pedology and Quaternary Research: Edmonton, Univ. of Alberta Press, p. 179-186.

White, O. L., 1964, Woodbridge area (Pleistocene): Ontario Dept. Mines, Prelim. Map P-236. 